UNIVERSIDADE DE SÃO PAULO

FACULDADE DE FILOSOFIA, LETRAS E CIÊNCIAS HUMANAS

\author{
PAOLA DE SOUZA MANDALÁ
}

Aspectos fonético-fonológicos e culturais da produção textual de alunos brasileiros e bolivianos de uma escola pública paulistana 
UNIVERSIDADE DE SÃO PAULO

FACULDADE DE FILOSOFIA, LETRAS E CIÊNCIAS HUMANAS

\author{
PAOLA DE SOUZA MANDALÁ
}

\title{
Aspectos fonético-fonológicos e culturais da produção textual de alunos brasileiros e bolivianos de uma escola pública paulistana
}

Dissertação apresentada ao Programa de Filologia e Língua Portuguesa da Faculdade de Filosofia, Letras e Ciências Humanas da Universidade de São Paulo, FFLCH-USP, para a obtenção do grau de Mestre.

Orientadora: Profa. Dra. Rosane de Sá Amado 
Catalogação na Publicação

Mandalá, Paola de Souza.

Aspectos fonético-fonológicos e culturais da produção textual de alunos brasileiros e bolivianos de uma escola pública paulistana / Paola de Souza Mandalá: Orientadora Rosane de Sá Amado. - São Paulo: 2015.

$$
115 \mathrm{p} .
$$

Dissertação apresentada ao Programa de Pós-Graduação em Filologia e Língua Portuguesa da Faculdade de Filosofia, Letras e Ciências Humanas da Universidade de São Paulo para obtenção do Grau de Mestre.

1. Português-Língua Estrangeira. 2. Salas de Aula Mistas. 3. Alunos Imigrantes Bolivianos. 4. Alunos Brasileiros. 5. Fonética. 6. Fonologia.

7. Ethos Discursivo. 8. Português como Segunda Língua (PL2).

9. Língua Espanhola. 10. Ensino Público. 11. Ensino Fundamental. 12. Interculturalidade. 13. Cidade de São Paulo. I. Título. II. Amado, Rosane de Sá, Orientadora.

CDD 469 
Nome: MANDALÁ, Paola de Souza

Título: Aspectos fonético-fonológicos e culturais da produção textual de alunos brasileiros e bolivianos de uma escola pública paulistana

Dissertação apresentada ao Programa de Filologia e Língua Portuguesa da Faculdade de Filosofia, Letras e Ciências Humanas da Universidade de São Paulo, FFLCH-USP, para a obtenção do grau de Mestre.

Aprovado em:

Banca Examinadora

Prof. Dr.: Instituição:

Julgamento: Assinatura:

Prof. Dr.: Instituição:

Julgamento: Assinatura:

Prof. Dr.: Instituição:

Julgamento: Assinatura: 


\section{Dedicatória}

A minha mãe, June, que me ensinou a ler por vias não convencionais e que inspira, por isso, minha vida docente.

Ao meu pai, Paolo, meu exemplo de firmeza e perseverança.

Aos meus irmãos Ricardo e Julio, e às minhas irmãs Daniela, Fabiana e Giovanna, pelo amor com que sempre me cercam.

Aos amigos eternos Andréa, Rogério e Alana, pela maravilhosa experiência de tê-los por perto.

A Cláudio Marques da Silva Neto, educador consciente e amigo.

A Ivonne, amiga sensível neste período da escrita.

A Deus, por cercar-me dessas pessoas amadas. 


\section{$\underline{\text { Agradecimentos }}$}

À professora doutora Rosane de Sá Amado, pela orientação neste trabalho.

Aos profissionais da Escola Municipal Infante Dom Henrique, em especial às professoras Fernanda Zientara, Maria Lúcia, Verônica e Fátima, pela abertura dada à minha presença na escola e com os alunos; às coordenadoras Francis e Milena, pelo igual apoio, respeito pelos alunos, abertura e contato sempre amável; ao diretor Cláudio Marques da Silva Neto, por seguir com rigor a frase dita no nosso primeiro contato: "A escola pública deve sempre estar aberta à pesquisa”.

A todos os alunos que participaram desta pesquisa. 


\section{RESUMO}

Nas escolas públicas da cidade de São Paulo é crescente a quantidade de alunos estrangeiros, destacadamente bolivianos, devido às recentes levas migratórias. Esse fenômeno alterou a conformação de salas de aula, fazendo com que professores precisassem se adaptar ao bilinguismo e ao caráter intercultural da nova sala de aula. A presente pesquisa, objetivando auxiliar o trabalho dos professores, analisa a produção textual de brasileiros e bolivianos, alunos de turmas do $8^{\circ}$ ano do ensino fundamental da Escola Municipal Infante Dom Henrique, com o intuito de apontar e descrever aspectos linguísticos e culturais que possam retratar as especificidades dos grupos formadores dessas turmas mistas. Linguisticamente, identificaram-se os aspectos fonéticofonológicos que interferem na escrita da língua portuguesa dos alunos, compondo uma gramática mínima (VÁZQUEZ, 1999) que revelou, por meio da identificação de inadequações e adequações, o nível de domínio da língua escrita. Culturalmente, com base na identificação do ethos discursivo (MAINGUENEAU, 2008), detectado nas produções escritas sobre tema envolvendo violência e amizade, verificou-se como os alunos dos dois grupos, brasileiros e bolivianos, constroem a imagem de si - o que revelou seus valores e visão de mundo, expondo o significado de seus comportamentos. Assim, associadas, as análises linguística e cultural buscaram orientar a atuação do professor em salas de aula mistas.

Palavras-chave: salas de aula mistas, alunos imigrantes bolivianos, alunos brasileiros, fonética, fonologia, ethos discursivo. 


\section{RESUMEN}

En las escuelas públicas de São Paulo es creciente el número de estudiantes extranjeros, en particular los provenientes de Bolivia, debido a las olas migratorias recientes. Este fenómeno ha cambiado la conformación de las aulas, generando la necesidad en los profesores de adaptarse al bilingüismo y al carácter intercultural de la nueva configuración del aula de clases. En esta investigación, con el objetivo de ayudar a la labor de los profesores, se analiza la producción textual de estudiantes brasileños y estudiantes bolivianos, alumnos de clases de octavo grado de la escuela primaria de la Escuela Infante Dom Henrique, con el fin de señalar y describir los aspectos lingüísticos y culturales que pueden retratar las especificidades de los grupos formadores de tales clases mixtas. Lingüísticamente, se identificaron los aspectos fonético-fonológico que afectan a la escritura en lengua portuguesa de los estudiantes, componiendo una gramática mínima (VAZQUEZ, 1999), lo que reveló, por medio de la identificación de insuficiencias y ajustes, el nivel de dominio del lenguaje escrito. Culturalmente, basado en la identificación del ethos discursivo (MAINGUENEAU, 2008), detectado en las producciones escritas sobre un tema relativo a la violencia y la amistad, se encontró como los estudiantes de ambos grupos, brasileños y bolivianos, construyen la autoimagen - que reveló sus valores y visión del mundo- exponiendo el significado de sus comportamientos. Por lo tanto, asociados, el análisis lingüístico y cultural, buscaron orientar la acción del docente en las aulas mixtas.

Palabras clave: aulas mixtas, estudiantes bolivianos inmigrantes, estudiantes brasileños, fonética, fonología, ethos discursivo. 


\begin{abstract}
In public schools of São Paulo is a growing number of foreign students, notably Bolivia, due to recent migratory waves. This phenomenon has changed the conformation of the classrooms, making the needed teachers adapt to bilingualism and intercultural character of the new classroom. This research, aiming to assist the work of teachers, analyzes the textual production of Brazilian and Bolivian, classes of 8th graders of elementary school of the School Infante Dom Henrique, in order to point out and describe linguistic and cultural aspects that may portray the specificities of forming groups such mixed classes. Linguistically, we identified the phonetic-phonological aspects that affect the writing of Portuguese students, making a minimal grammar (VAZQUEZ, 1999) revealed that, by identifying inadequacies and adjustments, the written language domain level. Culturally, based on the identification of the discursive ethos (MAINGUENEAU, 2008), detected in written productions on theme involving violence and friendship, it was found as students of both groups, Brazilian and Bolivian, build self-image - which revealed its values and world view, exposing the meaning of their behavior. Thus, associated, the linguistic and cultural analysis sought to guide the actions of the teacher in mixed classrooms.
\end{abstract}

Keywords: mixed classrooms, Bolivian immigrants students, Brazilian students, phonetics, phonology, discursive ethos. 


\section{LISTA DE QUADROS}

Quadro 1- Mapa com a distribuição das línguas e etnias pelo território boliviano......................... 15

Quadro 2- Critério linguístico (VÁZQUEZ, 1999). ..................................................................... 26

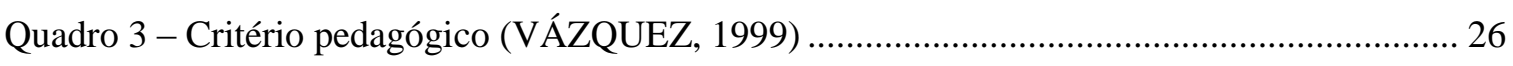

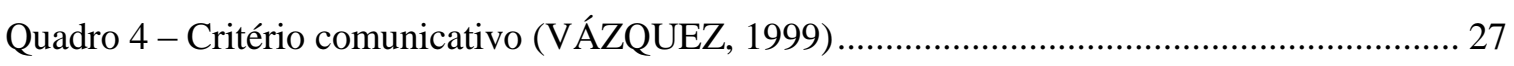

Quadro 5 - Critério pragmático (VÁZQUEZ, 1999).................................................................. 27

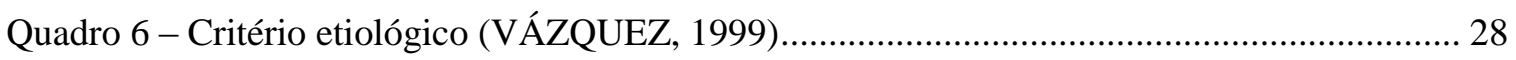

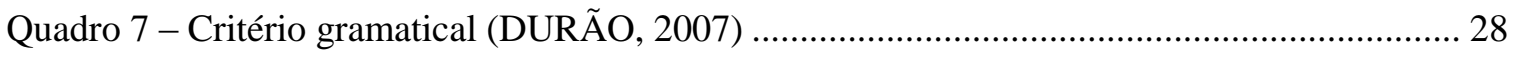

Quadro 8 - Processos psicológicos (SELINKER, 1972) ............................................................ 30

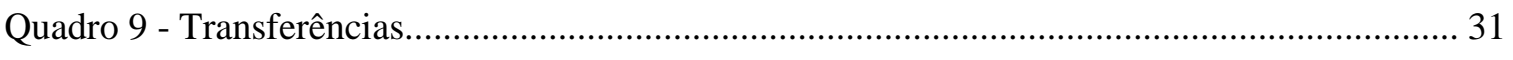

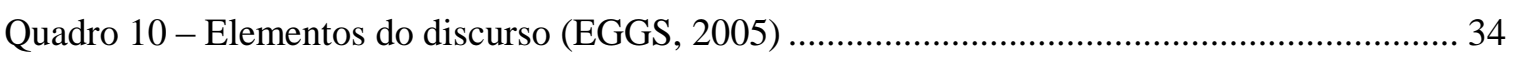

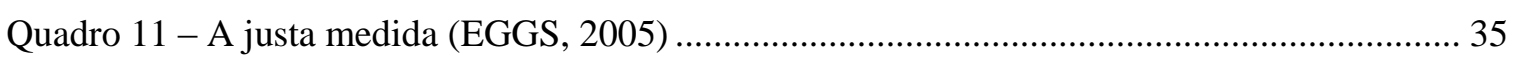

Quadro 12 - Respostas mais frequentes das professoras ao questionário aplicado....................... 39

Quadro 13 - Aspectos referentes a vogais (produção alunos brasileiros) ....................................... 46

Quadro 14 - Aspectos referentes a consoantes (produção alunos brasileiros) .................................47

Quadro 15 - Aspactos referentes a sílaba (produção alunos brasileiros) ........................................ 50

Quadro 16 - Aspectos referentes a acento (produção alunos brasileiros) ..................................... 51

Quadro 17 - Aspectos referentes a vogais (produção alunos bolivianos) ……………………..... 53

Quadro 18 - Aspectos referentes a consoantes (produção alunos bolivianos) ………………….... 54

Quadro 19 - Aspectos referentes a sílaba (produção alunos bolivianos) ………….......................56

Quadro 20 - Aspectos referentes a acento (produção alunos bolivianos) ……………………....... 56

Quadro 21 - Aspectos referentes a vogais (produção alunos bolivianos) ……………………..... 57

Quadro 22 - Aspectos referentes a consoantes (produção alunos bolivianos) ................................ 58

Quadro 23 - Aspectos referentes a sílaba (produção alunos bolivianos) ....................................... 60

Quadro 24 - Aspectos referentes a acento (produção alunos bolivianos) ....................................... 60

Quadro 25 - Aspectos referentes a vogais (produção alunos bolivianos) ...................................... 61

Quadro 26 - Aspectos referentes a consoantes (produção alunos bolivianos) ................................ 62

Quadro 27 - O posicionamento conciliatório em relação às vozes presentes no tema................... 68

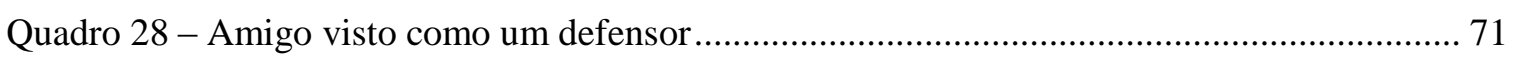

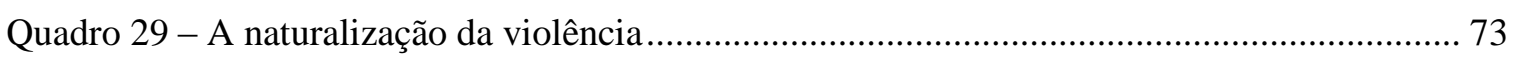

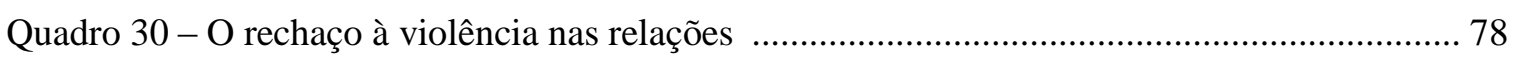

Quadro 31 - O posicionamento único, sem preocupação em conciliar as vozes do tema .............. 80

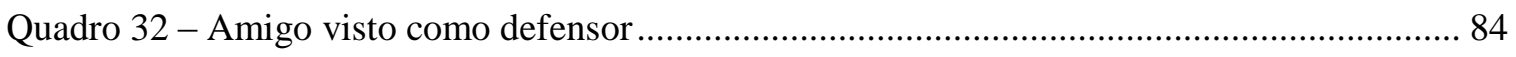

Quadro 33 - A aceitação da violência como forma de reparar injustiça ........................................ 89

Quadro 34 - Gramática mínima da produção escrita dos alunos ................................................... 99 


\section{SUMÁRIO}

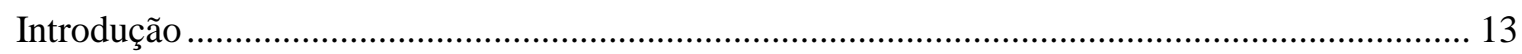

Capítulo 1 - Arcabouço teórico para a realização das análises linguística e cultural..................... 23

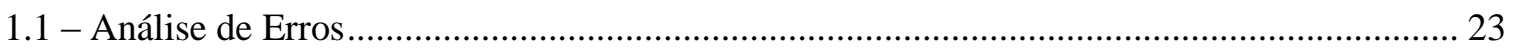

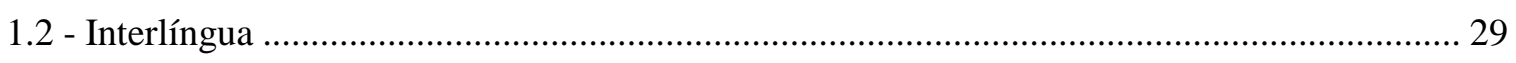

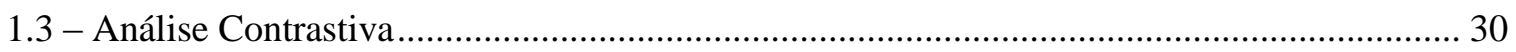

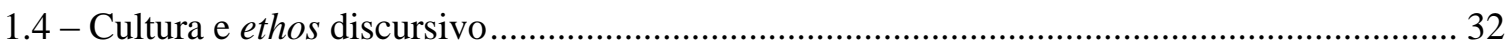

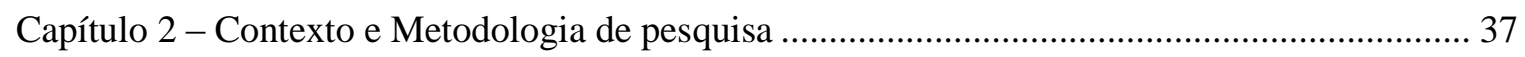

2.1 - Apresentação da Escola Municipal Infante Dom Henrique.................................................... 37

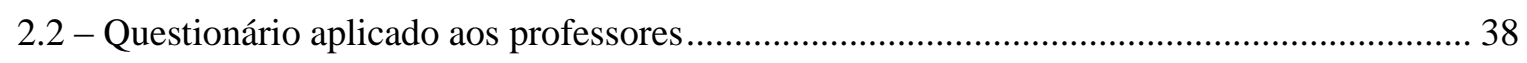

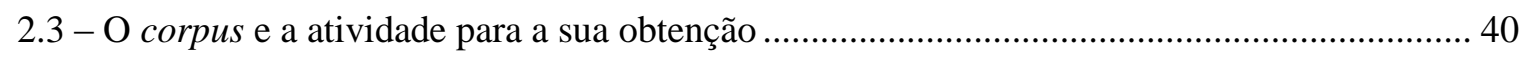

2.4 - Metodologia empregada para a análise dos aspectos linguísticos do corpus ........................ 42

2.5 - Metodologia empregada para a análise dos aspectos culturais do corpus ............................ 44

Capítulo 3 - Análise linguística: aspectos fonético-fonológicos ................................................... 46

3.1 - Análise linguística da produção dos alunos brasileiros ....................................................... 46

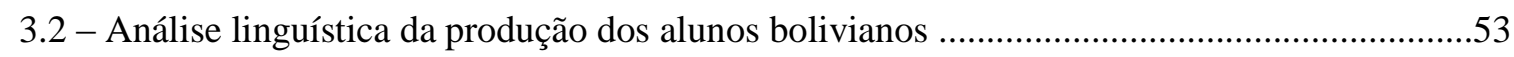

3.2.1 - Análise linguística da produção de alunos bolivianos há 10 anos na escola brasileira...... 53

3.2.2 - Análise linguística da produção de alunos bolivianos há 6 anos na escola brasileira ....... 57

3.2.3 - Análise linguística da produção de alunos bolivianos há 1 ano e meio na escola brasileira61

3.3 - Considerações sobre os dados obtidos das análises linguísticas .......................................... 64

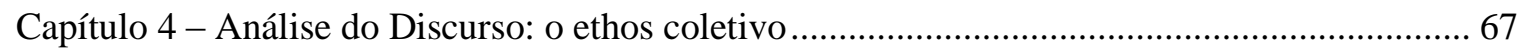

4.1 - Os ethe identificados no discurso escrito dos alunos brasileiros ......................................... 68

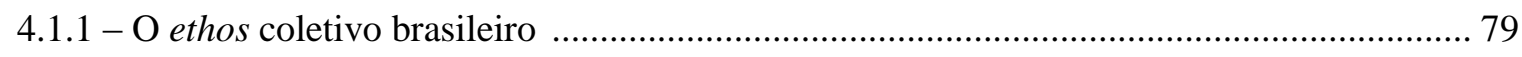

4.2 - Os ethe identificados no discurso escrito dos alunos bolivianos ......................................... 79

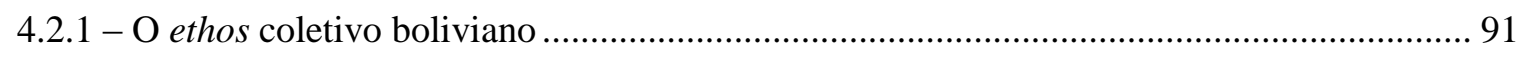

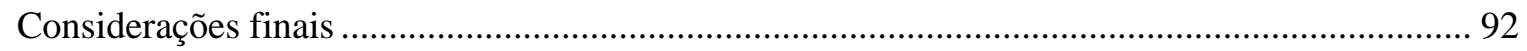

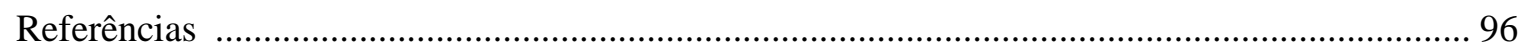

ANEXO 1 - Mapa com a distribuição das línguas e etnias pelo território boliviano ...................... 99 
ANEXO 2 - Transcrição integral dos textos do corpus .

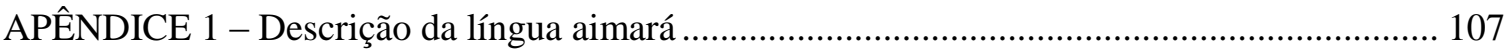

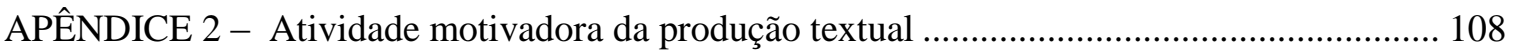

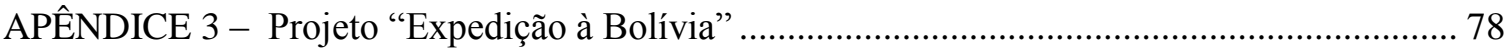




\section{INTRODUÇÃO}

A presente pesquisa analisa a produção de textos escritos por brasileiros e bolivianos, alunos de turmas do $8^{\circ}$ ano do ensino fundamental da uma escola pública municipal paulistana, com o objetivo de apontar e descrever aspectos linguísticos e culturais que possam retratar essas turmas mistas. Linguisticamente, buscou-se identificar o nível de domínio da competência escrita da língua portuguesa por bolivianos e brasileiros, circunscrito a aspectos fonético-fonológicos. Culturalmente, com base no discurso apresentado nas produções escritas sobre tema envolvendo violência e amizade, a análise procurou verificar como os alunos dos dois grupos, brasileiros e bolivianos, constroem a imagem de si. Associados, os aspectos linguístico e cultural oferecem ao professor que atua em salas de aula mistas instrumentos que orientam seu trabalho na seleção dos recursos de que se utiliza para ensinar língua portuguesa e proceder de forma integradora em contextos bilíngues e interculturais, os quais são cada vez mais presentes na atualidade escolar da cidade de São Paulo, cuja maior e mais recorrente representação são as salas de aula que congregam estudantes brasileiros e bolivianos.

Nas escolas públicas da cidade de São Paulo há 3.314 alunos estrangeiros, de acordo com dado de 2013 fornecido pela rede municipal de ensino ${ }^{1}$. Destes, 2.077 são bolivianos, o que os faz maioria entre os alunos imigrantes, tornando as salas de aula o retrato das comunidades bilíngues em que as escolas estão inseridas. A predominância se dá nas zonas norte e central da cidade. Bairros como Pari, Canindé, Casa Verde, Vila Maria, Brás e Bom Retiro concentram a população imigrante boliviana que, desde o final dos anos 1980 e início dos 1990, passou a considerar o Brasil como destino de migração, momento em que a Argentina - primeira e principal opção - passava por grave crise financeira.

Passadas mais de duas décadas do início desse fluxo migratório, o ingresso de bolivianos ao Brasil continua e é crescente ${ }^{2}$, sobretudo à cidade de São Paulo, pela

\footnotetext{
1 Dados obtidos da revista Carta Fundamental, edição on-line número 53, de novembro de 2013. Disponível em http://www.cartafundamental.com.br/single/show/61, último acesso em 24/06/2014

${ }^{2}$ Os números variam a depender da fonte. Os fornecidos por órgãos oficiais são menores, e os fornecidos por entidades de apoio são maiores. Isso pode ocorrer devido ao alto número de imigrantes bolivianos indocumentados que, por essa razão, não recorrem a órgãos oficiais, mas às já citadas entidades de apoio. Assim, o Censo 2010 registrou 17.970 residentes bolivianos na capital paulista, e a Polícia Federal estima cerca de 32 mil bolivianos em todo o território brasileiro; o Consulado Boliviano em São Paulo calcula mais de 100 mil; associações de bolivianos contabilizam 350 mil em todo o Brasil, sendo $75 \%$ residentes na cidade de São Paulo (http://bolivianosnobrasil.blogspot.com.br/); a Pastoral do Imigrante acredita que,
} 
concentração de oferta de trabalho na área têxtil, onde os adultos são empregados e, em sua maioria, sub-remunerados. Os filhos desses imigrantes são os que integram os já citados 2.077 bolivianos presentes na rede pública municipal de ensino, os quais ingressam na escola em diferentes etapas da escolarização, havendo desde os que iniciam o processo de letramento nas escolas brasileiras até os que concluem, no Brasil, o processo iniciado na escola boliviana. Essa descrição passa por casos em que o aluno apresenta percurso de letramento entrecortado por idas e vindas de um país ao outro, motivado pelos deslocamentos da família, o que resulta em mescla de experiências escolares, ora em português, ora em espanhol. Há inclusive alunos bolivianos que iniciam a vida escolar no Brasil, mas que permanecem em regime de contato quase exclusivo com a família ou grupo imigrante, fato que tem como consequência o domínio restrito da língua portuguesa, o que compromete sua interação nessa língua, quer seja no microcosmo escolar ou nos momentos em que se encontra em contextos sociais que extrapolam os já citados grupos familiar ou imigrante.

De acordo com Jung (1997, p. 24), entende-se interação como "padrões de alocação de direitos e obrigações interacionais entre todos os membros que estão em conjunto, desenvolvendo uma situação social". O domínio da língua oficial é um dos fatores que influenciam positiva ou negativamente a interação, tornando compreensíveis ou incompreensíveis os direitos e as obrigações. Os alunos bolivianos, como mencionado, apresentam diferentes níveis de domínio da língua portuguesa ao ingressarem na escola brasileira, consequentemente, variados níveis de interação. Essa diversidade apresenta-se, muitas vezes, em uma única sala de aula. O professor que tem diante de si a tarefa de ensinar língua portuguesa a uma turma que congrega alunos brasileiros e bolivianos, geralmente, passou por formação acadêmica monolinguista, a qual desconsidera os contextos bilíngues em que estão inseridas diversas escolas brasileiras, muitas delas em áreas de fronteira ou de minoria linguística, como é o caso das escolas paulistanas dos bairros habitados por imigrantes bolivianos. Há que se considerar que na Bolívia há quatro línguas oficiais, sendo elas o espanhol (presente em todas as regiões devido à colonização espanhola e ao ensino formal nessa língua), o quéchua (com predomínio nas zonas central e sul andinas, referentes ao departamento de Potosi, ao departamento de Cochabamba e à parte oriental do departamento de La

em São Paulo, os números estejam por volta $\quad$ dos 60
mil (http://www.cealag.com.br/Trabalhos/NosDoCentro/Nos do_Centro.pdf); Gordonava (2009) aponta 300 mil em todo o Brasil. 
Paz - local de origem dos imigrantes bolivianos do Brasil), o aimará (com predomínio no extremo oeste andino, referente ao departamento de Oruro e à parte oeste do departamento de La Paz - outro lugar de origem dos imigrantes bolivianos do Brasil) e o guarani (com predomínio nos departamentos do sudeste da Bolívia, como Santa Cruz, Chuquisaca e Tarija). Abaixo, o mapa com a distribuição das línguas e etnias bolivianas ${ }^{3}$ :

Quadro 1 - Mapa com a distribuição das línguas e etnias pelo território boliviano

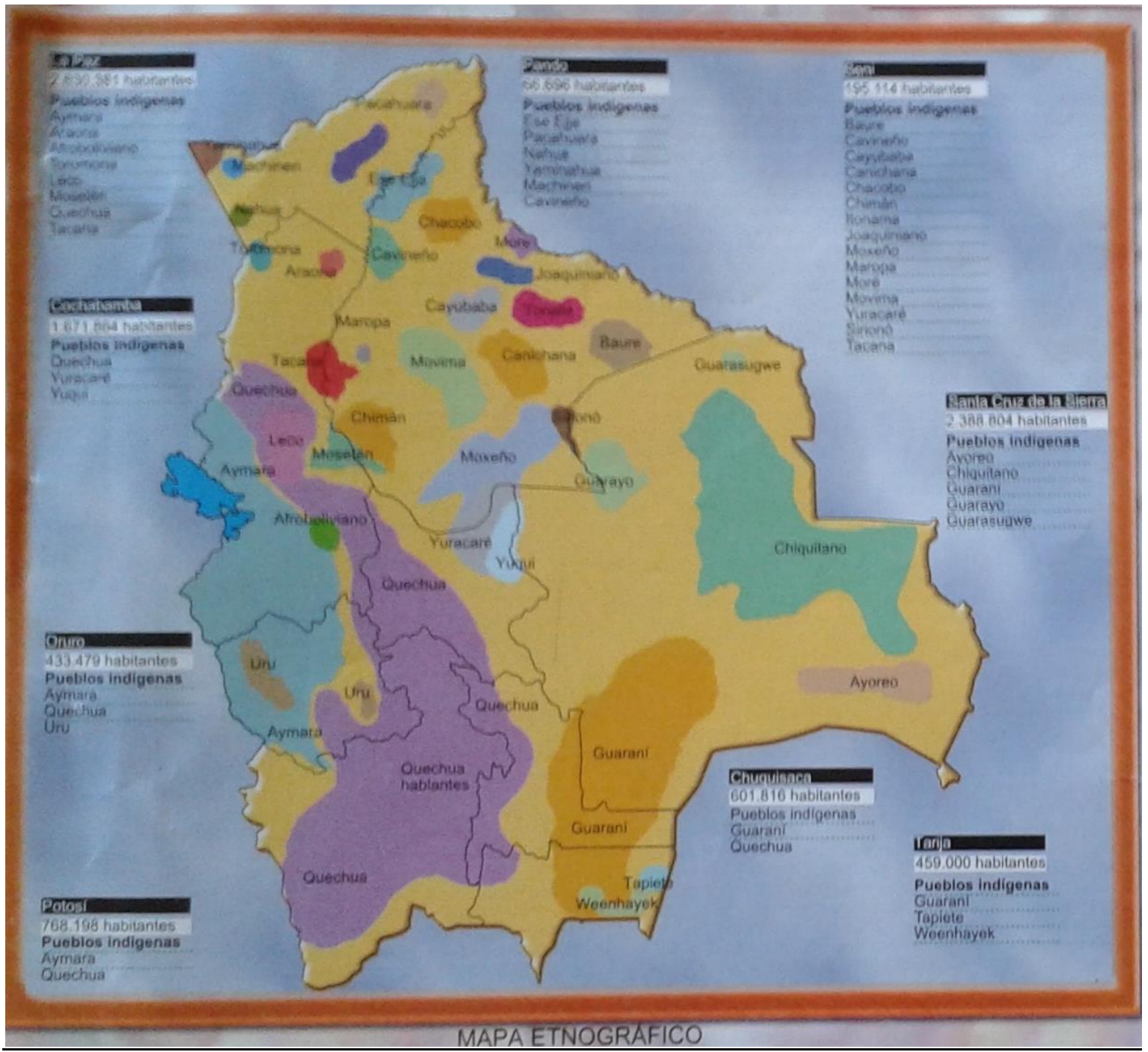

Portanto, nas citadas salas de aula mistas, há um ambiente bilíngue, e por vezes multilíngue, frente ao qual o professor geralmente desenvolve sua forma de ação capacitando-se por meio da experiência que vai adquirindo nesse contexto, ou ignorando as especificidades linguísticas que se apresentam. Assim, orientou-se a

\footnotetext{
${ }^{3} \mathrm{O}$ mapa completo pode ser visto no ANEXO 1.
} 
presente pesquisa a fornecer análises que explicitam as especificidades linguísticas com as quais o professor convive na sua prática diária, e que não se encaixam no discurso monolíngue. Objetivou-se constituir, desse modo, uma gramática mínima que evidencia o nível de domínio da competência escrita em língua portuguesa por alunos brasileiros e bolivianos, relativo a aspectos fonético-fonológicos, estabelecendo as diferenças que possam caracterizar as necessidades e habilidades de cada grupo. $\mathrm{O}$ conceito de uma gramática mínima foi emprestado de Graciela Vázquez (1999), a qual trata de uma gramática mínima de erros, cuja função é reunir as principais e recorrentes incorreções dos alunos, estabelecendo assim seu nível de domínio linguístico, o que orienta o trabalho do professor nas intervenções pedagógicas que irá realizar. A autora defende que, para o processo de aprendizagem, é importante "la creación de gramáticas mínimas de errores. Es decir, gramáticas a la medida de los grupos meta" (VÁZQUEZ, 1999, p.89). No entanto, apresentar os erros e analisá-los não corresponde a apresentar o nível de domínio da língua, pois haveria aí uma série de soluções linguísticas ignoradas que representam verdadeiramente o domínio. Portanto, optou-se por acrescentar à gramática mínima de erros da autora a "identificação de estruturas utilizadas corretamente", de acordo com García Solis (2005). Desse modo, o que se vê das produções indica o nível de domínio da competência escrita da língua portuguesa, e não apenas o nível de carência linguística dos alunos.

A opção por tratar dos aspectos fonético-fonológicos justifica-se por tais elementos poderem resultar em transferência na realização gráfica da língua, tanto para os brasileiros lusofalantes quanto para os bolivianos hispanofalantes. De acordo com os Parâmetros Curriculares Nacionais (doravante PCNs) sobre Língua Portuguesa:

[...] para aprender a ler e a escrever, o aluno precisa construir um conhecimento de natureza conceitual: ele precisa compreender não só o que a escrita representa, mas também de que forma ela representa graficamente a linguagem. (PCNs, Língua Portuguesa, 2000, p. 20)

Assim, analisar os elementos fonético-fonológicos, identificáveis nas produções textuais dos alunos, significa observar como a fala pode ser transferida para a escrita, ou seja, como pode modificar o aspecto formal da língua. Para o aprendiz não nativo, como é o caso dos estudantes bolivianos, essa transferência constitui-se no que, geralmente, mais se nota a respeito do seu domínio da língua alvo, pois pode estar carregada de marcas da sua língua materna. Portanto, a partir da elaboração de uma gramática 
mínima contendo os aspectos fonético-fonológicos que caracterizam a produção escrita de alunos brasileiros e de alunos bolivianos, é possível estabelecer qual tipo de atuação didático-pedagógica é necessária para cada grupo.

A escolha por estudar as produções textuais de alunos do $8^{\circ}$ ano do ensino fundamental deveu-se ao fato de, nesse estágio, o aluno já ter passado pelas séries iniciais, em que os objetivos no ensino de língua portuguesa, de acordo com os PCNs, estão relacionados a desenvolver as habilidades linguísticas para "conhecer" e "compreender" o mundo, bem como "perceber-se integrante" dele e "posicionar-se de maneira crítica" a seu respeito. Ou seja, o estudo da língua relaciona-se à exploração do universo concreto. Assim, no $8^{\circ}$ ano, o aluno encontra-se em estágio intermediário e, portanto, preparatório para cursar as séries do ensino médio, em que o estudo da língua relaciona-se a abstrações sobre o universo concreto construído linguisticamente nos anos anteriores, quer dizer, "utilizar-se das linguagens como meio de expressão, informação e comunicação em situações intersubjetivas, que exijam graus de distanciamento e reflexão sobre os contextos e estatutos de interlocutores" (2000: 10), de acordo com os PCNs para Língua Portuguesa do ensino médio. Desse modo, estudar as produções de alunos no $8^{\circ}$ ano possibilita verificar seu aprendizado num momento de transição para um nível mais complexo, durante o qual será possível realizar intervenções ou trabalhar para desenvolver potencialidades. Nesse sentido, o foco nos aspectos fonético-fonológicos de textos de alunos do fim do ensino fundamental objetiva verificar como a fala pode estar interferindo na representação gráfica da linguagem, representação esta que não deve constituir-se como empecilho para as reflexões a serem realizadas nas séries posteriores.

Sobre a opção pela análise da língua escrita, a justificativa encontra-se na relevância do domínio dessa competência não só para a promoção escolar dos estudantes, como também para a social.

Entendendo a competência escrita como a união de codificação e descodificação gráfica de uma determinada língua, pois "quando se está escrevendo é obrigatória a leitura" (SCLIAR-CABRAL, 2003, p.20), são diversas as situações em que o domínio dessa competência é necessário. Em contexto escolar, possibilita a recepção ou produção dos diversos discursos que se apresentam em forma textual, como comunicações internas e externas, material didático, tarefas, livros, regulamentos; e, em contexto social, propicia acesso à decodificação ou codificação de mensagens, placas de rua e de comércio, embalagens de produtos, receituário médico, livros, documentos, 
entre outros. Tanto para nativos quanto para estrangeiros, o domínio da competência escrita da língua pode conferir acesso a âmbitos letrados, não somente os cotidianos apontados, mas também aqueles da esfera oficial, circunscritos geralmente à documentações, registros, contratos. Encontramos, ainda em Scliar-Cabral (2003), a distinção entre a relevância social do domínio da modalidade oral e escrita da língua:

Tanto a modalidade oral quanto a escrita são meios de comunicação verbal. Contudo, enquanto a modalidade oral deve ser considerada como um dos meios que possibilita a sobrevivência de indivíduo e da espécie, obedecendo a um imperativo social e cognitivo, o desconhecimento da modalidade escrita não condena nenhum indivíduo ou grupo à extinção física, embora nas sociedades letradas coexista com a exclusão e/ou ser explorado e com limites para o exercício da cidadania. (CABRAL, 2003, p. 29)

O texto dos PCNs sobre língua portuguesa corrobora a afirmação de Cabral:

O domínio da língua, oral e escrita, é fundamental para a participação social efetiva, pois é por meio dela que o homem se comunica, tem acesso à informação, expressa e defende pontos de vista, partilha ou constrói visões de mundo, produz conhecimento. Por isso, ao ensinála, a escola tem a responsabilidade de garantir a todos os seus alunos o acesso aos saberes linguísticos, necessários para o exercício da cidadania, direito inalienável de todos. (PCNs, Língua Portuguesa, p. 15)

Para os grupos de minoria linguística, como é o caso dos bolivianos que vivem em São Paulo, a promoção social que o domínio da competência escrita da língua portuguesa faculta pode definir a garantia ou não de direitos básicos, como acesso à saúde, direitos do trabalhador, moradia, legalização de documentos, além de maior possibilidade de se organizar por meio de associações que se comuniquem formalmente com organismos brasileiros governamentais ou não. Vieira (2009), ao estudar o contato de imigrantes bolivianos adultos com o ensino formal da língua portuguesa, constatou que, a carga horária de trabalho excessiva reduz a possibilidade de dedicação ao estudo formal de língua portuguesa. Além disso, a organização da forma de trabalho coloca-os em convívio diário e quase que exclusivo com membros do mesmo grupo imigrante, o que oferece poucas oportunidades de contato com a língua portuguesa, fossilizando a interlíngua $^{4}$ que desenvolvem para se comunicarem com os brasileiros.

\footnotetext{
${ }^{4}$ Trataremos de Interlíngua e Fossilização no capítulo 1, referente ao arcabouço teórico, na p. 28.
} 
O que se verifica, muitas vezes, é que esses estrangeiros se congregam em grupos compostos por seus próprios familiares ou por falantes de espanhol da mesma ou de outra nacionalidade. Tais grupos, que se identificam pela língua materna comum, pelas necessidades e costumes compartilhados, de alguma maneira se satisfazem com o aprendizado de determinadas estruturas elementares da língua portuguesa que lhes permite uma convivência relativamente cômoda, ou pelo menos possível, com a comunidade paulistana. (VIEIRA, 2009, p. 98)

Essa situação faz com que a oportunidade e a responsabilidade de contato formal com a língua portuguesa sejam depositadas na geração que tem condições de se escolarizar: os filhos, pois são eles os que, não estando absorvidos pelo universo do trabalho, podem transcender à situação dos pais com relação ao letramento e aos acessos facultados por ele.

Assim, ao realizar análise da produção escrita de alunos bolivianos em comparação com a de brasileiros, a pesquisa oferece ao professor elementos que possibilitam a identificação das especificidades linguísticas de cada grupo, orientando a seleção dos recursos de que irá se utilizar para o ensino na língua portuguesa em sala de aula mista, noção que evita a negligência das necessidades ou potencialidades dos elementos constitutivos dessa conjunção.

O retrato de uma sala de aula mista não pode deter-se nos aspectos linguísticos de seus integrantes. Em contextos bilíngues, a análise linguística não é suficiente para a caracterização dos elementos constitutivos das especificidades presentes. Segundo Jung (1997), a sala de aula mista:

[...] é analisada como um microcontexto no qual se redefinem os papéis e as relações sociais já definidos na sociedade, afinal, os sujeitos, quando entram na escola, não deixam do lado de fora aquele conjunto de fatores individuais e sociais que os distinguem como indivíduos dotados de vontade, sujeitos em um determinado tempo e lugar. (JUNG, 1997, p. 34)

A identificação dos elementos culturais pode apontar o significado dos comportamentos, do que se expressa e do que não se expressa. Assim, realizou-se, além da análise linguística, a análise do discurso dos alunos bolivianos e dos brasileiros, buscando revelar o que caracteriza a visão de mundo expressa nas produções, relativa a questões que interferem no dia a dia dos alunos, a saber, amizade e violência. Amizade, pelo fato de os estudantes estabelecerem vínculos que promovem a formação de identidades, contato com apego e desapego, elementos próprios da adolescência com os 
quais se convive em ambiente escolar. Violência, por também estar presente no ambiente escolar - sobretudo no caso dos alunos bolivianos, os quais, de acordo com depoimentos de pais, alunos, diretor, coordenadoras e professores da escola estudada, são alvo de atos dessa natureza.

O objetivo de identificar e analisar os elementos culturais do discurso dos alunos foi o de explorar aquilo que as professoras da escola apontaram como o que caracterizava os alunos bolivianos: silêncio, timidez, disciplina, e a contrapartida com relação aos alunos brasileiros. Dessa forma, pôde-se refletir sobre as marcas culturais presentes nos textos, as quais elucidaram comportamentos e visão de mundo dos alunos. A partir dos levantamentos, foi possível verificar que os jovens atuam de acordo com os valores e visão de mundo prevalentes em sua sociedade: os alunos brasileiros, conforme os elementos que se veem na sociedade brasileira; e os alunos bolivianos, apesar de viverem em São Paulo, agem de acordo com valores típicos da sociedade boliviana, devido sobretudo à força participativa e formadora da família.

Considerando esses apontamentos e compreendendo o universo intercultural de sua sala de aula mista, o professor pode interpretar os comportamentos dos alunos, atuando interculturalmente também. A partir da identificação das especificidades linguísticas dos grupos presentes o professor tem meios para driblar sua formação monolíngue, agindo para viabilizar o aprendizado do português tanto como língua materna quanto como segunda língua. O resultado é uma diferenciação na ação pedagógica, que não negligencia as particularidades dos seres, que deixa claro, por exemplo, ao aluno imigrante que não se trata de trocar sua(s) língua(s) materna(s) pela língua portuguesa dominante, mas que ele pode se ver e ser visto como bilíngue.

As análises linguística e cultural que aqui se apresentam oferecem uma contribuição para esse caminho, e se inserem como continuação das pesquisas realizadas sobre a população imigrante boliviana da Profa. Dra. Maria Eta Vieira (2009), cuja tese de doutorado versa sobre ensino e aprendizagem de português como língua estrangeira para essa população; e da Mestre Giovanna Modé Magalhães (2010), cuja dissertação de mestrado é dedicada a analisar o acesso de imigrantes bolivianos às escolas públicas de São Paulo, sob a ótica da universalização dos Direitos Humanos às populações migrantes.

Assim, para a elaboração do quadro linguístico e cultural de turmas que congregam brasileiros e bolivianos, os capítulos da presente dissertação foram organizados da seguinte maneira: 
No capítulo 1, realizou-se a apresentação dos conceitos que formam o arcabouço teórico condutor das análises linguística e cultural. Trata-se, para a análise linguística, das contribuições de Corder (1967), sobre a Análise de Erros, e de Selinker (1972), sobre Interlíngua, além dos conceitos de Vázquez (1999) para a elaboração de gramática mínima de erros, e de García Solis (2005), sobre a inclusão do não erro como indicador relevante do real nível de competência linguística dos alunos.

O estudo dos aspectos culturais das produções teve como norteadores os conceitos de Amossy (2005), Maingueneau (2008, 2005) e Eggs (2005) sobre o ethos discursivo, o qual revela a construção da imagem de si pelo enunciador do discurso. Ao verificar as imagens construídas pelos enunciadores brasileiros e bolivianos, é possível estabelecer a imagem coletiva de cada grupo, ou seja, o ethos coletivo brasileiro e o ethos coletivo boliviano.

O capítulo 2 é destinado à exposição do contexto de pesquisa e da metodologia empregada. Como contexto de pesquisa, é apresentada a Escola Municipal Infante D. Henrique, localizada no bairro do Canindé, zona norte da cidade de São Paulo, a qual possui salas de aula mistas, de brasileiros e imigrantes, com particular presença de bolivianos. Três dessas turmas mistas, os $8^{\circ} \mathrm{s}$ anos $\mathrm{A}, \mathrm{B}$ e $\mathrm{C}$, foram os que forneceram os textos formadores do corpus analisado nesta pesquisa.

Como metodologia de pesquisa, aplicou-se questionário aos professores sobre sua experiência com ensino em salas de aula mistas. Dos questionários extraiu-se a pergunta da pesquisa, a saber:

Quais são as características linguísticas e culturais que diferenciam ou aproximam alunos bolivianos e brasileiros em uma sala de aula mista?

Para procurar respondê-la, aplicou-se atividade escrita para as três turmas mistas de $8^{\circ}$ ano, sobre tema envolvendo amizade e violência. Seguiu-se à análise das produções para, no nível linguístico, verificar o estágio de domínio da competência escrita em língua portuguesa dos brasileiros e dos bolivianos; e, referente aos aspectos culturais, delinear, por meio da identificação do ethos coletivo, os valores e visão de mundo dos alunos. Os dados foram comparados de modo a caracterizar as especificidades de cada grupo.

No capítulo 3, é exibida a análise linguística dos textos dos alunos brasileiros e bolivianos, elaborando-se assim uma gramática mínima referente às produções de cada grupo, considerando para isso tanto as estruturas com incorreções, quanto aquelas 
construídas de modo satisfatório, o que resultou na verificação do domínio da competência escrita dos alunos brasileiros e bolivianos em nível fonético-fonológico.

No capítulo 4, para tratar das características culturais de brasileiros e bolivianos, realizou-se a análise do discurso das produções textuais, o que se deu pela identificação do ethos construído pelos enunciadores. Os ethe mais recorrentes constituíram o ethos coletivo de cada grupo.

Nas considerações finais são apresentadas reflexões sobre as características identificadas e analisadas, bem como sua importância para auxiliar o trabalho do professor de língua portuguesa atuante em sala de aula mista. 


\section{CAPÍTULO 1. ARCABOUÇO TEÓRICO PARA A REALIZAÇÃO DAS ANÁLISES LINGUÍSTICA E CULTURAL}

Conforme apresentado na introdução, a presente pesquisa tem como objetivo identificar os elementos linguísticos e culturais presentes em textos de alunos brasileiros e bolivianos de três turmas de $8^{\circ}$ ano do ensino fundamental II que, analisados, podem fornecer ao professor, sobretudo o de língua portuguesa, informações e reflexões sobre as características dessas turmas mistas. Tais informações e reflexões são, linguisticamente, as relativas às dificuldades e facilidades desses lusofalantes e hispanofalantes na aquisição da língua portuguesa; e, culturalmente, as relativas a comportamento e visão de mundo, depreensíveis do discurso adotado por eles nos textos do corpus, que podem orientar o professor sobre as ações de que lança mão para fomentar a integração e a tolerância intercultural entre os seus alunos.

O presente capítulo apresenta o quadro teórico utilizado para analisar as produções textuais, o qual considera, para reflexões linguísticas, os modelos da área da Linguística Contrastiva, a saber, Análise de Erros (CORDER, 1967) e Interlíngua (SELINKER, 1972), além do próprio modelo de Análise Contrastiva; e, para as reflexões culturais, a definição de cultura (TROUCHE, 2005) e os conceitos sobre ethos discursivo (AMOSSY, 2005; MAINGUENEAU, 2008, 2005; EGGS, 2005).

\subsection{Análise de Erros}

As análises linguísticas, circunscritas nesta pesquisa a aspectos fonéticofonológicos das produções textuais, realizaram-se sob o modelo de Análise de Erros (CORDER, 1967), por esta considerar o erro do aprendiz uma fonte de informações sobre seu raciocínio, estratégias e estágio de aprendizado. De acordo com o autor:

Os erros do aluno, então, fornecem provas do sistema da linguagem que ele está usando (ou seja, aprendeu) em um determinado ponto no curso (e deve ser repetido que ele está usando algum sistema, embora não seja ainda o sistema correto). Eles são significativos de três formas diferentes. Primeiro, para o professor, na medida em que lhe diz, ao empreender uma análise sistemática, o quão longe em direção ao objetivo o aluno avançou e, consequentemente, o que resta para ele aprender. Em segundo lugar, os erros fornecem ao pesquisador as evidências de como a linguagem é aprendida ou adquirida, que estratégias ou procedimentos o aluno está empregando em sua descoberta da linguagem. Em terceiro lugar (e, em certo sentido, esse 
é o seu aspecto mais importante) que os erros 'são indispensáveis para o próprio aluno, porque podemos considerar a realização de erros como um dispositivo que o aluno utiliza para aprender. É uma forma que o aluno tem de testar suas hipóteses sobre a natureza da língua que está aprendendo. (CORDER, 1967, p. 167, tradução nossa) ${ }^{5}$

Essa concepção sobre o erro foi desenvolvida a partir das teorias de Chomsky sobre aquisição de línguas. Tais teorias eram contrárias ao Condutivismo, corrente vigente na época - primeira metade do século XX - que afirmava que as línguas se aprendiam por meio da criação de hábitos, por repetição. Para Chomsky, a aquisição das línguas se dava por meio da geração de regras, pelo aprendiz, que o fazia de acordo com as regras de sua Gramática Universal (doravante GU). De acordo com a GU, conceito também de Chomsky, existem regras universais linguísticas, as quais, por exemplo, fixam parâmetros morfológicos, sintáticos, fonológicos para a organização das línguas. Como um exemplo para parâmetros morfológicos, há a tendência a diferenciar as classes morfológicas por meio de indicadores (morfemas, partículas que se acrescentam às palavras) exclusivos ou recorrentes para cada classe gramatical. $\mathrm{O}$ mesmo é definido para as distinções sintáticas, fonético-fonológicas, semânticas, padrões de formalidade ou informalidade, e assim por diante. A aquisição de línguas, portanto, estaria condicionada à relação que o aprendiz/utente faz entre a GU e o input que recebe da língua, inferindo as regras, as quais são o resultado da hierarquização dos parâmetros que detecta.

O modelo de Análise de Erros é concebido a partir desses conceitos, pois, tratando os erros como pertencentes a um sistema linguístico transitório, aproxima as estratégias de aquisição dos aprendizes de uma segunda língua (doravante L2) à de crianças adquirindo sua língua materna (doravante LM), afirmando que ambos passam por circunstâncias similares.

\footnotetext{
5 A learner's errors, then, provide evidence of the system of the language that he is using (i.e. has learned) at a particular point in the course (and it must be repeated that he is using some system, although it is not yet the right system). They are significant in three different ways. First to the teacher, in that they tell him, if he undertakes a systematic analysis, how far towards the goal the learner has progressed and, consequently, what remains for him to learn. Second, they provide to the researcher evidence of how language is learned or acquired, what strategies or procedures the learner is employing in his discovery of the language. Thirdly (and in a sense this is their most important aspect) they are indispensable to the learner himself, because we can regard the making of errors as a device the learner uses in order to learn. It is a way the learner has of testing his hypotheses about the nature of the language he is learning. (CORDER, 1967, p. 167)
} 
A produção de erros, então, é uma estratégia utilizada tanto por crianças ao adquirem sua língua materna, quanto por pessoas que aprendem uma segunda língua. (CORDER, 1967, p. 167, tradução nossa) ${ }^{6}$

Essa visão sobre o processo de aquisição de L2 revisou a forma como se tratava o erro até então. Se antes, dentro do Condutivismo, o erro deveria ser evitado visando à construção de hábitos linguísticos normatizados; após a consideração da GU e da teoria sobre aquisição de línguas, o erro passou a ser visto como um indicador do estágio em que se encontrava o aprendiz durante o processo de aquisição da L2, pois, para a geração das regras, haveria tentativas que poderiam resultar em matizes entre o acerto e o erro. Tais matizes deveriam ser levados em consideração para determinar se o aprendiz de L2 estaria utilizando as regras da sua língua materna para a estruturação da gramática da nova língua, ou se estaria deduzindo regras dessa nova língua a partir de observações equivocadas de seu sistema, entre outras estratégias. A identificação de tais estratégias poderia indicar as áreas de maior dificuldade de aprendizado.

Para Corder, os erros estariam categorizados em sistemáticos e não sistemáticos. Os primeiros são aqueles que comprometem a competência linguística e que demonstram conhecimento deficiente da língua alvo; os últimos, não sistemáticos, são motivados por cansaço ou lapso mental, facilmente corrigíveis pelos falantes, sendo indicativos de problemas de desempenho, não de domínio do sistema da língua alvo. São, portanto, os erros sistemáticos aqueles que revelam o estado da língua dos falantes, e, a partir da seleção e análise desses erros, é possível produzir materiais didáticos mais apropriados às necessidades dos aprendizes, bem como orientar as ações pedagógicas dos professores no mesmo sentido.

A presente pesquisa utiliza-se deste conceito não só para analisar a produção dos alunos bolivianos hispanofalantes na aquisição da língua portuguesa como L2, mas também para tratar das produções dos alunos brasileiros aprendizes de língua portuguesa como LM, pois, como visto, a Análise de Erros (doravante AE) contribui para evidenciar as estratégias de aprendizado do aluno, verificando os erros sistemáticos e os não sistemáticos, independentemente de o objeto de estudo ser a LM ou uma L2. Vale lembrar que a AE é teoria utilizada em outras áreas de estudo, como a geografia, a matemática, a biologia, justamente por tratar do engenho dos aprendizes para a

\footnotetext{
${ }^{6}$ The making of errors then is a strategy employed both by children acquiring their mother-tongue and by those learning a second language. (Corder, 1967, p. 167)
} 
aquisição do conhecimento, além de ter sido desenvolvida inicialmente para as observações sobre os erros de aprendizes de LM. Assim, ao analisar as produções dos alunos brasileiros e dos bolivianos de acordo com o mesmo critério, traça-se o perfil do estágio de aquisição da língua portuguesa dos alunos presentes nas turmas, a partir da identificação dos erros sistemáticos e dos não sistemáticos.

São variados os critérios para a classificação dos erros, já que o modelo de AE foi desenvolvido por outros autores além de Corder. Assim, a AE, como um todo, fornece os critérios linguístico, pedagógico, comunicativo, pragmático, etiológico e gramatical. Em um volume dedicado a AE, Vázquez (1999) traz sistematizados os critérios linguístico, pedagógico, comunicativo, pragmático e etiógico; Durão (2007), o gramatical.

Quadro 2 - Critério linguístico (VÁZQUEZ, 1999)

\begin{tabular}{|l|l|}
\hline Erro por adição & $\begin{array}{l}\text { Inclusão de um morfema ou de um vocábulo } \\
\text { redundante ou inadequado a um determinado } \\
\text { contexto }\end{array}$ \\
\hline Erro por omissão & $\begin{array}{l}\text { Supressão de um morfema ou vocábulo } \\
\text { indispensável em determinado contexto }\end{array}$ \\
\hline Erro por falsa colocação & $\begin{array}{l}\text { Colocação dos elementos que constituem a } \\
\text { frase em uma ordem sintagmática incorreta ou } \\
\text { pouco frequente }\end{array}$ \\
\hline Erro por justaposição & $\begin{array}{l}\text { União de duas frases ou vocábulos sem } \\
\text { atentar-se para a sintaxe }\end{array}$ \\
\hline
\end{tabular}

Quadro 3 - Critério pedagógico (VÁZQUEZ, 1999)

\begin{tabular}{|c|c|}
\hline Erros induzidos $\mathrm{x}$ criativos & $\begin{array}{l}\text { - Erros induzidos pela forma como } \\
\text { determinado elemento foi apresentado ao } \\
\text { aprendiz, e como ele a praticou } \\
\text { - Erros que apresentam estruturas criadas a } \\
\text { partir dos elementos que o aprendiz tem à } \\
\text { disposição, como sua LM, as regras da L2 }\end{array}$ \\
\hline Erros transitórios $\mathrm{x}$ permanentes & $\begin{array}{l}\text { - Erros típicos dos estados naturais de } \\
\text { desenvolvimento } \\
\text { - Erros que tendem a permanecer na L2 dos } \\
\text { aprendizes }\end{array}$ \\
\hline Erros fossilizáveis $\mathrm{x}$ fossilizados & $\begin{array}{l}\text { - Erros que tendem a permanecer } \\
\text { - Erros que permanecem quando se } \\
\text { acreditavam erradicados }\end{array}$ \\
\hline Erros individuais $\mathrm{x}$ coletivos & $\begin{array}{l}\text { - Objeto de análise é produzido por um único } \\
\text { aprendiz } \\
\text { - Objeto de análise é produzido por um grupo } \\
\text { de aprendizes }\end{array}$ \\
\hline Erros de produção escrita $\mathrm{x}$ oral & $\begin{array}{l}\text { - Objeto de análise é uma produção escrita } \\
\text { - Objeto de análise é uma produção oral }\end{array}$ \\
\hline
\end{tabular}


O critério pedagógico apresenta os tipos de erros de acordo com o nível em que o aprendiz se encontra. São eles:

Erros de aprendizes de nível iniciante

- Violação sistemática de regras

- Uso de estruturas altamente idiossincráticas

- Insegurança referente à correção ou incorreção da estrutura utilizada

- $\quad$ Similaridade com as regras da LM ou L3

- $\quad$ Reduzido número de erros devido à reduzida capacidade linguística

Erros de aprendizes de nível intermediário

- Alternância quanto à aparição de formas corretas e incorretas

- Maior frequência de erros intralinguais que interlinguais

- $\quad$ Erros em que o aluno ignora a convergência entre LM e L2, indicando que ele se move somente no sistema da L2

- $\quad$ Elevado número de erros de todo tipo

Erros de aprendizes de nível avançado

- $\quad$ Erros semelhantes aos dos falantes nativos

- $\quad$ Erros fossilizados

- $\quad$ Estruturas corretas, mas inadequadas ou inaceitáveis

- Capacidade quase automática de autocorreção

- $\quad$ Erros de interlíngua que consideram somente a LM e nunca uma outra língua aprendida

- Ausência de erros criativos, exceto no campo léxico

- $\quad$ Erros residuais de caráter individual

Quadro 4 - Critério comunicativo (VÁZQUEZ, 1999)

\begin{tabular}{|l|l|}
\hline Erros por ambiguidade & Deixam dúvida quanto à mensagem \\
\hline Erros irritantes & $\begin{array}{l}\text { Construções que, embora corretas } \\
\text { morfossintático e foneticamente, não refletem } \\
\text { os hábitos discursivo-culturais da L2, } \\
\text { desgastando o interlocutor }\end{array}$ \\
\hline Erros estigmatizantes & $\begin{array}{l}\text { Construções que apresentam marcas da LM } \\
\text { do aprendiz, as quais o identificam como } \\
\text { pertencente a um grupo estrangeiro } \\
\text { determinado }\end{array}$ \\
\hline
\end{tabular}

Quadro 5 - Critério pragmático (VÁZQUEZ, 1999)

Erros de pertinência ou discursivos

Desvio que se produz referente às regras que regulam os intercâmbios orais ou escritos, no tocante a coerência, coesão, cooperação, turnos, silêncios, pausas 
Quadro 6 - Critério etiológico (VÁZQUEZ, 1999)

\begin{tabular}{|l|l|}
\hline Erros interlinguais & $\begin{array}{l}\text { São produto da interferência da LM, bem } \\
\text { como de outras línguas aprendidas, nas } \\
\text { estruturas da L2 }\end{array}$ \\
\hline Erros intralinguais & $\begin{array}{l}\text { São produto de conflito interno das regras da } \\
\text { L2 }\end{array}$ \\
\hline Erros por simplificação & Os aprendizes simplificam as regras da L2 \\
\hline
\end{tabular}

Quadro 7 - Critério gramatical (DURÃO, 2007)

\begin{tabular}{|l|l|}
\hline Erro fonético-fonológico & $\begin{array}{l}\text { Equívocos causados por oposições } \\
\text { fonológicas ou por existência de sons } \\
\text { diferentes na LM dos aprendizes }\end{array}$ \\
\hline Erro ortográfico & Afeta a forma gráfica das palavras \\
\hline Erro morfológico & Refere-se à forma das palavras \\
\hline Erro sintático & Refere-se à construção dos enunciados \\
\hline Erro léxico-semântico & Afeta o significado dos vocábulos \\
\hline Erro discursivo & $\begin{array}{l}\text { Afeta a constituição discursiva dos } \\
\text { enunciados. }\end{array}$ \\
\hline
\end{tabular}

Os critérios apresentados devem ser vistos como um todo construído por diversos autores desde a década de 1970, mas que têm como marco o artigo de Corder, de 1967, sobre os erros dos aprendizes de L2. Outro aspecto relevante sobre os critérios é que, observando-os, chega-se à compreensão de que em sua maioria são tradicionais, pois, como revela Camargo (2009, p.23), “fundamentam-se quase que exclusivamente na correção gramatical [...]". Somente nos últimos anos do século XX é que outras teorias somaram-se à $\mathrm{AE}$, como, por exemplo, a da competência comunicativa, formulada a partir da Etnografia da Comunicação." Outro exemplo de teoria não centrada no aspecto gramatical é a da Interlíngua (SELINKER, 1972), a qual, somando-se à AE, dotou-a de mais instrumentos para tratar das hipóteses dos aprendizes. O conceito principal desta teoria é o de fossilização, já referido neste trabalho quando da descrição do critério pedagógico. Tal conceito trata dos erros relativos à transferência da LM que permanecem nas produções dos aprendizes de L2 quando, pelo tempo de estudo, já se acreditavam erradicados. É importante ferramenta para se verificar, por exemplo, se um determinado erro faz parte do estágio de aprendizado do aluno, sendo, portanto, transitório; ou se exige uma intervenção do professor, por já estar nas produções desse aluno por um período além do estágio em que tal erro é comum. A fossilização é um dos conceitos do modelo de Interlíngua, teoria que se apresenta a seguir e que compõe o 
quadro teórico para a análise linguística das produções dos alunos bolivianos aprendizes de língua portuguesa como L2.

\subsection{Interlíngua}

As produções dos alunos bolivianos apresentam um componente que as produções dos alunos brasileiros não possuem: a possibilidade de transferência da LM espanhola ${ }^{7}$. Assim, associam-se à $\mathrm{AE}$, somente para as produções dos alunos bolivianos, os conceitos desenvolvidos por Selinker (1972) sobre Interlíngua.

Durante a aquisição de uma determinada L2, o aprendiz pode se comunicar utilizando um sistema linguístico que apresenta elementos da sua LM, como, por exemplo, estrutura, fonologia, sufixos; conjugados a elementos que aprendeu da L2, resultando em um sistema linguístico misto e intermediário. A esse sistema, Selinker denominou Interlíngua (doravante IL). Para o autor, que assim como Corder se serviu dos conceitos de aquisição linguística e GU de Chomsky, as construções dos aprendizes de L2 realizam-se sob um código intermediário construído a partir de estruturas linguísticas latentes utilizadas e desenvolvidas durante o processo de aquisição da LM. O autor verificou que essas construções são sistemáticas e variáveis. Sistemáticas na medida em que utilizam o input recebido para preencher a GU, ou seja, o mecanismo de aquisição linguística; e variáveis, porque a cada estágio do aprendizado o aprendiz de L2 vai se aproximando das estruturas da língua alvo, e isso vai variando de acordo com o avançar de seus estudos.

Voltando por um momento à $\mathrm{AE}$, é importante chamar atenção para o fato de Corder ter tratado, em seu artigo de 1967, da interferência que o aprendiz de L2 sofre dos hábitos desenvolvidos na aquisição da LM, sendo uma evidência disso o grande número, embora não a totalidade, de seus erros estar relacionado com os sistemas de sua primeira língua. Selinker avança na compreensão dessa interferência quando sugere os processos psicológicos que afetam as produções linguísticas dos aprendizes de L2. São eles:

\footnotetext{
${ }^{7}$ Não foi constatada transferência de outra língua materna que não fosse a espanhola. Inicialmente, considerou-se a transferência da língua aimará, idioma falado na porção oeste do departamento de La Paz, de onde se origina a maior parte dos imigrantes bolivianos imigrantes no Brasil. No entanto, após a realização de descrição desta língua, com o apoio da obra do linguista boliviano Grondin (1999), foi possível observar que não há vestígios do aimará nas produções em língua portuguesa dos alunos bolivianos. A descrição encontra-se no APÊNDICE 1.
} 
Quadro 8 - Processos psicológicos (SELINKER, 1972)

\begin{tabular}{|l|l|}
\hline Transferência intrusiva & $\begin{array}{l}\text { Uso consciente de estruturas da L1 na L2 } \\
\text { como forma de suprir elementos que o } \\
\text { aprendiz desconhece }\end{array}$ \\
\hline Transferência criativa & $\begin{array}{l}\text { Criação de léxico com estruturas ou partes } \\
\text { fixas da L1 na L2 }\end{array}$ \\
\hline Hipergeneralização de regras & $\begin{array}{l}\text { Aplicação de uma regra da L2 para áreas } \\
\text { não regida por ela devido a a } \\
\text { desconhecimento de outras regras }\end{array}$ \\
\hline Evasão & $\begin{array}{l}\text { Não uso ou não aprendizado de estruturas } \\
\text { por parecerem difíceis }\end{array}$ \\
\hline Hipercorreção & $\begin{array}{l}\text { Aplicação de uma regra da L2 para áreas } \\
\text { que aparentemente }\end{array}$ \\
\hline Aprendizagem de holofrases & $\begin{array}{l}\text { Recurso de comunicação em que uma } \\
\text { palavra é empregada em substituição a uma } \\
\text { frase }\end{array}$ \\
\hline Pronúncia cognata & $\begin{array}{l}\text { Pronúncia de vocábulos da L2 influenciada } \\
\text { por vocábulos semelhantes, também da L2, } \\
\text { mas compostos por fonemas que o } \\
\text { aprendiz, na fala, não demonstra distinguir }\end{array}$ \\
\hline Pronúncia ortográfica & $\begin{array}{l}\text { Pronúncia de acordo com a ortografia, não } \\
\text { de acordo com a fonologia da L2 }\end{array}$ \\
\hline Fossilização & $\begin{array}{l}\text { Elementos da IL que permanecem na L2 } \\
\text { independente dos novos aprendizados, sem } \\
\text { apresentar progressão }\end{array}$ \\
\hline
\end{tabular}

A respeito dos processos psicolinguísticos descritos, Selinker (1972) afirma que o mais recorrente é o da fossilização, a qual ocorre por fatores extrínsecos e intrínsecos. Os extrínsecos são pressão ou urgência comunicativa, tipo de input que o aprendiz recebe, falta de oportunidade de praticar a L2, demonstração dos falantes nativos de que entendem os enunciados produzidos pelo aprendiz e a metodologia empregada no ensino da L2; os intrínsecos são relacionados a sexo, idade, motivação e atitude.

Como visto, os modelos de AE e IL se complementam na função de fazer destacar as hipóteses formuladas pelo aprendiz para a aquisição de L2. Porém, há ainda um terceiro modelo dentro da Linguística Contrastiva, o da Análise Contrastiva (doravante AC), o qual apresenta e confronta o sistema das línguas em contato consideradas na aquisição de uma L2. A seguir o modelo de AC.

\subsection{Análise Contrastiva}

Compõe o quadro teórico que fundamenta as reflexões linguísticas da presente pesquisa, além da AE e da IL, o modelo de Análise Contrastiva. Este modelo teve seu 
apogeu no início da década de 1960, durante o já citado Condutivismo, quando se fazia o contraste entre aspectos da LM do aprendiz e da L2 em estudo, visando a identificar os pontos de convergência e de divergência entre as línguas. Os de convergência seriam os pontos que resultariam em facilidades para o aprendiz; o de divergência revelariam as dificuldades. Por meio da antecipação das dificuldades, de acordo com a AC, seria possível antever e evitar os erros do aprendiz, sendo os erros as transferências de estruturas da LM para as produções em L2.

Contudo, quando o erro passou a não representar aquilo que deveria ser evitado, mas aquilo que poderia indicar o engenho do aprendiz na aquisição linguística, houve a revisão da importância da AC. Esse momento de revisão da apreciação do erro, como o descrito no início deste capítulo, gerou os modelos de AE e IL vistos. Mas a AC não foi de todo dispensada, pois o contraste entre aspectos das línguas envolvidas no processo de aquisição linguística de um aprendiz ainda serve como um dispositivo de filtro inicial que abre caminho para testar hipóteses sobre as hipóteses dos aprendizes. Desse modo, para a presente pesquisa, optou-se por adotar o conceito de transferência da $\mathrm{AC}$, o qual se subdivide em positiva ou negativa:

Quadro 9 - Transferências

\begin{tabular}{|l|l|}
\hline Transferência positiva & $\begin{array}{l}\text { Transferência de hábitos ou de elementos da } \\
\text { LM do aprendiz coincidentes com hábitos ou } \\
\text { elementos da L2. São considerados produtivos } \\
\text { para o desempenho do aprendiz }\end{array}$ \\
\hline Transferência negativa & $\begin{array}{l}\text { Transferência de hábitos ou de elementos da } \\
\text { LM do aprendiz não coincidentes com os } \\
\text { hábitos ou elementos da L2. Constituem-se } \\
\text { como inibidores da aprendizagem da L2 pelo } \\
\text { aprendiz }\end{array}$ \\
\hline
\end{tabular}

Conclui-se, assim, a apresentação do quadro teórico para as análises e reflexões linguísticas, o qual é composto pelos modelos de $\mathrm{AE}$, para as produções dos alunos brasileiros e dos bolivianos; IL, exclusivamente para as produções dos alunos bolivianos; e AC, para a apreciação do tipo de transferência que as produções dos alunos bolivianos podem conter.

Na sequência, os conceitos que nortearam as análises e reflexões culturais das produções textuais dos alunos brasileiros e bolivianos. 


\subsection{Cultura e Ethos Discursivo}

A análise cultural das produções dos alunos brasileiros e dos bolivianos tem o objetivo de apontar os valores, crenças e visão de mundo - os identificáveis - desses aprendizes, o que pode converter-se em auxílio para professores, tanto para a interpretação das diferenças entre seus alunos, quanto para a elaboração das ações de que lançará mão para promover a integração numa sala de aula mista. Segundo Brown (1994 apud CAMARGO, 2009, p.47) ${ }^{8}$, "não se pode dissociar língua e cultura", pois é ela, a cultura, que regula o significado e a interpretação dos enunciados dos discursos em uma dada língua.

A perspectiva a partir da qual se analisam os textos considera a cultura como:

[...] um sistema de crenças e valores e uma organização sociopolítica que configuram um modo de agir e interagir, de fazer, de dizer e de comportar-se de uma dada sociedade. A palavra cultura possui uma diversidade de significados já que engloba tanto o saber cotidiano (experiência comum), bem como o saber intelectual (a experiência refletida). Esse saber comum corresponde à ideia de espírito do povo [...] (TROUCHE, 2005, p. 69)

Aprofundando-se sobre a ideia de espírito do povo, a autora sintetiza o aspecto relativo à cultura que a presente pesquisa visa a ressaltar:

O discurso de cultura nacional se caracteriza por construir identidades desde o passado (mesmo mítico) até o futuro, em processo contínuo. A narrativa de uma cultura nacional pode ser desenvolvida de várias maneiras: nas histórias e nas literaturas nacionais; na ênfase nas origens, na continuidade, na tradição e na intemporalidade; na invenção de uma tradição; no mito fundacional; na ideia de um povo original. A ideia de uma cultura nacional congrega inúmeros significados no sistema de representação de uma dada identificação. [...] A busca, portanto, da compreensão das formas de produção de sentido em dada sociedade, baseada na concepção da natureza interdiscursiva da palavra, e, por extensão, da linguagem, nos impele a entender a constituição da significação como um processo cultural que se dá entre os indivíduos, isto é, no compartilhar de uma ideologia. (TROUCHE, 2005, p. 70)

\footnotetext{
${ }^{8}$ BROWN, H.D. Principles of Language Learning and Teaching. New Jersey, USA.Prentice Hall Regent,1994
} 
Verifica-se, portanto, que a constituição da significação, bem como o seu compartilhamento entre indivíduos por meio da linguagem, são permeados pela cultura, tratada como um saber comum. Quando Brown (1994 apud CAMARGO 2009) trata da indissociabilidade entre língua e cultura, a afirmação é base para defender o ensino cultural para aprendizes de uma determinada L2, objetivando que esses aprendizes se apoderem dos saberes comuns que os falantes nativos dessa determinada língua adquiriram no contínuo das formulações e recepções dos discursos de sua LM. No entanto, a presente pesquisa analisa as produções de turmas mistas, as quais congregam, em constante interação, alunos brasileiros e bolivianos. Assim, a consideração dos aspectos culturais não deve estar restrita àqueles dominados pelos falantes nativos da língua alvo, pois, dessa forma, haveria saberes comuns negligenciados - os dos alunos bolivianos -, os quais estão presentes nas interações entre os indivíduos dessas turmas mistas.

De acordo com Jung (1997, p. 24), entende-se interação como "padrões de alocação de direitos e obrigações interacionais entre todos os membros que estão em conjunto, desenvolvendo uma situação social". Portanto, se o ambiente em questão congrega brasileiros lusofalantes e bolivianos bilíngues (espanhol e português em estágio de aquisição), aprendizes de língua portuguesa como LM e L2, respectivamente, e em interação constante, é indispensável a consideração intercultural, a qual permite a emersão e a interpretação dos saberes comuns dos envolvidos no conjunto.

Os elementos desses saberes comuns são identificados e estudados na presente pesquisa com o auxílio da Análise do Discurso, campo da Linguística e da Comunicação que possibilita apontar as construções ideológicas presentes nos textos, e, a partir delas, a visão de mundo, os valores éticos e morais do autor. A Análise do Discurso (doravante $\mathrm{AD}$ ) concebe o discurso como uma prática de construção de significados que vincula o autor ao seu contexto sócio-histórico, o qual é compreendido como resultado da experiência social, portanto, não individual. Assim, os discursos carregam informações sobre saberes comuns que relacionam seus autores ao seu grupo e a sua época, aspectos referentes aos alunos brasileiros e aos bolivianos que a presente pesquisa visa a identificar e analisar por meio da verificação da maneira como o autor de um discurso constrói a sua imagem.

A forma como o autor de um discurso se mostra, se apresenta e se posiciona pode dar informações sobre seus valores e visão de mundo, os quais podem ser ou não ser compartilhados com o grupo, mas, certamente, serão resultado de sua experiência 
social. O conceito de ethos, com o qual se aponta, segundo Amossy (2005, p. 11), “a inscrição do locutor e a construção da subjetividade na língua", é instrumento que auxilia a verificação dos valores e visão de mundo dos autores dos discursos. A ideia de ethos está presente nas ciências humanas ocidentais desde Aristóteles, quando, nos estudos de retórica, tratava da forma como o orador se apresentava para a sua plateia. A AD se apropria deste conceito e o utiliza como identificador da maneira como o autor de um discurso constrói a imagem de si. Para a autora,

Todo ato de tomar a palavra implica a construção de uma imagem de si. Para tanto, não é necessário que o locutor faça seu autorretrato, detalhe suas qualidades, nem mesmo que fale explicitamente de si. Seu estilo, suas competências linguísticas e enciclopédicas, suas crenças implícitas são suficientes para construir uma representação da sua pessoa. Assim, deliberadamente ou não, o locutor efetua em seu discurso uma representação de si. (AMOSSY, 2005, p. 9)

Essa representação de si está relacionada às características, reais ou não, de que o enunciador se imbui para a persuasão do seu interlocutor. Para Maingueneau (2005), o ethos está ligado à enunciação e não a um saber extradiscursivo sobre o enunciador. No entanto, o mesmo autor afirma que "o poder de persuasão de um discurso decorre em boa medida do fato de que leva o leitor a identificar-se com a movimentação de um corpo investido de valores historicamente especificados" (MAINGUENEAU 2005). Desse modo, mesmo quando as características só pertencem à enunciação e não são de fato pertencentes ao caráter do enunciador do discurso, elas apontam para aquilo em que ele se apoia como valorizado ou desvalorizado dentre os estereótipos sociais de seu tempo.

Para entendermos o ethos, é necessário compreendê-lo como parte dos elementos constitutivos do discurso. Segundo Eggs (2005), autor que retoma a concepção aristotélica de organização da retórica, o discurso é formado por três elementos: logos, ethos e pathos, assim definidos:

Quadro 10 - Elementos do discurso (EGGS, 2005)

\begin{tabular}{|l|l|l|}
\hline \multicolumn{1}{|c|}{ logos } & \multicolumn{1}{|c|}{ ethos } & \multicolumn{1}{c|}{ pathos } \\
\hline Raciocínio & Virtude & Paixão \\
Argumentação & Caráter & Afeto \\
\hline
\end{tabular}


Assim, o discurso íntegro, para convencer interlocutores, seria constituído, segundo o autor, por raciocínio, "aquele que convence em si e por si mesmo" (o logos); imagem do enunciador (o ethos) a qual, conferindo-lhe caráter, irá auxiliá-lo no convencimento; e o afeto demonstrado para com o interlocutor (o pathos), mediante o qual se obterá a aceitação da argumentação pelo fato de o enunciador levar em consideração a sua plateia.

Dos três elementos constituintes do discurso, o ethos se mostra critério de análise compatível com as necessidades da pesquisa, na medida em que evidencia, por meio da construção da imagem que o enunciador faz de si, seus valores e caráter diante de uma problemática específica, com indivíduos concretos.

Portanto, o ethos é um modulador, um regulador da forma como o enunciador apresenta seu raciocínio (logos) e demonstra afeto (pathos) pelo interlocutor, procurando atingir a justa medida, sem cair nos extremos do excesso ou da falta. Eggs (2005), quando retoma Aristóteles, oferece, como exemplos de justa medida para a sociedade grega, a coragem e a generosidade, defendendo que são virtudes relacionadas às "paixões humanas", paixões que jamais denotam um comportamento fixo, mas que, arrazoadas por um homem sábio, são apresentadas em posição intermediária:

Quadro 11 - A justa medida (EGGS, 2005)

\begin{tabular}{|l|l|l|}
\hline \multicolumn{1}{|c|}{ falta } & \multicolumn{1}{|c|}{ justa medida } & \multicolumn{1}{c|}{ excesso } \\
\hline $\begin{array}{l}\text { covardia } \\
\text { avareza }\end{array}$ & $\begin{array}{l}\text { coragem } \\
\text { generosidade }\end{array}$ & $\begin{array}{l}\text { temeridade } \\
\text { prodigalidade }\end{array}$ \\
\hline
\end{tabular}

Para a sociedade grega, coragem e generosidade constituíam valores considerados virtudes, situados fora dos extremos da falta ou do excesso. Tais valores, portanto, eram os disponíveis nesta sociedade como parte dos saberes comuns, os quais, indexados em representações compartilhadas, figuravam nos discursos produzidos, e orientavam as escolhas do enunciador sobre o que seria adequado ou não, valorizado ou não. Ao final, não revelariam o posicionamento de apenas um elemento daquela sociedade, mas o posicionamento adotado ou reconhecido culturalmente entre os membros, formando o que Kerbrat-Orecchioni chama ethos coletivo: 
É muito razoável supor que os diferentes comportamentos de uma mesma comunidade obedecem a uma certa coerência profunda e, então, esperar que sua descrição sistemática permita distinguir o "perfil comunicativo", ou ethos, dessa comunidade (ou seja, a sua maneira de se comportar e de se apresentar nas interações - mais ou menos caloroso ou frio, próximo ou distante, modesto ou imodesto, "sem constrangimentos" ou respeitoso do território alheio, suscetível ou indiferente à ofensa etc.) (KERBRAT-ORECCHIONI, $1996^{9}$ apud MAINGUENEAU, 2008, p. 16-17)

Assim, a identificação do ethos coletivo depreensível do discurso dos alunos brasileiros e dos bolivianos resultará na apreciação daquilo que é compartilhado como saber comum, valorizado ou não, pelos integrantes das duas culturas consideradas.

${ }^{9}$ KERBRAT-ORECCHIONI, Catherine. La conversation. Paris: Seuil, 1996. 


\section{CAPÍtULO 2. CONTEXTO E METODOLOGIA DA PESQUISA}

O presente capítulo destina-se a fornecer informações sobre a escola escolhida como campo para a obtenção do corpus, e a expor a metodologia empregada nas análises realizadas. Compõem o capítulo:

2.1 Apresentação da escola;

2.2 Questionário aplicado aos professores sobre a experiência em lecionar em salas de aula mistas, de cujas respostas foi formulada a pergunta da pesquisa;

2.3 Atividade escrita aplicada às turmas de $8^{\circ}$ ano, o que constituiu o corpus analisado;

2.4 Metodologia empregada para a análise dos aspectos linguísticos do corpus; e

2.5 Metodologia empregada para a análise dos aspectos culturais do corpus.

\subsection{Apresentação da escola}

A Escola Municipal de Ensino Fundamental Infante D. Henrique localiza-se no bairro do Canindé, no Pari, entre o centro e a zona leste da cidade de São Paulo. É um bairro plano, assim como é a várzea do rio Tietê onde se desenvolveu. É bastante caracterizado pelas construções baixas, havendo grande número de sobrados da segunda metade do século $\mathrm{XX}$, os quais servem como residências e pequenos negócios para a manutenção do cotidiano. Tendo o Brás ao lado, bairro fundamentalmente ligado ao comércio têxtil e que absorve a mão de obra imigrante boliviana, o Canindé, por ser acessível às classes média e baixa, é o bairro moradia, dormitório para grande parte desses estrangeiros. Assim, a população da escola, refletindo a população do bairro, é composta por filhos de brasileiros e de imigrantes trabalhadores e moradores da região, sendo os bolivianos os estrangeiros em maior número. Dos 600 alunos que compõem o quadro da escola, 30 são bolivianos e 50 são descendentes de bolivianos ${ }^{10}$, o que faz desta instituição campo propício para a presente pesquisa.

Localizada em frente a uma praça numa rua de pouco movimento, esta escola tem seu portão principal aberto durante o horário de funcionamento, o que torna a aproximação amistosa. A segurança dos alunos se dá pelo acesso interno impedido na

\footnotetext{
${ }^{10}$ Dados do Levantamento de Alunos Estrangeiros Infante 2012, documento fornecido pela coordenação da EMEF Infante D. Henrique.
} 
secretaria, a qual opera a comunicação com os visitantes por uma grande janela de vidro, colocada ali para substituir as antigas grades internas, "porque aqui ninguém é animal, né?”, explicou o diretor, atualmente, no seu terceiro ano na instituição.

Internamente, a construção de pavimento único térreo constitui-se de um longo corredor margeado de salas de aula em cujo fim situa-se uma biblioteca/sala de leitura, a qual é bastante utilizada pelos alunos - devido ao claro empenho da escola, e da professora responsável pelo espaço, em manter projetos como a AEL (Academia Estudantil de Letras) de cuja cerimônia de posse de novos escritores-leitores-estudantes participei, podendo atestar, inclusive, a larga adesão tanto de membros brasileiros quanto de estrangeiros, notadamente os bolivianos.

A escola, de ensino fundamental I e II, conta com um diretor, uma vice-diretora, duas coordenadoras, seis funcionários e 28 professores, a maioria mulheres, com quem travei os primeiros contatos, buscando saber sobre a experiência em ensinar em salas de aula mistas. Além de conversas informais, obtive tais informações por meio da aplicação de um questionário, de cujas respostas foi elaborada a pergunta da pesquisa.

\subsection{Questionário aplicado aos professores}

O objetivo de aplicar um questionário aos professores foi o de formalizar e complementar as conversas informais, ligeiras, entrecortadas dos primeiros contatos, por meio das quais se expunham o dia-a-dia na escola, o trabalho com os alunos em geral, e as particularidades dos bolivianos. Foram essas conversas que basearam a elaboração do questionário, a partir do qual foi possível saber mais sobre a visão dos docentes a respeito das especificidades do trabalho com alunos bolivianos.

\section{Questionário sobre recepção/integração de alunos bolivianos imigrantes nas escolas públicas de São Paulo}

1. Cargo que ocupa na escola

2. Disciplina(s) que ministra

3. Séries com que trabalha

4. Quantos alunos bolivianos você tem por turma?

5. Seus alunos bolivianos apresentam alguma dificuldade de interação com os alunos brasileiros? Se sim, qual ou quais?

6. Seus alunos bolivianos apresentam alguma dificuldade na sua disciplina, quer seja pela língua ou pelo conteúdo específico da matéria? Se sim, qual ou quais? 
7. Como foi a sua experiência inicial com os alunos bolivianos? Como foi a sua adaptação, como professora, a uma turma mista? Quais foram as suas estratégias, dificuldades, o que deu certo, o que não deu?

8. Na sua opinião, seria importante haver um programa de recepção para alunos bolivianos que vão ingressar nas escolas públicas de São Paulo? Se sim, como deveria ser?

Dos 28 professores da escola, 9 professoras se dispuseram a responder o questionário, sendo 6 do ensino fundamental II e 3 do fundamental I. A seguir, quadro com as respostas mais frequentes:

Quadro 12 - Respostas mais frequentes das professoras ao questionário aplicado

Respostas mais frequentes (foram conservadas as expressões usadas pelas professoras)

Alunos bolivianos ficam juntos e fazem atividades juntos (4 professoras)

Alunos brasileiros têm preconceito, não querem sentar junto com os bolivianos (2 professoras)

(os alunos bolivianos) São bem aceitos de um modo geral (1 professora)

(os alunos bolivianos) São dedicados, possuem rotina de estudos em casa (4 professoras)

(os alunos bolivianos) Apresentam insegurança, timidez e pouca interação (3 professoras)

Os que não falam português têm muita dificuldade de interação e na escrita (4 professoras)

Os bolivianos que falam português ajudam os que não falam (2 professoras)

Eu conheço o idioma espanhol, então não tive problemas (2 professoras)

Minha estratégia foi fazer trabalhos em grupo e rodízio de grupos (2 professoras)

Um projeto de recepção dos alunos bolivianos deve envolver também os pais, os outros alunos, os professores, a direção e a cultura boliviana para esclarecer (4 professoras)

As respostas forneceram informações relevantes sobre aceitação dos alunos bolivianos por parte dos brasileiros, integração, relação com as responsabilidades escolares, costumes de estudos, características psicológicas, domínio da língua portuguesa, relação intragrupo, estratégias empregadas pelas professoras e reflexão sobre a necessidade e a abrangência de um programa de recepção para alunos bolivianos em escolas públicas brasileiras.

Sobre o programa de recepção, inicialmente, esse assunto esteve presente porque parecia representar uma possibilidade de avançar na integração dos alunos bolivianos ao contexto escolar brasileiro. Tal programa, no decorrer da pesquisa, foi perdendo espaço para as ações de integração que foram surgindo naturalmente na escola, assunto tratado nesta pesquisa no capítulo 4. Por ora, para tratar das respostas ao questionário, foi importante observar que, na opinião das professoras, qualquer programa de recepção deveria envolver não somente os alunos bolivianos, mas também os outros alunos, a família, a direção, ou seja, não poderia se tratar de algo de cima para baixo - da direção 
escolar para os alunos - mas de algo horizontal, entre os alunos e com a participação de todos os envolvidos.

Esse tipo de complexidade nas respostas refletiu não somente o cotidiano vivido pelas professoras, mas também sua visão sobre os alunos e o que os envolve, notadamente na escolha das palavras e expressões como "sentar junto", "dedicados", "apresentam timidez", "envolver os pais e a cultura”, o que revelou atuação consciente e reflexiva por grande parte delas. Ficou evidente, de acordo com a maioria das professoras, que os alunos bolivianos se organizam de modo a se ajudar, formando grupos; que a interação passa pelo domínio da língua portuguesa; que o conhecimento da língua espanhola é um facilitador para o trabalho do professor; e que a timidez é uma das grandes marcas destes estudantes, a qual, para as professoras, se manifesta no silêncio. Assim, pelos aspectos linguísticos e culturais serem aquilo que representava desafio para as professoras, na medida em que exigia delas esforço para se comunicar com o aluno boliviano, bem como para interpretar seu comportamento, chegou-se à pergunta da pesquisa:

Quais são as características linguísticas e culturais que diferenciam ou aproximam alunos bolivianos e brasileiros em uma sala de aula mista?

Responder ou gerar reflexão sobre essa pergunta é o objetivo da presente pesquisa, a partir do que se pretende que o professor possa identificar padrões em salas de aula que congregam alunos brasileiros e bolivianos, podendo atuar de acordo com as especificidades dos seus alunos. Não se trata de apontar padrões prescritivos ou definitivos, mas de identificar, a partir da experiência que aqui se apresenta, aspectos que podem estar presentes em outras salas de aula cujas características se assemelhem.

Por fim, o questionário aplicado, apesar de ser um canal de comunicação que não privilegia o relaxamento do emissor - justamente por gerar documento escrito proporcionou obtenção de informações seguras, além de maior conhecimento, por parte das professoras, sobre os objetivos da pesquisa.

\subsection{O corpus e a atividade aplicada para a sua obtenção}

O corpus compõe-se de 46 textos escritos, sendo 38 por alunos brasileiros e 8 por alunos bolivianos. A diferença entre as quantidades reflete a proporção de brasileiros e bolivianos nas salas de aula. No entanto, não são alunos de uma só classe. Como já mencionado anteriormente, foram três turmas de $8^{\circ}$ ano a participar da pesquisa, a saber, 
as turmas A, B e C. O objetivo foi o de conseguir o maior número de textos possível, além de obter informações relativas a mais de uma sala de aula, o que não privilegiou aspectos isolados ou características de nenhuma delas em especial. São, portanto, 46 textos, de curta extensão em geral, não chegando a ocupar uma página inteira cada $\mathrm{um}^{11}$.

Para a obtenção do corpus, foi aplicada atividade escrita sobre tema envolvendo violência e amizade. Tais temas foram escolhidos por estarem presentes no cotidiano adolescente, e terem, notadamente em ambiente escolar, função relacionada à constituição das identidades. As amizades constroem-se por meio de identificação, busca de apoio, interesses, revelando as formas como o jovem se relaciona e atua em ambiente social. Em contexto escolar, os alunos encontram-se fora da intervenção ou proteção familiar no que se refere às interações cotidianas. Assim, os jovens atuam seguindo as próprias intuições e estratégias, as quais constroem, fixam e revelam os seus padrões de comportamento. O mesmo ocorre com relação à violência, pois, por meio de atitudes ou posicionamentos envolvendo-a, os adolescentes demonstram capacidade de se comunicar e estabelecer limites, aceitação ou rejeição às atitudes do outro, ou seja, mostram como resolvem os conflitos que se apresentam. Desse modo, analisar, nas produções textuais, as manifestações dos aspectos relacionados à amizade e à violência resulta em identificação de características, visão de mundo e valores sociais e morais referentes aos tipos de interação mais recorrentes no cotidiano desses jovens. A seguir, o texto da atividade motivadora:

\section{Atividade motivadora dos textos}

A foto abaixo é da estampa de uma camiseta. Escreva o que você acha sobre o que está escrito. Diga também se você já teve uma experiência assim na sua vida ou se já viu algum amigo agindo desse jeito. Se sim, conte como foi.

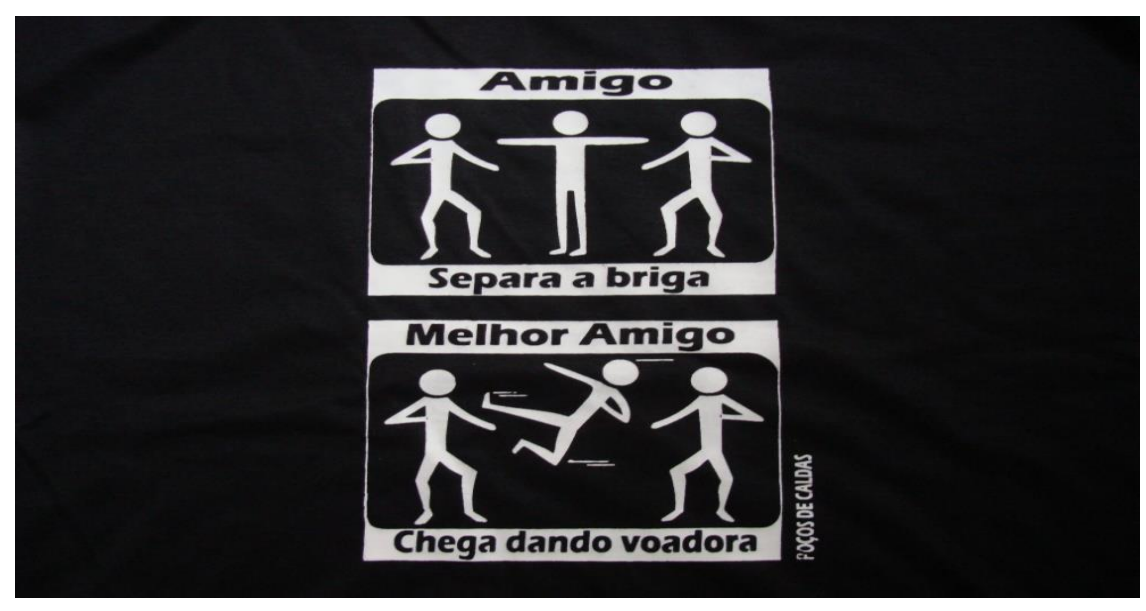

\footnotetext{
${ }^{11}$ Os 46 textos encontram-se transcritos no ANEXO 2 .
} 
Do ponto de vista linguístico, a atividade exige do aluno que possa, a respeito do tema proposto, opinar e narrar, utilizando, para tanto, estruturas e vocabulário básicos, previstos para o seu estágio de formação, tais como: vocabulário cotidiano, tempos do indicativo, conjunções coordenativas, advérbios de lugar e tempo, estrutura narrativa, entre outros elementos disponíveis no repertório formado durante o ensino fundamental. O objetivo foi o de fazer com que o aluno se sentisse à vontade sobre o acesso às estruturas necessárias para tratar de tema cotidiano, o que o afastaria da sensação de avaliação linguística, permitindo que o seu real nível de domínio da língua transparecesse - incluindo o fonético-fonológico, objeto de análise desta pesquisa.

A atividade aplicada, para os objetivos que deveria cumprir, foi bem sucedida, pois possibilitou obtenção de enunciações carregadas de conteúdos culturais significativos, alcançadas devido ao fato de o tema ter relação com o cotidiano dos alunos. Do ponto de vista linguístico, também houve bom aproveitamento da atividade, já que o tema e a proposta exigiam do aluno vocabulário e estruturas básicos, o que gerou despreocupação em demonstrar ou construir um determinado domínio linguístico, mas expondo aquele mais próximo ao real.

\subsection{Metodologia empregada para a análise dos aspectos linguísticos do corpus}

A análise linguística tratou dos aspectos fonético-fonológicos referentes a VOGAL, CONSOANTE, SÍLABA e ACENTO presentes nos textos dos alunos brasileiros e bolivianos. Tais aspectos foram examinados por espelharem a oralidade dos autores dos textos, evidenciando aquilo que, nas produções escritas, marcaria a fala de um estudante brasileiro e o que marcaria a de um estudante boliviano. O objetivo foi o de levar ao professor elementos para orientar um dos primeiros níveis de trabalho linguístico a se realizar em turma mista: o relativo à forma da língua, a qual afeta tanto o registro oral quanto o escrito.

Para tanto, procedeu-se à seleção de trechos das produções que continham inadequações, organizando-os em quatro seções:

1. Produção dos alunos brasileiros

2. Produção dos alunos bolivianos - há 10 anos na escola brasileira, alfabetizados em português 
3. Produção dos alunos bolivianos - há 6 anos na escola brasileira, alfabetizados em espanhol na escola boliviana

4. Produção dos alunos bolivianos - há 1 ano e meio na escola brasileira, alfabetizados em espanhol na escola boliviana

Agrupados dessa maneira, os trechos selecionados deram informações sobre o nível linguístico desses quatro grupos. Assim, foi possível observar o nível dos nativos e o nível dos não nativos, esses últimos em gradação referente ao tempo de escolarização em português. Isso revelou tanto um dos modelos de oralidade nativa ao qual os estudantes bolivianos estão expostos (a fala dos alunos brasileiros), quanto a presença de elementos da LM espanhola nas produções desses estudantes.

Para cada inadequação, buscou-se uma adequação, dentro do mesmo texto, sobre o fenômeno estudado. Por exemplo:

\begin{tabular}{|c|c|}
\hline INADEQUAÇÕES & ADEQUAÇÕES \\
\hline$\ldots$ mechendo com migo...$(41)$ & ...ia brigar comigo... (41) \\
\hline
\end{tabular}

Assim, ao apresentar o erro e o não erro, foi possível, além de observar o fenômeno incidente, verificar também a sua abrangência, ou seja, se o erro era sistemático ou apenas um lapso, se o fenômeno fonético-fonológico incidia somente no início dos vocábulos e não no fim, entre outros. As análises constituíram uma gramática mínima das produções dos quatro grupos. O termo gramática mínima foi emprestado da gramática mínima de errores, de Vázquez (1999). Nas palavras da autora, trata-se de:

[...] um resumen de los errores transitorios, fosilizables y fosilizados que se han observado en la producción escrita y oral de um grupo homogêneo de Estudiantes. La observación habrá tenido lugar a partir de los llamados niveles intermediários y siempre en el marco de la instrucción formal... No describe fenômenos gramaticales exhaustivamente, como ló haria uma gramática descriptiva, sino que lo hace enfocando los problemas desde la perspectiva de quien aprende, considerando su lengua nativa y el estadio de interlengua. (VÁZQUEZ, 1999, p. 89-90. Destaques nossos)

Ao conceito acima foi acrescentado outro, referente ao não erro, defendido por García (2005) quando a autora tratava do ensino de espanhol como segunda língua:

[...] habría que señalar la necesidad de hacer mayor hincapié en la identificación de estructuras utilizadas correctamente y de estructuras, 
problemáticas o no, ausentes en la interlengua de los estudiantes de ELE según las distintas etapas de aprendizaje. (GARCÍA, 2005, p. 617)

Assim, ao final das análises linguísticas, obteve-se "um resumen de los errores" para cada um dos quatro grupos acima indicados, podendo, por meio também da "identificación de estructuras utilizadas correctamente", observar o que é transitório, fossilizável ou fossilizado.

As análises se ativeram aos aspectos fonético-fonológicos, no entanto, em alguns momentos foi inevitável tratar também dos morfológicos, como, por exemplo, quando o fenômeno observado - referente à indicação de timbre da vogal /e/ nas produções dos alunos bolivianos - resultou na não diferenciação entre e conjunção e é verbo:

\begin{tabular}{|l|c|}
\hline \multicolumn{1}{|c|}{ INADEQUAÇÕES } & \multicolumn{1}{c|}{ ADEQUAÇÕES } \\
\hline $\begin{array}{l}\text { Eu já vivi esa emoção, mais não } \boldsymbol{e} \text { boa... (43) } \\
\text {... não vou ficar para sempre com ele } \boldsymbol{e} \text { ele tem } \\
\text { de a comprende a ser consiente. (43) }\end{array}$ & (sem adequações para o fenômeno) \\
\hline
\end{tabular}

Nesses casos, o aspecto morfológico foi tratado como complementação do fenômeno fonético-fonológico.

Por fim, sobre as adequações, vale ressaltar que foram selecionadas aquelas pertencentes ao texto que apresentou inadequação. Não se analisaram, nesta pesquisa, as adequações de todas as produções do corpus.

\subsection{Metodologia empregada para a análise dos aspectos culturais do corpus}

A análise dos aspectos culturais referiu-se ao que se pôde observar de culturalmente marcado nas produções dos alunos sobre o tema proposto, o qual envolvia amizade e violência. Foram selecionados trechos das produções que indicavam a opinião dos autores sobre aspectos depreensíveis do tema: aceitação ou não da violência no interior das relações, papel do amigo como defensor ou não, posicionamento fixo ou flexível adotado a respeito do tema, entre outros. Seguiu-se ao agrupamento dos trechos que reproduziam as opiniões dos alunos brasileiros e dos bolivianos. Desse modo, foi possível observar a recorrência dos aspectos que marcam diferença de visão de mundo baseada nas opiniões, e que espelharam traços da sociedade de origem dos alunos.

Para analisar os trechos, optou-se, dentro da Análise do Discurso, pela identificação do ethos, o qual, conformando a imagem construída de si pelos 
enunciadores, reflete o que é valorizado ou desvalorizado nas culturas em questão - o que, em conjunto, delineia o ethos coletivo dessas culturas.

Ao observar que o ethos coletivo dos brasileiros e dos bolivianos se diferenciava, buscaram-se informações na literatura histórico-social dessas sociedades, de forma a respaldar as análises realizadas. Assim, fundamentaram os elementos do ethos coletivo brasileiro algumas das clássicas reflexões sobre a formação da sociedade brasileira de Gilberto Freyre e Sérgio Buarque de Holanda nas respectivas obras Casa Grande e Senzala (1986) e Raízes do Brasil (1975). Sobre violência, sobretudo entre jovens, os estudos de Nascimento e Cordeiro (2011) puderam fundamentar o que se observou a respeito da naturalização da violência nas enunciações dos nativos.

Buscaram-se também, na literatura histórico-social produzida na Bolívia e sobre a Bolívia, as informações para embasar os apontamentos feitos a respeito das enunciações dos alunos bolivianos. Foram consultados autores como Manuel Vargas (2012) sobre história da Bolívia, Karen Fuentes (2010) sobre a sociedade andina indígena e suas características, Quiroga, Quiroga e Bustos (2007) sobre a família andina e a emigração nessa área da Bolívia.

Desse modo, a análise do ethos pôde ser aprofundada e relacionada a aspectos já tratados sobre as sociedades em questão. O resultado são informações que auxiliam o professor a compreender o comportamento, os silêncios, os posicionamentos, enfim, os valores humanos que podem estar presentes e em interação na sua sala de aula mista. Não se trata de compartimentar os anunciadores em departamentos comportamentais, mas observar o que pode significar suas opiniões e relacioná-las com suas posturas, bem como com aspectos da sua sociedade de origem. 


\section{CAPÍTULO 3. ANÁLISE LINGUÍSTICA: ASPECTOS FONÉTICO- FONOLÓGICOS}

\subsection{Análise linguística da produção dos alunos brasileiros}

Segue a análise dos aspectos fonético-fonológicos da produção dos alunos brasileiros, dividida em quadros relativos a vogal, consoante, sílaba e acento.

\section{Quadro 13 - ASPECTOS REFERENTES A VOGAIS}

\begin{tabular}{|c|c|}
\hline INADEQUAÇÕES & ADEQUAÇÕES \\
\hline $\begin{array}{l}\text {... fiquei um pouco chatiado... (21) } \\
\text {... sinco muleques vieram ... (7) } \\
\text {... ele chego na vuadora... (28) }\end{array}$ & $\begin{array}{l}\ldots \text { isso faz parte das melhores amizades... (21) } \\
\ldots \text { aproveitei o momento e dei um soco... (7) } \\
\text {... um menino brigando... (28) }\end{array}$ \\
\hline \multicolumn{2}{|c|}{$\begin{array}{l}\text { Troca de e por i e de o por u, na escrita, causadas por alçamento de vogal } \\
\text { pretônica na fala. O alçamento caracteriza-se por elevação do ponto de } \\
\text { articulação, no aparelho vocal, durante a realização de vogais. Ocorre, } \\
\text { geralmente, por interferência do ambiente fonológico circundante à vogal. Em } \\
\text { chatiado, a consoante africada /t } \mathbf{t} / \text {, por ser alveolar, alça a vogal média pré-tônica } \\
\text { /e/. Processo semelhante ocorre com o ambiente fonológico da vogal /o/ em } \\
\text { muleques e vuadora, pois as consoantes /m/ e /v/, ambas labiais, alçam a vogal } \\
\text { média pré-tônica /o/ quando esta é o fonema seguinte. } \\
\text { No entanto, nas adequações, o alçamento vocálico das postônicas, que ocorre na } \\
\text { fala, não influenciou o registro escrito. Isso demonstra sensibilização dos alunos } \\
\text { para a escrita do que ocorre no ambiente final do vocábulo em português: } \\
\text { terminado mais em e ou o, e pouco em i ou u, mesmo quando os alçamentos } \\
\text { ocorridos na oralidade indicam o contrário. }\end{array}$} \\
\hline ... eu brigo porque eles começão. (22) & ... sempre que eu brigo separam... (22) \\
\hline \multicolumn{2}{|c|}{$\begin{array}{l}\text { Troca de am por ão em registro escrito, ocorrida por estas serem alomorfes do } \\
\text { ditongo nasal /ãw/. A inadequação na escrita de começão, a qual deveria ser } \\
\text { começam, pode ter origem morfológica, pois o ditongo nasal faz parte de } \\
\text { desinências verbais, que, na escrita, ora se apresentam como am (-am, presente } \\
\text { do indicativo; -ram, pretérito perfeito e mais que perfeito simples do indicativo; } \\
\text {-vam, pretérito imperfeito do indicativo) e ora como ão (-rão, futuro do presente } \\
\text { do indicativo). A diferença também está na tonicidade: as sílabas contendo ão são } \\
\text { tônicas e as que contêm am são postônicas. Porém, a adequação separam pode } \\
\text { indicar outra causa para a inadequação: o verbo começar possui ç na sílaba final, } \\
\text { assim, o aluno pode ter confundido a grafia da palavra que pretendia escrever } \\
\text { (começam) com os diversos substantivos abstratos terminados em -ção, como } \\
\text { explicação, sensação, apresentação. }\end{array}$} \\
\hline
\end{tabular}


Substituição do pronome me por mim, resultando em alçamento vocálico de /e/ para /i/; bem como em nasalização da vogal alçada. O alçamento ocorre pela natureza átona do pronome me. Já a nasalização está relacionada à altura da vogal /i/, a qual é realizada em ponto articulatório próximo ao da consoante nasal $/ \mathbf{m} /$ quando em posição final de sílaba. Pelo fato de a inadequação resultar em pronome que estabelece relação imprópria com os elementos ao redor, o equívoco adquire também dimensão morfossintática. A grafia correta da sílaba me- na palavra menino evidencia que a inadequação localiza-se na dificuldade de o aluno diferenciar os pronomes me e mim na fala, e não na produção da sílaba me-.

\section{Quadro 14 - ASPECTOS REFERENTES A CONSOANTES}

\begin{tabular}{|c|c|}
\hline INADEQUAÇÕES & ADEQUAÇÕES \\
\hline $\begin{array}{l}\text {... brincadeiras de mal gosto... (10) } \\
\text {... isso é muito } \text { normau... (10) } \\
\text {... se envouverem em brigas... (15) } \\
\text {...já acontecel comigo... (22) }\end{array}$ & $\begin{array}{l}\text { Quando estou com amigos... (10) } \\
\ldots \text { já esta resolvido... (15) } \\
\text {... chegou outro menino... (22) }\end{array}$ \\
\hline \multicolumn{2}{|c|}{$\begin{array}{l}\text { Troca de } \mathbf{l} \text { por } \mathbf{u} \text {, ou de } \mathbf{u} \text { por } \mathbf{l} \text { na representação escrita do fonema /w/ em posição } \\
\text { final de sílaba. Ocorre por interferência de processo da fala: a vocalização da } \\
\text { lateral /l/ em final de sílaba e precedida de vogal (coda). A vocalização gera a } \\
\text { homofonia de u e } \mathbf{l} \text {, resultando em neutralização da diferença das letras e } \\
\text { consequente dificuldade na escolha entre uma e outra. } \\
\text { As adequações estou e chegou indicam que, quando se trata do fenômeno acima } \\
\text { ocorrendo na terminação verbal, não há equívoco, já que se trata de uma forma } \\
\text { que se repete no presente e no pretérito perfeito - o que auxilia a memorização da } \\
\text { grafia. O mesmo não se vê quando se trata do fenômeno no radical dos verbos, } \\
\text { observável nas formas envouverem e resolvido, presentes no mesmo texto 15. O } \\
\text { radical dos verbos não tem alta incidência de repetição a ponto de facilitar a } \\
\text { memorização, por isso, talvez, é que no mesmo texto haja grafias diferentes para } \\
\text { o fonema /w/. }\end{array}$} \\
\hline 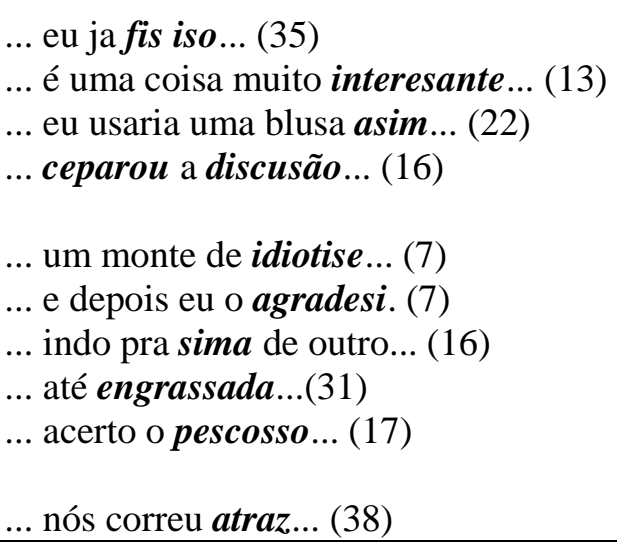 & $\begin{array}{l}\text { (sem adequações para o fenômeno) } \\
\text { (sem adequações para o fenômeno) } \\
\text {... eu acredito nisso... (22) } \\
\text { (sem adequação para o fenômeno) } \\
\text { (sem adequações para o fenômeno) } \\
\text { (sem adequacões para o fenômeno) } \\
\text { (sem adequações para o fenômeno) } \\
\text { (sem adequacões para o fenômeno) } \\
\text { (sem adequações para o fenômeno) } \\
\text {... nós correu atraz... (38) }\end{array}$ \\
\hline
\end{tabular}


Neutralização da representação gráfica do fonema /s/, o qual, em língua portuguesa, pode ser escrito como s, ss, sc, c, ç, sç, $\mathbf{x}, \mathbf{x c}$ e $\mathbf{z}$. As opções são diversas e a escolha implicará, além do conhecimento das regras ortográficas, o domínio de etimologia, ambiente fonológico e morfológico. Nos exemplos, ilustrando as inadequações mais recorrentes, há o uso indevido de $\mathbf{s}$ em ambiente fonológico intervocálico, o qual exigiria ss (iso, interesante, asim, discusão); uso de $\mathbf{s}$ em lugar de $\mathbf{c}$, indicando domínio precário do ambiente morfológico (sufixo -ice em idiotise; formador se verbos de segunda conjugação -ecer em agradesi) e de etimologia (sima: do grego kyma < cima, engrassada: do latim gratia < graça, pescosso: do espanhol pescuezo < pescoço); e a troca de $\mathbf{z}$ por $\mathbf{s}$ e de $\mathbf{s}$ por $\mathbf{z}$, revelando dificuldade de relacionar uma forma verbal conjugada ao seu infinitivo (fis: fazer > fiz), ou uma forma derivada à sua primitiva (atraz: traseira < atrás <trás). Os exemplos converssa e ceparo representam as inadequações mais raras. No primeiro, o uso de ss antecedido por consoante, que não existe como possibilidade gráfica em português, revela inadequação residual do estágio de alfabetização. No último, a forma ceparo , ao contrário da primeira, indica inadequação dentro do que a fonologia da língua portuguesa permite, pois há palavras iniciadas com $\mathbf{c}$ para a grafia de /s/ quando este precede vogal média /e/ (cebola, cerveja), no entanto, indica domínio precário de registro de vocabulário do cotidiano.

As poucas adequações existentes comprovam a dificuldade de os alunos lidarem com a multigrafia do fonema /s/ em português. Assim, a escrita fica dependente da incidência do vocábulo no dia a dia do aluno, e, pela repetição, ocorre a memorização. São exemplos: nisso, nós e Anderson, o nome do melhor amigo. A alternância de grafia de um mesmo vocábulo foi muito rara, como é o caso de ceparo e separa.

... gente que não gosta de brinca. (10)

...começou a me $\boldsymbol{d a}$ voadora... (22)

... chegou e falo deixa eu ve... (22)

... disse que ela vai $v \hat{\boldsymbol{e}} . .$. (5) (sem adequações para o fenômeno)

... o menino com o colar dele... (22)

... não posso disser o nome... (5)

Apagamento da desinência de infinitivo $-\mathbf{r}$, por influência do apagamento, na língua oral, da consoante vibrante $/ \mathbf{r} /$. Ocorre independentemente da quantidade de sílabas do vocábulo ou da altura da vogal precedente, estando relacionado mais fortemente ao fato de a realização da desinência - $\mathbf{r}$ não ser decisiva, na fala, para a identificação de infinitivo. Tal identificação fica a cargo de manter a realização dos vocábulos de forma oxítona, evitando que sejam pronunciados como se fossem verbos no presente do indicativo (ele brinca); no caso dos monossílabos, como dar e ver, o apagamento da desinência $-\mathbf{r}$ pode ocasionar a total ou parcial equivalência à sua forma no presente, como ocorre nos exemplos $\boldsymbol{v} \hat{\boldsymbol{e}}$, em que houve aplicação da regra de acentuação de monossílabos tônicos terminados em e; e $\boldsymbol{d} \boldsymbol{a}$, em que não houve aplicação da regra de acentuação de monossílabos, talvez, pela forma $\boldsymbol{d} \boldsymbol{a}$ confundir-se com a contração da preposição $\boldsymbol{d e}$ com artigo $\boldsymbol{a}$, vocábulo mais presente no repertório escrito dos alunos.

Não houve adequações significativas, indicando que a tendência do fenômeno, quando ocorre, é apresentar-se uniformemente. A grafia correta colar, com o -r final preservado, comprova a incidência do fenômeno na classe dos verbos. E há 


\begin{tabular}{|c|c|}
\hline \multicolumn{2}{|c|}{$\begin{array}{l}\text { o caso de disser, em que há a preservação do }-\mathbf{r} \text { de infinitivo, mas equívoco na } \\
\text { grafia do radical. }\end{array}$} \\
\hline $\begin{array}{l}\text {... é um modo de disse oi... (10) } \\
\ldots \text { não posso disser o nome... (5) }\end{array}$ & $\begin{array}{l}\text { (sem adequações para o fenômeno) } \\
\text { (sem adequações para o fenômeno) }\end{array}$ \\
\hline \multicolumn{2}{|c|}{$\begin{array}{l}\text { Os exemplos apresentam mais de um tipo de inadequação. No primeiro, há o já } \\
\text { analisado apagamento da consoante } \mathbf{r} \text { que representa a desinência -r de infinitivo. } \\
\text { No entanto, o que caracteriza a inadequação que se repete nos dois exemplos é } \\
\text { uma combinação de aspectos fonológico e morfológico. Fonologicamente, há a } \\
\text { representação indevida do fonema /z/ por ss, algo não previsto no sistema } \\
\text { ortográfico do português. Pode ter havido confusão devido à profusão de } \\
\text { grafemas e dígrafos envolvendo as duas consoantes alveolares /s/ e /z/, o que } \\
\text { acarretaria numa hipercorreção. } \\
\text { Morfologicamente, a origem da inadequação está na irregularidade das formas } \\
\text { conjugadas do verbo dizer, que são semelhantes no pretérito perfeito do } \\
\text { indicativo e no futuro do subjuntivo, as quais se confundem com a forma no } \\
\text { infinitivo. Os alunos demonstram ter conhecimento das formas verbais, porém } \\
\text { debilidade na associação do registro escrito à sua realização oral. }\end{array}$} \\
\hline $\begin{array}{l}\ldots . \text { tava brigano... (6) } \\
\ldots \text { e acabei tomano. }(6)\end{array}$ & (sem adequações para o fenômeno) \\
\hline \multicolumn{2}{|c|}{$\begin{array}{l}\text { Apagamento da consoante -d- pertencente à desinência de gerúndio -ndo por } \\
\text { influência do espraiamento (espalhamento) da nasalidade da vogal precedente } \\
\text { para o segmento seguinte, o /d/. A oclusiva oral } / \mathbf{d} / \text {, ao receber o traço de } \\
\text { nasalidade, torna-se nasal, ou seja, o /n/. Essas duas consoantes apresentam } \\
\text { muitos traços comuns - ambas são oclusivas, ambas são alveolares, ambas são } \\
\text { vozeadas. A única diferença é que uma apresenta o traço de nasalidade } / \mathbf{n} / \text { e a } \\
\text { outra não /d/. A escrita do aluno reflete exatamente a oralidade. }\end{array}$} \\
\hline ... amigo não pate, separa. (17) & $\begin{array}{l}\text { Bom eu acho que isso... (17) } \\
\text {... separei a briga mas eles continuaram... (17) }\end{array}$ \\
\hline \multicolumn{2}{|c|}{$\begin{array}{l}\text { Troca de letra b por p. Pode ocorrer por migração do desvozeamento de oclusiva } \\
\text { bilabial /b/ da fala para a escrita. Trata-se de registro próprio da fase de } \\
\text { alfabetização, não muito frequente na série estudada. Daí a única ocorrência. As } \\
\text { adequações bom e briga comprovam a raridade inclusive dentro do texto deste } \\
\text { aluno. }\end{array}$} \\
\hline Ai venho o meu outro amigo e... (4) & (sem adequações para o fenômeno) \\
\hline \multicolumn{2}{|c|}{$\begin{array}{l}\text { Troca de } \mathbf{i} \text { por } \mathbf{n h} \text { no registro escrito de forma conjugada do verbo vir. Ocorre por } \\
\text { fenômenos fonológico e morfológico. Fonologicamente, é decorrente da } \\
\text { nasalização da semivogal, de /j/ para /n /, devido a ambas serem palatais e } \\
\text { sofrerem influência da variação deste ponto de articulação, a depender do falante. }\end{array}$} \\
\hline
\end{tabular}




\begin{tabular}{|l|l|}
\hline $\begin{array}{l}\text { Tal variação migra da fala para a escrita. Morfologicamente, a inadequação é } \\
\text { facilitada por haver a forma verbal venho, do presente do indicativo, tornando-se, } \\
\text { para o aluno, uma alternativa de escrita que se encaixa na variação de realização. }\end{array}$ \\
\hline ... eles que vei pra cima. (22) & ... pra cima de ninguém... (22) \\
\hline \\
Troca de m por i no registro escrito de vogal nasal. Ocorre por ditongação da \\
vogal, de /ẽ// para /ej/, típica da oralidade do português do Brasil. No entanto, \\
além da ditongação, houve desnasalização de /ẽ/. O fenômeno se dá pela \\
variação, de acordo com o falante, do ponto de articulação para a produção do \\
fonema /ẽ/, resultando em uma realização mais ou menos nasal. Essa variação \\
migrou para a escrita. Como no exemplo anterior, há também motivação \\
morfológica. Apesar de vei não ser uma alternativa possível de forma conjugada \\
do verbo vir, a grafia faz parte da forma do pretérito perfeito veio, o que pode ter \\
contribuído para o equívoco. Ao grafar corretamente o vocábulo ninguém, o \\
aluno demonstra que conhece a escrita da nasalização /ẽ/ - que pode ser mais \\
fácil, talvez, de ser memorizada pela regularidade dos pronomes indefinidos \\
ninguém e alguém, ao contrário da irregularidade das formas do verbo vir.
\end{tabular}

\section{Quadro 15 - ASPECTOS REFERENTES A SÍLABAS}

\begin{tabular}{|l|l|}
\hline \multicolumn{1}{|c|}{ INADEQUAÇÕES } & \multicolumn{1}{c|}{ ADEQUAÇÕES } \\
\hline \multicolumn{1}{|c|}{$\begin{array}{l}\text {.. mais isto é um modo da pessoa ... (10) } \\
\ldots \text { mais é muito violento. (13) } \\
\ldots \text { amigo fais tudo com você... (28) } \\
\ldots \text { uma veiz ele me ajudou... (7) }\end{array}$} & $\begin{array}{l}\text { (sem adequações para o fenômeno) } \\
\text { (sem adequações para o fenômeno) } \\
\text { (sem adequações para o fenômeno) } \\
\text {... mas um deles me deu uma rasteira... (7) } \\
\ldots \text { nós saimos correndo... (7) }\end{array}$ \\
\hline
\end{tabular}

Acréscimo indevido de semivogal $\mathbf{i}$ ao vocábulo, causado por ditongação de vogal a ou e ocorrida na fala. A ditongação, no caso dos exemplos, é facilitada pelo ambiente fonológico circundante às vogais. A sibilante /s/, que é realizada em local alto (alveolar) do aparelho fonador, alça o final da vogal precedente, criando um prolongamento semivocalizado em $/ \mathbf{j} /$. O fenômeno fonológico, que influenciou o registro ortográfico da conjunção mas, foi reforçado pela existência do advérbio mais, já que, devido à ditongação, os dois tornam-se homófonos. Daí a confusão do aluno para eleger a forma da escrita, evidenciando também inadequação de origem morfológica.

As poucas adequações evidenciam que, quando ocorre o fenômeno, a incidência é geralmente uniforme. No caso do texto 7, o aluno demonstra que o fenômeno na sua produção é isolado, estando a grafia dos vocábulos mas e nós livre da interferência da fala.

... começo a brigar (pret. perf., 4)

... acerto o pescosso... (pret. perf., 17)

... o menino fico em coma... (pret. perf. 17)

... ele chego na vuadora.(pret. perf., 28)

... é muita locura. (29)
... o meu outro amigo... (4)

... ai chegou eu separei... (17)

(sem adequações para o fenômeno)

Algo assim ou para refletir... (29) 
Ausência da letra u na escrita do ditongo decrescente -ou por influência da monotongação de /ow/ na fala. A monotongação caracteriza-se pela redução de um ditongo a uma vogal simples. Nos exemplos, ocorre em maior número na sílaba tônica de vocábulos verbais, no entanto, também se dá em sílaba pré-tônica de vocábulo nominal. As adequações indicam que a ocorrência não é uniforme nos textos, ou seja, no mesmo texto há erros e acertos, o que pode revelar que os alunos estão em processo intermediário de sensibilização sobre o fenômeno.

Quadro 16 - ASPECTOS REFERENTES A ACENTO

\begin{tabular}{|l|l|}
\hline \multicolumn{1}{|c|}{ INADEQUAÇÕES } & \multicolumn{1}{c|}{ ADEQUAÇÕES } \\
\hline $\begin{array}{l}\text {... derepente meu outro amigo... (17) } \\
\text {... derrepente começo a brigar... (4) } \\
\ldots \text { se mete emcrenca com você... (28) } \\
\ldots \text { purinquando eu nunca separei. (22) }\end{array}$ & ... não leva a nada. (17) \\
& ... brigar com o cara... (4) \\
& $\ldots$ vei para cima... (22)
\end{tabular}

Justaposição indevida de vocábulos, formando uma unidade lexical, o que configura palavra fonológica. Nos exemplos, um dos vocábulos é sempre preposição (de, em, por), elemento que facilita a ocorrência de palavra fonológica por não ter acento próprio, o que permite a prevalência do acento do vocábulo seguinte. É esse o fator que leva à ilusão de que os exemplos tratam-se de unidades lexicais. No caso de emcrenca ocorre ainda apagamento de início de vocábulo, o qual é substituído pela homófona preposição em. Neste último caso, é possível também que tenha havido um deslize ou o que se chama "erro não sistemático", comum na performance tanto oral quanto escrita.

As adequações indicam que o fenômeno que causa a incorreção está vinculado à preposição empregada: de, em e por podem contrair-se com o elemento seguinte, se este for artigo (de, em e por) ou pronome (somente de e em). Já as preposições a, com e para representam menor incidência de contração (à, comigo), sendo a preposição para contraída somente na oralidade: pra, pro, prum. Assim, é mais fácil que o fenômeno de palavra fonológica envolva preposições de contração recorrente.

... fui se para e a cabei tomano. (6)

... nunca mais ceparo nenhuma briga. (6)

Subdivisão indevida de unidade lexical em duas palavras morfológicas. Os vocábulos dos exemplos sugerem escrita baseada em pronúncia silabada, revelando estágio precário de reconhecimento dos limites morfológicos das palavras. No entanto, existem os vocábulos se e a, os quais, devido talvez a sua polissemia, podem ter levado o aluno a considerá-los unidades lexicais independentes, e não parte dos verbos separar e acabar. A grafia ceparo, embora esteja incorreta ortograficamente, corrobora a afirmação anterior, pois, ao não subdividir o vocábulo, o aluno demonstra que não reconhece a sílaba ce como uma unidade lexical independente. 


\begin{tabular}{|c|c|}
\hline ... sim ja vir o meu amigo... (4) & $\begin{array}{l}\text {... começo a brigar com o cara... (4) } \\
\text {... começaram a bater no cara... (4) }\end{array}$ \\
\hline \multicolumn{2}{|c|}{$\begin{array}{l}\text { Hipercorreção. Caracteriza-se pela aplicação desnecessária de uma regra } \\
\text { gramatical. Aparentemente, o aluno, para evitar grafar vi, o que julgaria ser } \\
\text { apagamento da desinência de infinitivo, acrescentou a letra r. Essa inadequação } \\
\text { revela estágio consciente de aprendizado, pois o aluno demonstra que está em } \\
\text { processo de autonomia quanto à correção da interferência da oralidade na escrita. } \\
\text { A grafia correta dos infinitivos brigar e bater corroboram a afirmação anterior. } \\
\text { Tratou-se, portanto, de erro não sistemático. }\end{array}$} \\
\hline $\begin{array}{l}\ldots \text { gostava das mesmas musicas... (7) } \\
\ldots \text { ele era muito rapido... (38) } \\
\ldots \text { acho ridiculo... (24) } \\
\ldots \text { violencia não leva a nada... (17) } \\
\ldots \text {.. é mais dificil de conter... (25) } \\
\ldots \text { mas tambem eu acho que ...(12) } \\
\ldots \text { um colega } \text { tambem... (16) } \\
\ldots \text { brigando com } \text { alguem... (20) } \\
\ldots \text { vai com voce... (28) } \\
\ldots \text { sempre } \text { estara do seu lado... (19) }\end{array}$ & $\begin{array}{l}\text { (sem adequações para o fenômeno) } \\
\text { (sem adequacõos para o fenômeno) } \\
\text { (sem adequações para o fenômeno) } \\
\text { (sem adequacões para o fenômeno) } \\
\text { (sem adequações para o fenômeno) } \\
\text {... quando ele mais precisa de você.... (12) } \\
\text { (sem adequações para o fenômeno) } \\
\text { (sem adequações para o fenômeno) } \\
\text { (sem adequacões para o fenômeno) } \\
\text {... seu amigo ta ali com você... (19) }\end{array}$ \\
\hline \multicolumn{2}{|c|}{$\begin{array}{l}\text { Ausência de acento gráfico obrigatório nos vocábulos proparoxítonos (musicas, } \\
\text { rapido, ridiculo), paroxítonos (violencia, dificil) e oxítonos (tambem, alguem, } \\
\text { voce, estara). Revela debilidade do aprendizado da regra de acentuação, talvez, } \\
\text { pela dificuldade de os alunos relacionarem o acento prosódico ao sistema que } \\
\text { organiza a distribuição dos diacríticos nos vocábulos. Em língua portuguesa, tal } \\
\text { organização é regida por economia e oposição: por economia, para marcar os } \\
\text { vocábulos em menor número; por oposição, para que o acento na palavra indique } \\
\text { que ela não deve ser lida como outra semelhante a ela pela terminação. Assim, } \\
\text { acentua-se todo o minoritário grupo das proparoxítonas em oposição ao } \\
\text { majoritário grupo das paroxítonas (por isso músicas, rápido e ridículo); por } \\
\text { economia, dentro do grupo das paroxítonas, acentua-se o pequeno número de } \\
\text { palavras cuja terminação seja diferente da terminação da maioria a, e, o e em (por } \\
\text { isso violência e difícil); e, por oposição, acentuam-se as palavras oxítonas } \\
\text { terminadas em a, e, o e em, para que não sejam lidas como paroxítonas (por isso } \\
\text { também, alguém, você, estará). Dessa forma, as inadequações contidas nos } \\
\text { exemplos ao lado indicam que não há sensibilização quanto à necessidade de } \\
\text { marcar essas palavras, pois não houve ao menos uso equivocado de acento, por } \\
\text { exemplo, uso de circunflexo no lugar de agudo. Essa observação descarta a } \\
\text { possibilidade de influência de debilidade relativa a acento prosódico, pois as } \\
\text { palavras dos exemplos, excetuando-se estará, fazem parte de vocabulário } \\
\text { cotidiano. As poucas adequações corroboram as afirmações anteriores, indicando } \\
\text { ainda que a acentuação correta também está relacionada à memorização das } \\
\text { palavras que mais se escrevem - como o exemplo do vocábulo você - o que } \\
\text { resulta em uma fotografia da palavra, acessada no momento de escrever. As } \\
\text { inadequações, portanto, são sistemáticas. }\end{array}$} \\
\hline $\begin{array}{l}\ldots \text { so se for muitos contra um... (13) } \\
\ldots \text { so que quem ceparou... (16) }\end{array}$ & $\begin{array}{l}\text { Eu já separei muitas briga... (13) } \\
\text { Eu já tive essa experiência... (16) }\end{array}$ \\
\hline
\end{tabular}


... estamos la discutindo... (16)

...ja de um colega tambem... (16)

Ausência de acento gráfico obrigatório em monossílabos tônicos terminados em o e a. Em língua portuguesa, a maioria dos monossílabos é átona, como os pronomes e as preposições, o que, na fala, resulta em dependência da tonicidade do vocábulo anterior ou posterior. O acento em monossílabos, como em só, lá e já, serve para indicar que deverão ter, na leitura, uma realização independente dos vocábulos circundantes. As adequações, circunscritas ao vocábulo já, podem indicar que os alunos, para acentuar, apoiam-se na memorização das palavras que mais escrevem - o mesmo caso de fotografia do item anterior - e menos na relação acento prosódico/ sistema de acentuação.

\subsection{Análise linguística da produção dos alunos bolivianos}

Segue a análise dos aspectos fonético-fonológicos da produção dos alunos bolivianos, referentes a vogal, consoante, sílaba e acento. Os trechos analisados foram agrupados de acordo ao tempo em que os alunos estudam na escola brasileira: 10 anos, 6 anos e 1 ano e meio.

\subsubsection{Análise linguística da produção dos alunos bolivianos há 10 anos na escola brasileira, alfabetizados em português}

Quadro 17 - ASPECTOS REFERENTES A VOGAIS

\begin{tabular}{|c|l|}
\hline \multicolumn{1}{|c|}{ INADEQUAÇÕES } & \multicolumn{1}{c|}{ ADEQUAÇÕES } \\
\hline ... um amigo aparece e vé... (39) & $\begin{array}{l}\text {... eu já defendi meu melhor amigo... (39) } \\
\text {... em um pré adolecente... (39) }\end{array}$ \\
\hline
\end{tabular}

Escolha indevida de acento agudo, em lugar de circunflexo, o qual deveria indicar vogal de timbre fechado em monossílabo tônico. O aluno, apesar de demonstrar ter conhecimento da regra de acentuação de monossílabos, aparenta não estabelecer relação entre acento gráfico e timbre vocálico. Tal incorreção pode ter origem na LM do aluno (espanhol), a qual não prevê variação de timbre para a vogal e, sendo esta sempre fechada e marcada com acento apenas para indicar posição em sílaba tônica. Embora se trate de um aluno boliviano alfabetizado em língua portuguesa na escola brasileira, a inadequação revela haver influência da LM, o que pode se justificar pela presença do espanhol no cotidiano doméstico. O registro, pelo tempo de exposição ao ensino formal da língua portuguesa, aponta para fossilização da debilidade em relacionar acento gráfico a timbre vocálico. No entanto, vale ressaltar que se trata de apenas uma incidência dentre todos os textos de alunos bolivianos alfabetizados na escola brasileira, o que revela a raridade da debilidade neste estágio do aprendizado. A grafia correta dos vocábulos já e pré corrobora a informação sobre o domínio da regra e sobre a debilidade relativa à diferenciação de timbre. 
Quadro 18 - ASPECTOS REFERENTES A CONSOANTES

\begin{tabular}{|c|c|}
\hline INADEQUAÇÕES & ADEQUAÇÕES \\
\hline $\begin{array}{l}\ldots \text { acho uma injustisa... (39) } \\
\ldots \text { dois adolecentes... (39) } \\
\ldots \text { eu ja tive uma esperiencia... (41) }\end{array}$ & $\begin{array}{l}\text { (sem adequações para o fenômeno) } \\
\text { (sem adequações para o fenômeno) } \\
\text { (sem adequações para o fenômeno) }\end{array}$ \\
\hline \multicolumn{2}{|c|}{$\begin{array}{l}\text { Neutralização da representação gráfica do fonema /s/, o qual, em língua } \\
\text { portuguesa, pode ser escrito como } \mathbf{s}, \mathbf{s s}, \mathbf{s c}, \mathbf{c}, \mathbf{c}, \mathbf{s c ̧}, \mathbf{x}, \mathbf{x c} \text { e } \mathbf{z} \text {. As inadequações são } \\
\text { idênticas às cometidas pelos alunos brasileiros: em injustisa há registro do } \\
\text { fonema /s/ por s intervocálico, ignorando que este passa a adquirir o valor de /z/; } \\
\text { em adolecentes há registro do fonema /s/ por c precedendo vogal e, o que é } \\
\text { previsto em língua portuguesa (inocente, docente), daí a oportunidade para o } \\
\text { engano gráfico; e em esperiencia, vocábulo que deve ser registrado experiência, } \\
\text { indicando que o fonema /s/ é parte do prefixo ex-, houve negligência desse } \\
\text { aspecto morfológico, por haver outros vocábulos em que o mesmo fonema } \\
\text { aparece como s quando em posição final de sílaba (espontâneo, esperar). } \\
\text { Portanto, em adolecentes e esperiencia há equívocos gráficos que o sistema } \\
\text { fonológico do português permite; e em injustisa, apesar de o sistema fonológico } \\
\text { não permitir registro de /s/ por s intervocálico, a inadequação parece ter origem } \\
\text { nas várias possibilidades de representação do fonema /s/. Descarta-se a } \\
\text { possibilidade de interferência da ortografia da LM do aluno nos equívocos, a qual } \\
\text { apresenta as formas injusticia, adolescentes e experiencia para os vocábulos em } \\
\text { questão, o que configuraria interferência positiva, caso ocorresse. A ausência de } \\
\text { adequações indica que o fenômeno, quando ocorre, apresenta normalmente } \\
\text { incidência uniforme. }\end{array}$} \\
\hline ... um menino tava mechendo... (41) & $\begin{array}{l}\text {... deixando o outro para tras... (41) } \\
\text {... machucando a mão... (41) }\end{array}$ \\
\hline \multicolumn{2}{|c|}{$\begin{array}{l}\text { Troca de } \mathbf{x} \text { por ch em registro de fonema } / \mathbf{f} / \text {. Ocorre pois a consoante } \mathbf{x} \text { e o } \\
\text { dígrafo ch concorrem na representação do fonema } / \boldsymbol{\int} / \text {, sendo inadequação } \\
\text { recorrente de aprendizes de língua portuguesa como LM. Descarta-se aqui a } \\
\text { interferência de aspecto fonológico da língua materna dos alunos bolivianos, pois, } \\
\text { em espanhol, } \mathbf{x} \text { e ch não concorrem no registro dos mesmos fonemas, sendo o } \\
\text { primeiro representante de } / \mathbf{k s} / \text {, e o segundo de } / \mathbf{t} / \text {. As adequações deixando e } \\
\text { machucando podem indicar memorização das grafias ou domínio da regra de uso } \\
\text { de } \mathbf{x} \text { após ditongo decrescente, o que, por oposição, levaria a escrever com ch os } \\
\text { vocábulos que não carregam esse ditongo - como machucar - justificando } \\
\text { também a grafia incorreta mechendo. }\end{array}$} \\
\hline ... na ora do recreio... (41) & ... na hora da saida... (41) \\
\hline \multicolumn{2}{|c|}{$\begin{array}{l}\text { Ausência de } \mathbf{h} \text { obrigatório em posição inicial de vocábulo. Ocorre devido à } \\
\text { migração para a escrita da não realização oral da consoante } \mathbf{h} \text { quando esta inicia } \\
\text { palavra. É aspecto que figura tanto na fonologia do português quanto do } \\
\text { espanhol, pois nas duas línguas há palavras iniciadas por h etimológico, o qual } \\
\text { permanece em vocábulos para indicar a origem latina, mas não é pronunciado. }\end{array}$} \\
\hline
\end{tabular}




\begin{tabular}{|c|c|}
\hline \multicolumn{2}{|c|}{$\begin{array}{l}\text { Em espanhol contam-se em número maior (hora, huerta, hemorragia, haber, } \\
\text { hacer, hipnosis, hierro, higo, harina, dentre outras), pois muitas das equivalentes, } \\
\text { em português, não pertencem ao grupo por possuírem } \mathbf{f} \text { no lugar do h inicial } \\
\text { (fazer, ferro, figo, farinha, forca, dentre outras). O exemplo hora é um dos } \\
\text { vocábulos que coincidem nas duas línguas, tanto ortograficamente quanto no tipo } \\
\text { de incorreção dos aprendizes. O registro correto hora indica que o erro não é } \\
\text { sistemático, mas devido a lapso do aluno. }\end{array}$} \\
\hline ... acho pessimo... (40) & (sem adequações para o fenômeno) \\
\hline \multicolumn{2}{|c|}{$\begin{array}{l}\text { Ausência de acento gráfico obrigatório em vocábulo proparoxítono. A ocorrência } \\
\text { de uma única incorreção impossibilita afirmações sobre a origem do erro, } \\
\text { podendo revelar tanto distração, quanto debilidade no aprendizado da regra de } \\
\text { acentuação, talvez, pela dificuldade de o aluno relacionar o acento prosódico ao } \\
\text { sistema que organiza a distribuição dos diacríticos nos vocábulos em língua } \\
\text { portuguesa. A regra das proparoxítonas em português e em espanhol é a mesma, } \\
\text { sendo previsto acento para todas, diferenciando-se apenas que, em português, há } \\
\text { a possibilidade de uso do acento circunflexo para marcar variação de timbre } \\
\text { vocálico, inexistente em espanhol. Assim, descarta-se a interferência de aspecto } \\
\text { da LM do aluno boliviano, pois não alteraria o resultado da inadequação em } \\
\text { questão, já que nas duas línguas são coincidentes. }\end{array}$} \\
\hline ... quando eu chegei... (39) & (sem adequações para o fenômeno) \\
\hline \multicolumn{2}{|c|}{$\begin{array}{l}\text { Ausência de } \mathbf{u} \text { em registro de dígrafo representante de consoante oclusiva /g /. É } \\
\text { obrigatório antes de /e/ ou /i/, tanto em português quanto em espanhol, para que a } \\
\text { letra } \mathbf{g} \text { não seja lida como consoante fricativa /3 /. A existência de uma única } \\
\text { ocorrência revela que a inadequação, resíduo da fase de alfabetização, é rara no } \\
\text { estágio em que o aluno se encontra. }\end{array}$} \\
\hline ... cuando ele tava perdendo... (41) & ... queria me dar o primeiro soco... (41) \\
\hline \multicolumn{2}{|c|}{$\begin{array}{l}\text { Troca de q por c na grafia da consoante oclusiva formadora de /kw/. Ocorre por } \\
\text { interferência da LM do aluno boliviano, a qual prevê uso de c para grafar /kw/, e } \\
\text { q somente para grafar som de /k/ antes de vogais /e/ ou /i/. Assim, em espanhol } \\
\text { há as grafias cuero e cuando, indicando que o u deve ser pronunciado; e queso ou } \\
\text { quilo, indicando que o u não deve ser pronunciado, ou seja, faz parte do dígrafo } \\
\text { qu. Em português, essa distinção não ocorre, sendo o q utilizado tanto para /kw/ } \\
\text { quanto para /k/ antes das vogais /e/ ou /i/. Assim, temos em língua portuguesa os } \\
\text { vocábulos quando, liquidificador, cinquenta, queijo e quilo, por exemplo, } \\
\text { cujas grafias não indicam a pronúncia que as diferencia - já que o trema, } \\
\text { responsável por isso, foi aposentado na reforma ortográfica ocorrida nesta } \\
\text { década. A inadequação do aluno revela que, apesar de ser alfabetizado na escola } \\
\text { brasileira, apresenta interferência fossilizada da sua LM, com a qual mantém } \\
\text { contato, certamente, em ambiente doméstico. Caracteriza-se como fossilizada } \\
\text { pelo tempo em que o aluno encontra-se em contato com o ensino formal da língua } \\
\text { portuguesa, e também pela presença do registro tava no mesmo trecho, o que } \\
\text { indica que houve aquisição de aspectos inclusive da oralidade da língua } \\
\text { portuguesa, enquanto que o cuando permaneceu em espanhol. A adequação }\end{array}$} \\
\hline
\end{tabular}




\begin{tabular}{|l|l|}
\hline \multicolumn{2}{|c|}{ queria corrobora com a análise no sentido de poder ser também interferência } \\
positiva do espanhol, já que neste idioma o vocábulo é grafado igualmente. \\
\hline Faleu!! (valeu) (42) & ... eu já vi... (42) \\
\hline & \\
& $\begin{array}{l}\text { Troca de consoante labiodental sonora v por surda f, na escrita, por transferência } \\
\text { de desvozeamento ocorrido na fala. Trata-se de inadequação que pode ser resíduo } \\
\text { da fase de alfabetização ou reflexo de problema fonoaudiológico do aluno. No } \\
\text { entanto, a grafia correta do vocábulo vi pode indicar que a incorreção tratou-se de } \\
\text { lapso ou que o desvozeamento do fonema /f/ ocorre com maior facilidade antes } \\
\text { da vogal aberta /a/. }\end{array}$ \\
\hline
\end{tabular}

Quadro 19 - ASPECTOS REFERENTES A SILABA

\begin{tabular}{|c|c|}
\hline INADEQUAÇÕES & ADEQUAÇÕES \\
\hline ... e nois brigamos... (41) & $\begin{array}{l}\ldots \text { deixando o outro para tras. }(41) \\
\ldots . \text { me segurar por tras... }(41)\end{array}$ \\
\hline \multicolumn{2}{|c|}{$\begin{array}{l}\text { Acréscimo indevido de semivogal i ao vocábulo, causado por ditongação de } \\
\text { vogal o ocorrida na fala. Trata-se de fenômeno idêntico ao encontrado nos textos } \\
\text { dos alunos brasileiros, evidenciando que o aluno boliviano considerou aspecto } \\
\text { fonológico do português para tomar as decisões relativas à grafia do vocábulo. A } \\
\text { ditongação, muito frequente no português oral (vide /majs/, /vejs/ e /fejs/, para } \\
\text { mas, vez e fez), a qual aponta para a presença de ditongos como aspecto } \\
\text { distintivo entre português e espanhol: a primeira possui mais vocábulos nominais } \\
\text { com esse tipo de encontro vocálico (bandeira, bandera; parceiro, parcero; dois, } \\
\text { dos; outro, otro; ouro, oro; queijo, queso); e a segunda tem frequência de } \\
\text { ditongos nas formas conjugadas dos verbos (quero, quiero; posso, puedo; conto, } \\
\text { cuento; encontro, encuentro). Essa característica torna distante a possibilidade de } \\
\text { interferência da LM do aluno boliviano na grafia ditongada nois. } \\
\text { As adequações, desconsiderando a falta de acentuação, podem indicar que o } \\
\text { fenômeno da ditongação incide em vocábulo de maior uso, como é o caso de nós. } \\
\text { Além disso, a escrita sem ditongação da palavra trás pode ter interferência } \\
\text { positiva da LM do aluno, cujo vocábulo equivalente atrás também não é } \\
\text { ditongado. }\end{array}$} \\
\hline
\end{tabular}

Quadro 20 - ASPECTOS REFERENTES A ACENTO

\begin{tabular}{|c|c|}
\hline INADEQUAÇÕES & ADEQUAÇÕES \\
\hline ... mechendo com migo... (41) & $\ldots$ ia brigar comigo... (41) \\
\hline \multicolumn{2}{|c|}{ (4rafia bipartida de vocábulo, causada por interferência de aspecto oral da LM do } \\
aluno boliviano. Em espanhol, o vocábulo equivalente é conmigo, escrito de
\end{tabular}




\begin{tabular}{|c|c|}
\hline \multicolumn{2}{|c|}{$\begin{array}{l}\text { forma una, mas realizado oralmente com distinção clara dos fonemas } / \mathbf{n} / \text { e } / \mathbf{m} / \\
\text { criando a sensação auditiva de dois vocábulos, fenômeno chamado palavra } \\
\text { fonológica. Aparentemente, essa inadequação migrou para a escrita do vocábulc } \\
\text { em língua portuguesa. No entanto, o fato de o aluno ter concluído a sílaba de fina } \\
\text { nasal (com) utilizando m, e não n, demonstra que ele já adquiriu o conhecimentc } \\
\text { de que a grafia da nasalização final em português é diferente da grafia em } \\
\text { espanhol. A incorreção demonstra estágio em que o aluno está eliminando a a } \\
\text { interferência da sua LM da escrita em língua portuguesa, de uma palavra que } \\
\text { certamente, faz parte do vocabulário doméstico oral espanhol dos familiares. A } \\
\text { adequação comigo corrobora a afirmação de que a incorreção está em estágio de } \\
\text { eliminação. }\end{array}$} \\
\hline $\begin{array}{l}\ldots \text { ele } j a \text { o defende... (39) } \\
\text { Eu ja defendi meu melhor amigo... (39) } \\
\ldots \text { eu ja tive uma esperiencia... (41) } \\
\text {... me segurar por tras... (41) } \\
\text {... fiquei } l a . . .(41)\end{array}$ & $\begin{array}{l}\text {... batam em um pré adolecente... (39) } \\
\text { (sem adequações para o fenômeno) } \\
\text { (sem adequações para o fenômeno) } \\
\text { (sem adequações para o fenômeno) }\end{array}$ \\
\hline \multicolumn{2}{|c|}{$\begin{array}{l}\text { Ausência de acento gráfico obrigatório em monossílabos tônicos terminados em } \\
\text { a. O acento em monossílabos, como em já, lá e trás, serve para indicar que } \\
\text { deverão ter, na leitura, uma realização independente dos vocábulos circundantes } \\
\text { O equívoco é semelhante aos cometidos pelos alunos brasileiros, e também } \\
\text { descartam a possibilidade de influência de debilidade relativa a acento prosódico } \\
\text { pois as palavras dos exemplos fazem parte de vocabulário cotidiano. A debilidade } \\
\text { estaria em relacionar o acento da fala à forma de organizar as marcas de acento na } \\
\text { escrita. A presença de uma única adequação relacionada à acentuação de } \\
\text { monossílabos tônicos, pré, evidencia que a incidência do equívoco está } \\
\text { circunscrita sobretudo aos monossílabos terminados em -a, pois esses apresentam } \\
\text { a realização dos tônicos e dos átonos aproximada. Assim, a tonicidade do } \\
\text { monossílabos terminados em -e, em comparação com os terminados em -a, } \\
\text { algo mais fácil de definir, o que pode justificar a acentuação correta de pré } \\
\text { nenhuma acentuação dos vocábulos terminados em -a. }\end{array}$} \\
\hline
\end{tabular}

\subsubsection{Análise linguística da produção dos alunos bolivianos há 6 anos na escola brasileira, alfabetizados em espanhol na escola boliviana}

\section{Quadro 21 - ASPECTOS REFERENTES A VOGAIS}

\begin{tabular}{|l|l|}
\hline \multicolumn{1}{|c|}{ INADEQUAÇÕES } & \multicolumn{1}{|c|}{ ADEQUAÇÕES } \\
\hline $\begin{array}{l}\text { Eu já vivi esa emoção, mais não } \boldsymbol{e} \text { boa... (43) } \\
\ldots \text { não vou ficar para sempre com ele } \boldsymbol{e} \text { ele tem } \\
\text { de a comprende a ser consiente. (43) }\end{array}$ & (sem adequações para o fenômeno) \\
\hline
\end{tabular}

Acentuação indevida para indicar tonicidade ou abertura de timbre vocálico do monossílabo e. A inadequação pode indicar interferência da LM do aluno boliviano, a qual não prevê variação de timbre vocálico, desconsiderando-a como traço distintivo. Assim, /e/ e / / / soam equivalentes, afetando o registro escrito do que deveria ser a $3^{\mathrm{a}}$ pessoa do singular do presente do indicativo do 


\begin{tabular}{|c|c|}
\hline \multicolumn{2}{|c|}{$\begin{array}{l}\text { verbo ser (primeiro exemplo), revelando, desse modo, inadequação } \\
\text { morfológica, pois o registro passou a indicar graficamente a conjunção aditiva e } \\
\text { (a qual, pelo mesmo fenômeno, não foi grafada no segundo exemplo). O fato de } \\
\text { haver os dois registros de e com diferenciação morfológica afeta a decisão do } \\
\text { aluno, assim como ocorre com os brasileiros, no entanto, por ter sido } \\
\text { alfabetizado em espanhol, e por essa língua ter presença no seu ambiente } \\
\text { doméstico, a causa da inadequação tende a ser mais fonológica que } \\
\text { morfológica. A julgar pela ausência de adequações sobre o fenômeno no } \\
\text { restante do texto, e pelo tempo de escolarização em português (6 anos), pode-se } \\
\text { caracterizar o erro como fossilizado, o que permite afirmar que os problemas } \\
\text { relativos a timbre vocálico constituem área fossilizável para hispanofalantes } \\
\text { aprendizes de língua portuguesa. }\end{array}$} \\
\hline Eu fiz errado $\boldsymbol{i}$ deveria ter separado... (43) & (sem adequações para o fenômeno) \\
\hline \multicolumn{2}{|c|}{$\begin{array}{l}\text { Troca de e por i, em registro gráfico. Pode ter sido causada por dois fatores: } \\
\text { alçamento, na fala, da vogal /e/ átona - traço fonológico presente na língua } \\
\text { portuguesa; ou influência do vocábulo em espanhol y, o qual se realiza } \\
\text { foneticamente como /i/, tal qual na oralidade do português. Considerando-se o } \\
\text { restante do texto (vide item anterior sobre o mesmo texto } 43 \text { ), é possível } \\
\text { concluir que o equívoco é resultado de ambos os fenômenos. Embora } \\
\text { alfabetizado em espanhol e tendo presença dessa língua no ambiente doméstico, } \\
\text { o aluno encontra-se também sob influência de ambiente lusófono oral, quer por } \\
\text { tempo de escolarização em português, quer por convívio social com brasileiros } \\
\text { e com a cultura transmitida em português. Por isso considerou elemento da } \\
\text { fonologia dessa língua para a grafia da conjunção aditiva e. }\end{array}$} \\
\hline ... hoje não confiu mas em ninguém... (44) & (sem adequações para o fenômeno) \\
\hline \multicolumn{2}{|c|}{$\begin{array}{l}\text { Troca de o por u, na escrita, influenciada por alçamento, na fala, da vogal /o/ } \\
\text { em posição átona. O ambiente fonológico pós-tônico de /o/, além de alçar a } \\
\text { vogal, semivocaliza-a, fazendo com que o encontro vocálico final seja realizado } \\
\text { como ditongo /iw/. Assim como o exemplo anterior de alçamento vocálico, a } \\
\text { inadequação indica que o aluno considerou elemento da fonética da língua } \\
\text { portuguesa para o registro gráfico da forma verbal confio, sem interferência de } \\
\text { aspecto da LM espanhola. }\end{array}$} \\
\hline
\end{tabular}

\section{Quadro 22 - ASPECTOS REFERENTES A CONSOANTES}

Eu já vivi esa emoção... (43)

....ele tem de a comprende a ser consiente... (43) (sem adequações para o fenômeno)

(sem adequações para o fenômeno)

Ausência de segundo $\mathbf{s}$ na representação gráfica do fonema /s/ em posição intervocálica, o qual, na incorreção, passou a ter o valor de /z/. Pode ser causado por interferência da LM do aluno boliviano, pois, em espanhol, além de o 


\begin{tabular}{|c|c|}
\hline \multicolumn{2}{|c|}{$\begin{array}{l}\text { fonema /s/ intervocálico poder ser representado graficamente por apenas um } \mathbf{s} \text {, o } \\
\text { aluno também pode ter utilizado o vocábulo em sua LM, pois o equivalente a } \\
\text { essa em espanhol é esa. No entanto, não se descarta a possibilidade de a } \\
\text { incorreção ter a mesma causa das idênticas inadequações, iso e asim, cometidas } \\
\text { pelos alunos brasileiros: neutralização da representação gráfica do fonema /s/, o } \\
\text { qual, em língua portuguesa, pode ser escrito como } \mathbf{s}, \mathbf{s s , ~} \mathbf{s c}, \mathbf{c}, \mathbf{c}, \mathbf{s c ̧ , ~} \mathbf{x}, \mathbf{x c} \text { e } \mathbf{z} \text {. O } \\
\text { mesmo fenômeno de neutralização ocorre na grafia consiente, em que ocorre a } \\
\text { ausência de c no dígrafo sc representante do fonema } / \mathbf{s} / \text {. O equívoco descarta } \\
\text { interferência da ortografia da LM do aluno boliviano, a qual prevê vocábulo } \\
\text { homógrafo ao do português, o que configuraria influência positiva caso } \\
\text { ocorresse. Credita-se a incorreção à homofonia entre sc e } \mathbf{s} \text { antecedido de } \\
\text { consoante nasal n. A ausência de adequações - e considerando o tempo de } \\
\text { escolarização em português - pode indicar área fossilizada. }\end{array}$} \\
\hline $\begin{array}{l}\text {... ele tem de a comprende a ser consiente. } \\
\text { (43) }\end{array}$ & $\begin{array}{l}\text {... deveria ter separado... (43) } \\
\ldots . \text { eu não vou ficar para sempre com } \\
\text { ele... (43) }\end{array}$ \\
\hline \multicolumn{2}{|c|}{$\begin{array}{l}\text { Apagamento da desinência de infinitivo }-\mathbf{r} \text {, por influência do apagamento da } \\
\text { consoante vibrante /r/. Constitui-se como traço da fonologia do português do } \\
\text { Brasil, evidência de que o aluno boliviano estava considerando elementos do } \\
\text { português ao tomar as decisões da grafia que o levaram à incorreção - a qual é } \\
\text { idêntica às cometidas pelos alunos brasileiros. O apagamento da primeira vogal } \\
\text { e do vocábulo comprêender, que ocorre pela dominância da vogal nasal /ẽ/ } \\
\text { sobre a vogal oral /e/ em ambiente fonológico átono, também configura } \\
\text { transferência para a escrita de fenômeno da fala. No entanto, as adequações ter } \\
\text { e ficar demonstram que o apagamento da desinência de infinitivo não é erro } \\
\text { sistemático, e limitou-se à construção complexa que o aluno tentou fazer, a qual } \\
\text { talvez fosse: ele tem que compreender e ser consciente ou ele tem que aprender } \\
\text { a ser consciente. }\end{array}$} \\
\hline ... algumas pessoas dissem que ... (44) & $\begin{array}{l}\text {... relação entre amizades... (44) } \\
\text { As vezes a pessoa finge ser seu amigo... } \\
(44)\end{array}$ \\
\hline \multicolumn{2}{|c|}{$\begin{array}{l}\text { Representação indevida do fonema /z/ por ss, registro não previsto no sistema } \\
\text { ortográfico da língua portuguesa. A inadequação é idêntica à dos alunos } \\
\text { brasileiros, mas pode apresentar uma causa distinta: a não diferenciação entre a } \\
\text { fricativa vozeada /z/ e a não vozeada /s/, traço da LM do aluno boliviano. Outra } \\
\text { causa, e esta aproxima a dificuldade dos alunos bolivianos da dos brasileiros, } \\
\text { tem origem morfológica, e está na irregularidade das formas conjugadas do } \\
\text { verbo dizer, as quais são semelhantes no pretérito perfeito do indicativo e no } \\
\text { futuro do subjuntivo, e se confundem com a do presente quando o aluno não } \\
\text { diferencia /z/ de /s/. As adequações amizades e vezes, em que há representação } \\
\text { correta do fonema /z/, indicam que a causa do equívoco é relativa à } \\
\text { irregularidade da conjugação do verbo dizer. }\end{array}$} \\
\hline
\end{tabular}


Quadro 23 - ASPECTOS REFERENTES A SÍLABA

\begin{tabular}{|c|c|}
\hline INADEQUAÇÕES & ADEQUAÇÕES \\
\hline ... por causa de bestera ... (44) & (sem adequações para o fenômeno) \\
\hline \multicolumn{2}{|c|}{$\begin{array}{l}\text { Ausência da letra i na escrita do ditongo decrescente -ei por influência da } \\
\text { monotongação de /ej/ na fala. A monotongação, caracterizada pela redução de } \\
\text { um ditongo a uma vogal simples, ocorre, neste caso, por processo de facilitação } \\
\text { e economia articulatórias. Na passagem da penúltima sílaba /tej/ para a última } \\
\text { /ra/, o falante, para manter-se constante na posição articulatória média, evita a } \\
\text { variação vogal média/e/>semivogal alta/j/>consoante média/r /, eliminando a } \\
\text { semivogal alta /j/. O fenômeno da fala migrou para a escrita do aluno boliviano, } \\
\text { tal qual ocorre com os brasileiros, evidenciando que o aprendiz estrangeiro, a } \\
\text { respeito desta incorreção, está sob influência dos elementos fonológicos da } \\
\text { língua portuguesa aos quais se encontra exposto. No entanto, vale considerar } \\
\text { que, na LM do aluno boliviano, o processo de monotongação de ditongos } \\
\text { decrescentes acha-se bastante incorporado à ortografia, sobretudo em vocábulos } \\
\text { não verbais, como poco, bandera, primera, dinero e loca, equivalentes aos } \\
\text { pouco, bandeira, primeira, dinheiro e louca, que, em língua portuguesa têm } \\
\text { conservado o ditongo. Tal aspecto da LM do aluno não se descarta como } \\
\text { influência. }\end{array}$} \\
\hline Eu já vivi esa emoção mais não e boa... (43) & (sem adequações para o fenômeno) \\
\hline \multicolumn{2}{|c|}{$\begin{array}{l}\text { Acréscimo indevido de semivogal i ao vocábulo, causado por ditongação de } \\
\text { vogal a ou e ocorrida na fala. A ditongação, no caso dos exemplos, é facilitada } \\
\text { pelo ambiente fonológico circundante às vogais. Trata-se de fenômeno idêntico } \\
\text { ao encontrado nos textos dos alunos brasileiros, evidenciando que o aluno } \\
\text { boliviano considerou aspectos fonológico e morfológico do português para } \\
\text { tomar as decisões relativas à grafia do vocábulo, fatores que descartam a } \\
\text { interferência da LM espanhola. }\end{array}$} \\
\hline
\end{tabular}

Quadro 24 - ASPECTOS REFERENTES A ACENTO

\begin{tabular}{|c|c|}
\hline ... ajúda sempre que puder... (43) & Agora amigo só amigo separa... (43) \\
\hline \multicolumn{2}{|c|}{$\begin{array}{l}\text { Acentuação indevida de vocábulo paroxítono terminado em a. A inadequação } \\
\text { não ocorre por interferência da regra de acentuação da LM do aluno boliviano, a } \\
\text { qual também não prevê acento para equivalente ayuda por tratar-se de } \\
\text { paroxítona (grave, em espanhol) terminada em vogal. O aluno, ao decidir-se por } \\
\text { acentuar a palavra ajuda, considerou a acentuação fonética, e não a ortográfica, } \\
\text { fato esse que pode ter origem tanto na prosódia do português quanto na do } \\
\text { espanhol. As adequações agora e separa indicam que o equívoco não é } \\
\text { sistemático. }\end{array}$} \\
\hline
\end{tabular}




\subsubsection{Análise linguística da produção dos alunos bolivianos há 1 ano e meio na escola brasileira, alfabetizados em espanhol na escola boliviana}

Quadro 25 - ASPECTOS REFERENTES A VOGAIS

\begin{tabular}{|l|l|}
\hline \multicolumn{1}{|c|}{ INADEQUAÇÕES } & \multicolumn{1}{c|}{ ADEQUAÇÕES } \\
\hline $\begin{array}{l}\text {... quando agen brigar } \boldsymbol{u} \text { amigo tem que separar } \\
\text { a briga... (45) } \\
\ldots \text { da um voadora pra } \boldsymbol{u} \text { outro... (45) }\end{array}$ & $\begin{array}{l}\text {... eu acho que... (45) } \\
\text {... pra outro... (45) }\end{array}$ \\
\hline
\end{tabular}

Troca de o por $\mathbf{u}$ em registro escrito, motivada pelo alçamento vocálico de /o/ para /u/ ocorrido na fala. $\mathrm{O}$ alçamento corre pela natureza átona do artigo definido o, o qual se torna dependente fonologicamente do vocábulo anterior ou posterior. No primeiro exemplo, a vogal $\mathbf{o}$ é alçada, e sua realização se dá como um /u/, podendo formar, na fala, sílaba com a consoante final $-\mathbf{r}$ do vocábulo brigar. No segundo exemplo, ocorre alçamento devido à semivocalização da vogal a do vocábulo precedente pra (para), criando a palavra fonológica /praw/, a qual foi grafada pra $\boldsymbol{u}$. Trata-se de fenômeno da fonologia do português, evidenciando que o aluno boliviano encontra-se em bastante contato com a oralidade desta língua, incorporando-a em seu repertório. As adequações acho e outro, as quais possuem vogal final geralmente alçada no registro oral, indicam que o equívoco se restringe ao artigo $\mathbf{0 .}$

... un desenho que $\boldsymbol{e}$ do melhor amigo... (46)

... o amigo tem que separar a briga $e$ não (sem adequações para o fenômeno) chegar e da um voadora... (45)

Equívoco em registro escrito de variação de timbre vocálico de monossílabo. A inadequação pode indicar interferência da LM do aluno boliviano, a qual não prevê variação de timbre vocálico, desconsiderando-a como traço distintivo. Assim, /e/ e / $\varepsilon$ / soam equivalentes, afetando, no primeiro exemplo, o registro escrito do que deveria ser a $3^{a}$ pessoa do singular do presente do indicativo do verbo ser, acentuado, indicando timbre aberto; e, no segundo exemplo, o que deveria ser conjunção aditiva, sem acento, indicando timbre fechado. $\mathrm{O}$ fato de haver os dois registros de e com diferenciação morfológica afeta a decisão do aluno, assim como ocorre com os brasileiros, no entanto, por ter sido alfabetizado em espanhol, e por essa língua ter presença no seu ambiente doméstico, a causa da inadequação tende a ser mais fonológica que morfológica. Vale lembrar que, no segundo exemplo, o aluno utiliza acento, o que, apesar de constituir equívoco, indica que já há sensibilização quanto à existência da vogal e acentuada. Além disso, há no restante do trecho a grafia do verbo dar com apagamento da desinência de infinitivo, traço da fala dos brasileiros, indicando que o aluno encontra-se influenciado por aspectos do português, e sensível a eles. Ambos os exemplos não indicam fossilização, sobretudo por seus autores estarem há apenas um ano e meio em contato com o aprendizado formal do português. Contudo, é evidente que a produção, no segundo exemplo, demonstra maior apropriação da fonologia do português. A adequação "chegar e da uma voadora" deixa ver que o aluno está em fase de alternância quanto à incidência do fenômeno. 


\begin{tabular}{|c|c|}
\hline ... pedir disculpa ... (45) & ... pedir disculpa... (45) \\
\hline \multicolumn{2}{|c|}{$\begin{array}{l}\text { Troca de e por i em registro escrito, motivada pelo alçamento vocálico de /e/ } \\
\text { para /i/ ocorrido na fala. O alçamento é facilitado pelo ambiente fonético } \\
\text { circundante à vogal /e/. Tanto a consoante precedente /d/ quanto a seguinte /s/ } \\
\text { são alveolares, ou seja, articuladas em ponto alto do aparelho fonador. Isso faz } \\
\text { com que, por economia de mudança de posição articulatória, a vogal /e/ seja } \\
\text { alçada para um ponto mais alto, próximo à altura alveolar, sendo realizada } \\
\text { como a vogal alta /i/, daí a origem do equívoco gráfico. Esta inadequação, } \\
\text { comum na fala dos brasileiros, demonstra que o aluno boliviano está sujeito e } \\
\text { atento aos elementos fonológicos do português, descartando-se, para este caso, } \\
\text { interferência de sua LM. A adequação pedir também contém vogal /e/ } \\
\text { geralmente alçada no registro oral, no entanto foi escrita corretamente. Isso } \\
\text { pode indicar que a inadequação, além de estar relacionada aos pontos de } \\
\text { articulação do aparelho fonador, também pode ser causada pela existência de } \\
\text { vocábulos iniciados por dis-, como disposiçãa, dispensar ou discutir. }\end{array}$} \\
\hline $\begin{array}{l}\text {... ten un desenho ... (46) } \\
\ldots \text { o de baixo ten un ... (46) } \\
\ldots \text { que estan brigando... (46) } \\
\ldots \text { brigando con... (46) } \\
\ldots \text { bati en ela... (46) }\end{array}$ & (sem adequações para o fenômeno) \\
\hline \multicolumn{2}{|c|}{$\begin{array}{l}\text { Registro de nasalização com interferência da LM do aluno, a qual somente } \\
\text { utiliza }-\mathbf{n} \text { em final de vocábulo. Os equívocos evidenciam que o registro da } \\
\text { nasalização, para o autor destes exemplos, não considera a fonologia do } \\
\text { português, para a qual praticamente inexiste o registro de nasalização de final de } \\
\text { vocábulo em -n. Trata-se de equívoco bastante presente na escrita de } \\
\text { aprendizes hispanofalantes em início da aquisição da língua portuguesa, os } \\
\text { quais, neste estágio, são fossilizáveis. Esses casos são de transferência direta da } \\
\text { escrita da LM, e a ausência de adequações indica que o aluno não iniciou o } \\
\text { processo de abandono desse tipo de transferência. }\end{array}$} \\
\hline
\end{tabular}

Quadro 26 - ASPECTOS REFERENTES A CONSOANTES

\begin{tabular}{|c|c|}
\hline INADEQUAÇÕES & ADEQUAÇÕES \\
\hline $\begin{array}{l}\ldots . \text { o amigo tem que separar a briga é não } \\
\text { chegar e } \boldsymbol{d} a \text { um voadora... (45) }\end{array}$ & $\begin{array}{l}\ldots \text { tem que separar... }(45) \\
\ldots \text { chegar e da... (45) } \\
\ldots \text { pedir disculpa... (45) }\end{array}$ \\
\hline \multicolumn{2}{|c|}{$\begin{array}{l}\text { Apagamento da desinência de infinitivo }-\mathbf{r} \text {, por influência do apagamento da } \\
\text { consoante vibrante } / \mathbf{r} / \text {. O apagamento da vibrante } / \mathbf{r} / \text { é traço da fonologia do } \\
\text { português do Brasil, inexistente na oralidade do espanhol. No caso do } \\
\text { monossílabo dar, o apagamento da desinência }-\mathbf{r} \text { pode levar à semelhança com }\end{array}$} \\
\hline
\end{tabular}




\begin{tabular}{|c|c|}
\hline \multicolumn{2}{|c|}{$\begin{array}{l}\text { a sua forma no presente dá. No entanto, como não houve aplicação da regra de } \\
\text { acentuação de monossílabos tônicos, o equívoco pode ter origem na semelhança } \\
\text { com a forma } \boldsymbol{d a} \text {, contração da preposição } \boldsymbol{d e} \text { com artigo } \boldsymbol{a} \text {, vocábulo mais } \\
\text { presente no repertório escrito dos alunos. Trata-se de equívoco idêntico ao dos } \\
\text { alunos brasileiros, o que evidencia que o aluno boliviano estava sob influência } \\
\text { de elementos do português ao tomar as decisões de grafia que levaram à } \\
\text { incorreção. } \\
\text { As adequações separar, chegar e pedir demonstram que o equívoco está } \\
\text { circunscrito ao verbo dar e a sua semelhança, na forma oral, com a contração } \\
\text { preposição de + artigo a. }\end{array}$} \\
\hline Acho que o da sima ten un desenho... (46) & (sem adequações para o fenômeno) \\
\hline \multicolumn{2}{|c|}{$\begin{array}{l}\text { Troca de } \mathbf{c} \text { por } \mathbf{s} \text { em registro de fonema /s/ quando este ocupa posição inicial de } \\
\text { vocábulo. Em língua portuguesa e na LM do aluno, o fonema /s/ em tal posição } \\
\text { e antecedendo vogal /e/ pode ser representado por } \mathbf{s} \text { ou } \mathbf{c} \text {, o que possivelmente } \\
\text { causou o equívoco - muito frequente na produção de alunos brasileiros também. } \\
\text { A ausência de adequações não permite dizer se o equívoco é sistemático ou não. }\end{array}$} \\
\hline Eu $y \boldsymbol{a}$ fez isso... (46) & (sem adequações para o fenômeno) \\
\hline \multicolumn{2}{|c|}{$\begin{array}{l}\text { Troca de } \mathbf{j} \text { por } \mathbf{y} \text { em registro escrito do fonema /z/, causada por interferência da } \\
\text { grafia da LM do aprendiz. O aluno grafou a palavra em espanhol (transferência } \\
\text { direta da LM) o que pode ter ocorrido por ele associar a realização do fonema } \\
\text { /3/ como sendo mais próxima à y que a j, pois esta última, em espanhol, possui } \\
\text { valor de /x/, como na palavra aprendisaje. Trata-se, portanto, de equívoco } \\
\text { frequente em estágio inicial de aquisição da língua portuguesa por } \\
\text { hispanofalantes, a julgar também pela falta de concordância de sujeito e verbo } \\
\text { no trecho, bastante comum nas produções desses aprendizes. O uso de y } \\
\text { constitui inadequação não fossilizável, já que a inexistência dessa letra em } \\
\text { vocábulos da língua portuguesa (excetuando-se os estrangeiros } \\
\text { aportuguesados), em pouco tempo, estabelece para o aluno que tal registro não é } \\
\text { uma opção. Vale notar que tal equívoco não apareceu nas produções dos alunos } \\
\text { bolivianos com } 6 \text { ou } 10 \text { anos de escolarização no Brasil, o que corrobora a } \\
\text { afirmação anterior. } \\
\text { A ausência de adequações e mesmo de repetição da inadequação não permitem } \\
\text { dizer se o equívoco é sistemático ou não. }\end{array}$} \\
\hline ... cuando a minha hirman... (46) & (sem adequações para o fenômeno) \\
\hline \multicolumn{2}{|c|}{$\begin{array}{l}\text { Troca de q por c na grafia da consoante oclusiva formadora de /kw/. Ocorre por } \\
\text { interferência da LM do aluno boliviano, a qual prevê uso de } \mathbf{c} \text { para grafar } / \mathbf{k w} / \mathrm{e} \\
\mathbf{q} \text { somente para grafar som de /k/ antes de vogais /e/ ou /i/. A inadequação em } \\
\text { questão é idêntica à outra já analisada anteriormente, ocorrida no texto de outro } \\
\text { aluno boliviano, o qual, apesar de ter sido alfabetizado na escola brasileira, } \\
\text { apresentava interferência fossilizada da LM, devido à presença isolada do } \\
\text { vocábulo cuando em meio a vocábulos da língua portuguesa, inclusive } \\
\text { marcados por oralidade. Diferenciam-se, assim, as duas inadequações, pelo que } \\
\text { ocorre no entorno delas. A que temos ao lado aparece acompanhada do }\end{array}$} \\
\hline
\end{tabular}




\begin{tabular}{|c|c|}
\hline \multicolumn{2}{|c|}{$\begin{array}{l}\text { vocábulo hirman, evidenciando a homogeneidade do trecho no que diz respeito } \\
\text { à interferência do espanhol, o que revela estágio inicial de aquisição da língua } \\
\text { portuguesa, marcado pela presença não isolada de interferência da LM } \\
\text { espanhola. Trata-se, portanto, de equívoco fossilizável, mas ainda não } \\
\text { fossilizado. }\end{array}$} \\
\hline $\begin{array}{l}\text {... a minha hirman... (46) } \\
\text {...eu acho que quando agen brigar, u amigo } \\
\text { tem que separar a briga... (45) }\end{array}$ & $\begin{array}{l}\text { (sem adequações para o fenômeno) } \\
\text { (sem adequações para o fenômeno) }\end{array}$ \\
\hline \multicolumn{2}{|c|}{$\begin{array}{l}\text { Alterações gráficas nos vocábulos irmã e alguém, gerando os exemplos de } \\
\text { interlíngua hirman e agen. No primeiro caso, o acréscimo de } \mathbf{h} \text { justifica-se pela } \\
\text { interferência de hermana, vocábulo da LM do aluno. No entanto, percebe-se } \\
\text { que há movimento de aproximação ao registro do vocábulo em português, } \\
\text { certamente motivado pelo contato com a língua falada, pois o aluno substitui a } \\
\text { vogal inicial i por e, e elimina a vogal a final do vocábulo, deixando restar a } \\
\text { nasalização /ã/ que, embora esteja grafada de acordo com a regra do espanhol, } \\
\text { faz a grafia hirman ser homófona à de irmã. Assim, o equívoco do aluno é } \\
\text { mostra de que a aproximação ao registro em português está em processo e que, } \\
\text { certamente, ocorre pelo contraste que o aluno faz entre sua LM e a língua } \\
\text { portuguesa que escuta, eliminando o que é diferente, e substituindo-o pelo que } \\
\text { julga representar graficamente aquilo que ouve. O mesmo processo ocorre no } \\
\text { segundo exemplo agen, porém, ainda sem as substituições: o aluno eliminou da } \\
\text { grafia do espanhol alguien tudo o que, por contraste, não detecta no equivalente } \\
\text { alguém. Trata-se da consoante /l/, a qual não detecta auditivamente por ser ela } \\
\text { realizada como /w/ em posição final de sílaba; da semivogal /j/, a qual não } \\
\text { existe no vocábulo em português; e, no mesmo movimento, a vogal u do } \\
\text { dígrafo gu, a qual, por não ser detectada auditivamente, foi eliminada. Assim, o } \\
\text { que sobra é agen, estrutura que receberá os outros elementos à medida que o } \\
\text { aluno for adquirindo-os. As incorreções analisadas - casos típicos de interlíngua } \\
\text { - dizem muito sobre a forma como os alunos adquirem o português, a qual se } \\
\text { deu, nesses casos, pelo esforço em contrastar as palavras semelhantes do } \\
\text { espanhol com as do português. }\end{array}$} \\
\hline
\end{tabular}

\subsection{Considerações sobre os dados obtidos das análises linguísticas}

Nestas considerações são apresentados os elementos que marcam a produção escrita dos brasileiros e dos bolivianos. Fundamentaram as análises os conceitos de Ferreira Netto (2011) sobre descrição fonética e aparelho fonador; Aragão (2000) sobre ditongação e monotongação; Costa (2007) sobre vocalização); Lemos (2011) sobre alçamento vocálico; Souza (2009), Reis e Dias (2006) e Lopes e Callou (2004) sobre apagamento; Quednau (2000) sobre acento; Masip (1999) sobre morfossintaxe do espanhol; e Viaro (2004) sobre etmologia. 
Sobre a produção dos alunos nativos, foi possível observar que as inadequações estão relacionadas, principalmente, ao registro influenciado pela oralidade. São os casos de alçamento das vogais e e o (chatiado, muleques, vuadora); vocalização de $\mathbf{l}$ em final de sílaba (normau, acontecel); ditongação (fais, veiz); monotongação sobretudo de desinência verbal de pretérito perfeito do indicativo (ele começo, acerto, fico); e apagamento da desinência de infinitivo -r (brinca, ve, $\boldsymbol{d a}$ ). Inadequações relacionadas à complexidade do sistema fonético-fonológico da língua portuguesa foram as que envolveram o registro do fonema /s/, nas quais houve neutralização de sua representação (fis, isso, idiotisse, atraz, engrassada). Os casos referentes à ausência de acentuação (musicas, dificil, tambem, so, ja) podem ter sua causa na relação não estabelecida entre o acento prosódico e a lógica que rege o sistema de distribuição dos diacríticos em língua portuguesa.

A respeito das adequações, quando houve, indicaram que os erros poderiam não ser sistemáticos, como, por exemplo, no caso dos alçamentos, em que a vogal alçada graficamente atingiu apenas o interior do vocábulo (chatiado, muleques) e não o final (parte). Por outro lado, a ausência de adequações para alguns fenômenos indicou problemas relacionados ao sistema, como foram os casos de não acentuação e neutralização do registro do fonema /s/, para os quais houve reduzido ou desconsiderável número de adequações - o que configura área de maior atenção para o professor.

Algumas adequações gráficas observadas evidenciaram que os vocábulos de maior incidência no cotidiano escrito do aluno não apresentaram interferência da oralidade, mesmo havendo algum fenômeno oral que pudesse migrar para a escrita. São os casos de menino (sem alçamento da vogal e, embora o fenômeno ocorra na fala), estou (sem monotongação da terminação verbal) e você (corretamente acentuado). Esses exemplos demonstram que os vocábulos de maior incidência acabam construindo para o aluno uma "fotografia" que facilita a memorização. A leitura no cotidiano também conduz a esse efeito, diminuindo a influência da oralidade na modalidade escrita da língua. Assim, a julgar pelos equívocos observados, e pela homogeneidade de nível de linguagem no interior dos textos que apresentaram os equívocos, é possível deduzir que o cotidiano dos autores possui reduzidas oportunidades de contato com a língua escrita. Vale lembrar que a observação não se refere à totalidade das produções dos alunos brasileiros, mas somente aos que apresentaram equívocos, os quais foram numerados no corpo da análise e podem ser lidos na íntegra no Anexo 2. 
As produções dos alunos bolivianos, por sua vez, apresentam aspectos que variam conforme o tempo de escolarização em português. Quanto mais tempo na escola brasileira, mais raras são as transferências da LM, apresentando alternância de registro dentro do mesmo texto (com migo/comigo, ora/hora); e quanto mais recente é a escolarização em língua portuguesa, mais abundantes são os casos de interferência da LM, chegando a haver exemplos de interlíngua (hirman e agen) e inadequações sistemáticas, envolvendo registro de nasalização (ten, un, estan) e de timbre vocálico (não diferenciação entre e, conjunção, e é, verbo). Tais casos evidenciam as áreas fossilizáveis, e, por isso, de maior captação da atenção dos professores.

Houve, nas inadequações dos alunos bolivianos, semelhanças com as produções dos alunos brasileiros, revelando (1) incorporação de alguns traços da oralidade do português, como presença de alçamento de vogais e e o (disculpa, confiu), ditongação (mais, nois - no entanto, sem indicação de abertura de timbre); e (2) dificuldades com o sistema da língua, o que também afeta os nativos largamente, como a neutralização de registro de fonema /s/ (injustisa, adolecentes), e a ausência de acentuação (pessimo,ja).

Foi bastante comum observar pouca ou nenhuma adequação para as incorreções presentes nos textos dos alunos bolivianos, o que revela que os fenômenos analisados tratam-se, em grande parte, de erros sistemáticos. No entanto, esse aspecto não reduziu o nível de linguagem dos textos, já que os equívocos relacionam-se mais a interferências da LM ou a algumas incorporações de traços da oralidade do português. Assim, o nível de linguagem, sobretudo o vocabulário empregado pelos alunos bolivianos, revelou (apesar dos problemas apontados) textos com maior elaboração e especificidade.

Nas turmas mistas que congregam alunos brasileiros e bolivianos é possível que um quadro como o exposto se configure. Para complementá-lo, principalmente sobre questões que ultrapassam o domínio linguístico, realizou-se análise discursiva para apontar os elementos culturais das produções. É o que se vê no capítulo seguinte. 


\section{CAPÍTULO 4. ANÁLISE DO DISCURSO: O ETHOS COLETIVO}

Finalizada a análise dos aspectos fonético-fonológicos, partimos para a apreciação dos elementos culturais extraídos dos textos produzidos, os quais são necessários para o presente estudo por apresentarem informações sobre os brasileiros e sobre os bolivianos que podem auxiliar o professor a verificar e a compreender a visão de mundo e os valores de seus alunos. Conforme já visto no início do trabalho, optou-se, dentro da Análise do Discurso, pela identificação da imagem de si construída pelos enunciadores, a qual, conformando o ethos coletivo, reflete o que é valorizado ou desvalorizado nas culturas em questão.

Iniciamos pela identificação da imagem construída pelos enunciadores brasileiros, com o objetivo de contrastar seus valores e visão de mundo com os dos alunos bolivianos. Antes de tudo, é importante relembrar que o ethos é a imagem construída pelo enunciador para tratar de um tema específico (MAINGUENEAU, 2008), o qual, para esta pesquisa, é a relação entre amizade e violência, tema extraído da ilustração de uma camiseta (no quadro abaixo) e que motivou a escrita dos textos pelos alunos ${ }^{12}$.

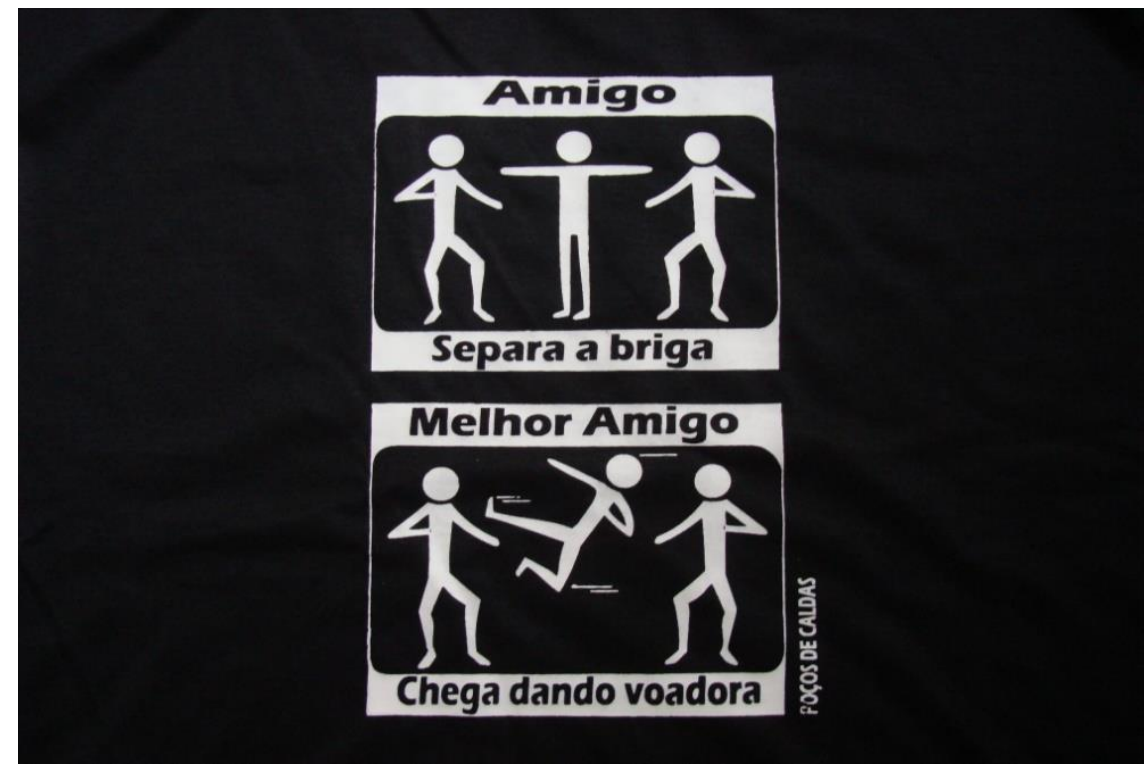

Imagem 1. Ilustração da camiseta utilizada como proposta de atividade escrita

\footnotetext{
${ }^{12} \mathrm{O}$ texto da proposta pode ser visto no APÊNDICE 2.
} 


\subsection{Os ethe identificados no discurso escrito dos alunos brasileiros}

Por meio da leitura dos 38 textos produzidos pelos alunos brasileiros, foi possível identificar a recorrência de quatro aspectos que auxiliam a construir o ethos coletivo:

1. o posicionamento conciliatório em relação às vozes que representam as tensões envolvidas no tema;

2. a consideração do amigo como um defensor ou salvador que se utiliza da violência para demonstrar amizade;

3. a naturalização da violência na esfera da amizade;

4. e o rechaço à violência nas relações, argumentado com palavras próprias ou com a reprodução do discurso dos adultos.

É o que se vê nos trechos extraídos dos textos, os quais se encontram na versão original, sem correção ortográfica ${ }^{13}$ :

Quadro 27 - O posicionamento conciliatório em relação às vozes presentes no tema

Eu acredito nisso e eu usaria uma blusa asim é eu não gosto disso mas só que já acontecel isso comigo (texto 22)

Não sou muito a favor de qualquer tipo de violência (...) Eu não sou nem contra e nem fazer ( a favor) do que essa imagem nos mostra (...) Mas é bem legal essa imagem, não por conta da violência e sim pelo valor que nós temos para um amigo (texto 19)

Esta camiseta tem um lado cômico, mas também é algo muito sério que acontece em muitos lugares (texto 9)

É coisa interesante e engraçada, mais muito violento (texto 13)

Eu acho bem engraçado o que está escrito nessa foto e concordo com isso, apesar de não gosta muito dos meus amigos se envolverem nas minhas brigas. (texto 21 )

(...) achei esse gesto meio violento (...) eu faria isso por um amigo (texto 33)

Sempre tem um palhaço que chega com brincadeiras de mal gosto, mais isto é uma modo de disse oi (...). Isso é muito normau no cotidiano (texto 10)

Eu acho na mesma hora certo e na mesma hora errado (texto 12)

Por um lado acho bom por uma pessoa está separando uma briga e por outro não porque não é justo um amigo chegar dando voadora (texto 2 )

\footnotetext{
${ }^{13}$ A versão integral dos textos encontra-se no ANEXO 2.
} 
O posicionamento conciliatório presente no discurso dos alunos brasileiros evidencia-se na escolha de argumentos que consideram, diante do tema, tanto a defesa quanto o rechaço à violência na esfera da amizade. Não se trata de argumentação contraditória, mas da consideração das vozes que representam as tensões do tema, como se, ao demonstrar atendê-las, o enunciador mostrasse ser menos importante posicionarse firmemente, e mais apropriado ponderar. Essa escolha evita conflitos e preserva o enunciador no sentido de deixá-lo livre para tomar das vozes aquilo que lhe é interessante, sem compromisso com um posicionamento definitivo ou com o aprofundamento da própria argumentação.

Assim, frente à camiseta que aprova, por meio do humor, a violência na esfera da amizade, há os argumentos que afirmam ser a camiseta "legal", "engraçada", ter um "lado cômico", o que significaria concordar com o seu conteúdo ou, em "eu usaria", defender o seu uso, trazendo para a construção da imagem do enunciador a inteligência e a leveza que o humor confere ao tema. No entanto, não é interessante ao enunciador comprometer-se com a aprovação da violência, desse modo, nos mesmos textos encontramos os relatos contra o ato violento. É o que se vê no texto 22 "Eu acredito nisso e eu usaria uma blusa assim" e "eu não gosto disso"; no texto 19 "é bem legal essa imagem" e "Não sou muito a favor de qualquer tipo de violência"; no texto 9 "Esta camiseta tem um lado cômico" e "mas também é algo muito sério que acontece em muitos lugares"; no texto 13 "É coisa interessante e engraçada" e "mais muito violento"; e no texto 21 "Eu acho bem engraçado o que está escrito nessa foto e concordo com isso" e "apesar de não gosta muito dos meus amigos se envolverem nas minhas brigas". Já no texto 33, a afirmação "achei esse gesto meio violento", apresenta desvalorização do conteúdo da camiseta, posicionando o enunciador contra a violência, para, na continuação "eu faria isso por um amigo" garantir para si a característica positiva do amigo defensor. O posicionamento conciliatório também se apresenta no texto 10, em que o enunciador qualifica como "palhaço" aquele que "chega com brincadeiras de mal gosto", mas considerando também que (a voadora) é uma forma de a pessoa cumprimentar os colegas, de "disse (dizer) oi".

Os trechos dos textos 12 e 2 trazem explícita, pela escolha lexical, a preocupação em conciliar posicionamentos. Há neles, respectivamente, as expressões "na mesma hora certo e na mesma hora errado" e "Por um lado (...) por outro" funcionando como conectores de alternância, conferindo linguisticamente ponderação, atenção a mais de uma voz de dentro do tema. 
Posicionar-se de forma a conciliar mais de uma voz do tema revela sobre os enunciadores a valorização dada ao não conflito, característica que encontra eco no homem brasileiro formado nas estruturas patriarcais de obediência e não discordância que se desenvolveram desde o período colonial no Brasil, as quais extrapolam a ordem familiar e atingem a pública. Ajudam-nos a compreender a origem dessa característica na sociedade brasileira as observações de Sérgio Buarque de Holanda (1975) sobre o que definiu como "homem cordial", sendo este distante do que a nomenclatura pode sugerir de cortesia, simpatia ou educação, mas, tomado etimologicamente, considerando-se o "cordial" como relativo a "coração", ou seja, àquele que transporta para as esferas públicas as relações permeadas da subjetividade afetiva própria do ambiente familiar. As esferas públicas, às quais é imprescindível o debate objetivo, tornam-se mediadas pelas emoções das esferas íntimas, diminuindo o compromisso com o que se discute, mas valorizando a manutenção das relações interpessoais. Nas palavras do autor:

Só pela transgressão da ordem doméstica e familiar é que nasce o Estado e que o simples indivíduo se faz cidadão, contribuinte, eleitor, elegível, recrutável e responsável, ante as leis da Cidade. Há nesse fato um triunfo do geral sobre o particular, do intelectual sobre o material [...]. A ordem familiar, em sua forma pura, é abolida por uma transcendência. (HOLANDA, 1975, p.36)

Ao não transgredir a ordem doméstica, os enunciadores, sem que atribuam para si as características de ponderação e conciliação, revelam possuí-las pelo modo como enunciam, agregando à sua imagem o ethos conciliador. No entanto, há um desdobramento desse ethos verificável nos discursos. Ponderar e conciliar as vozes do tema significam, antes de tudo, não prejudicar, mas, além disso, não se prejudicar. $\mathrm{O}$ discurso dos alunos brasileiros constrói a imagem dos enunciadores não como compromissados com essas vozes, mas consigo mesmos, na medida em que tomam delas aquilo que lhes assegura uma posição de não conflito.

Apartando-nos do ponto de vista histórico da construção do ethos conciliador presente na sociedade brasileira, e aproximando-nos dos nossos dias, pode-se observar esse compromisso consigo mesmo como sendo característico das sociedades pósmodernas, em que a efemeridade das transformações sociais, culturais, econômicas, políticas e técnico-científicas, nas palavras de Brunelli (2008) 
criam um mundo essencialmente instável, produzindo efeitos na vida psíquica dos indivíduos, uma vez que a efemeridade e a descartabilidade - de coisas e pessoas - que caracterizam esse mundo, tornam precários e transitórios os sistemas de valores públicos e pessoais. (2008, p. 138)

Desse modo, a rápida transformação da sociedade dificulta desde a fixação de valores até a interpretação do sistema pelos sujeitos que dela participam, gerando a crença no material, no palpável, naquilo que se vê, como o corpo e os objetos de consumo. Assim, movendo-se sobre valores transitórios, o ser dessas sociedades hesita em engajar-se ou posicionar-se, sobretudo diante de questões de caráter público. O comprometimento fica atrelado àquilo que considera mais palpável e menos transitório diante dos seus olhos: ele mesmo. Portanto, além do ethos conciliador, o engajamento consigo mesmo está presente na imagem que os enunciadores brasileiros constroem de si pela maneira como enunciam, imagens estas tributárias das relações históricas patriarcais e do caráter individualista das sociedades pós-modernas em que a brasileira está inscrita.

Quadro 28 - Amigo visto como um defensor

(...) isso é uma atitude de amizade (30)

(...) acredito nisso porque melhores amigos te defendem (texto 3 )

Um melhor amigo sempre te defenderá com unhas e dentes (texto 15)

(...) pra quem é amigo de verdade faz isso pelo outro (texto 37)

(...) melhor amigo fais tudo com você se mete emcrenca vai com voce pra onde for (texto 28)

Então ele chegou (o melhor amigo) (deu) um monte de soco neles é nós saimos correndo e depois eu o agradesi. (texto 7)

Ele queria me bater mas eu tinha um melhor amigo que não deixou ele me bater, depois a gente foi ficando melhor amigo (texto12)

Nunca se sabe se ele faria o mesmo por você (texto 11)

Nunca separei uma briga com uma voadora so se for muitos contra um amigo ou irmão (texto 13)

Nos trechos acima, o ato violento como demonstração de afeto não se dá entre os sujeitos da relação, mas dirigido a um elemento que ameaça um dos amigos. $\mathrm{O}$ ato agressivo, então, se torna uma "atitude de amizade", fazendo do sujeito violento o defensor, aquele que se coloca em situação de perigo para preservar o outro. É o que se verifica em "melhores amigos te defendem", "te defenderá com unhas e dentes", "amigo de verdade faz isso pelo outro" e "se mete emcrenca". 
Observa-se nos discursos a valorização da imagem de salvador que o amigo deve possuir, aspecto responsável pelo fortalecimento da amizade, presente em "depois a gente foi ficando melhor amigo". Note-se que o ethos construído pelos enunciadores não ocupa a posição do salvador, mas a do protegido, aquele que espera ser cuidado, posição moldada de acordo às sociedades erguidas sobre valores cristãos e patriarcais.

Tais valores se complementam e estão na formação da sociedade brasileira desde o período colonial, visto que o patriarcado monocultor e escravocrata, para defender a posse do poder sobre pessoas e grandes extensões territoriais, se apoiava e justificava a manutenção de sua existência na submissão e na domesticação da Igreja. Nas palavras de Gilberto Freyre:

No Brasil, a catedral ou a igreja mais poderosa que o próprio rei seria substituída pela casa-grande de engenho. Nossa formação social, tanto quanto a portuguesa, fez-se pela solidariedade de ideal ou de fé religiosa, que nos supriu a lassidão de nexo político ou de mística ou consciência de raça. Mas a igreja que age na formação brasileira, articulando-a, não é a catedral com o seu bispo a que se vão queixar os desenganados da injustiça secular; nem a igreja isolada e só, ou de mosteiro ou abadia, onde se vão acoitar criminosos e prover-se de pão e restos de comidas mendigos e desamparados. É a capela de engenho. Não chega a haver clericalismo no Brasil. Esboçou-se o dos padres da Companhia (de Jesus) para esvair-se logo, vencido pelo oligarquismo e pelo nepotismo dos grandes senhores de terras e escravos. (FREYRE, 1986, p. 224)

Essa subordinação da Igreja ao poder dos senhores de engenho aproxima o patriarcado brasileiro da figura individual do salvador cristão, fazendo deste senhor de engenho o responsável pela população, à qual cabia obedecer e esperar pelo auxílio. Pode estar neste aspecto da formação social brasileira a origem da valorização do ethos de protegido ou cuidado, daquele que deposita no outro a responsabilidade da sua defesa. E, mesmo quando, no discurso dos enunciadores brasileiros, há a construção do ethos como salvador, isso se dá como comportamento defendido em situações extremas de "muitos contra um amigo ou irmão" ou na defesa da reciprocidade do ato, como em "Nunca se sabe se ele faria o mesmo por você", em que, mesmo assim, ainda há a preocupação em garantir a proteção vinda do outro.

Assim, vê-se não somente na maneira de enunciar, mas na própria enunciação, a construção do ethos de seres à espera de proteção e cuidado. Possivelmente, sua proporção nos textos relaciona-se com a medida desse contingente na sociedade 
brasileira, reprodutora ainda do modelo patriarcal, reformulada pela democracia, mas ainda tolerante com os poderes locais não mais abertamente hereditários, mas estrategicamente longevos. Poderes estes sentidos mais fortemente pelas populações periféricas das quais os enunciadores são parte e acabam por tolerar e reproduzir, no discurso, seu lugar não protagonista.

Quadro 29 - A naturalização da violência

Isso é muito normau no cotidiano (texto 10)

Eu acho bem engraçado o que está escrito nessa foto e concordo com isso (...) Melhor amigo chega mesmo dando uma voadora, quando ver seu melhor amigo brigando, isso faz parte das melhores amizades (texto 21)

(...) eu já vi umas pessoas dando voadora do seu melhor amigo, mais foi assim de brincadeira (texto 26)

Eu acho uma coisa normal, até engrassada (...) e brigo muito com meus amigos (texto 31)

(...) achei esse gesto meio violento mais amigo é amigo né? (texto 33)

(...) não acho que isso é errado É um amigo querendo ajudar o outro. (texto 36)

Eu usaria essa camiseta sim é de humor muito legal (texto 38)

(...) isso na camiseta acontece sempre em escolas. (texto 29)

(...) meu outro amigo deu uma voadora no menino, que acerto o pescosso e o menino fico em coma por 3 meses (texto 17)

(...) quando se é melhor amigo o descontrole é mais difícil de conter, pois você não quer ver uma pessoa querida por você se machucando (texto 25)

Tomar um ato violento como "normau no cotidiano" ou fazendo "parte das melhores amizades" pode significar tê-lo já naturalizado. As passagens "brigo muito com meus amigos" e "já vi muitas pessoas dando voadora no seu melhor amigo" reiteram essa naturalização, mesmo considerando aí o fato de ter havido interpretação equivocada da ilustração da camiseta - na qual o ato violento não se dá no interior das amizades, mas dirigido a um elemento de fora que ameaça um dos amigos. $\mathrm{O}$ aspecto lúdico de "foi assim de brincadeira" e a indulgência com o ato mesmo após uma ressalva, "achei esse gesto meio violento mais amigo é amigo né?", mais uma vez, são enunciações que evidenciam o conviver, sem problematização, com o ato violento.

Essa naturalização da violência, quer seja como "parte das melhores amizades" ou "dando uma voadora quando ver seu melhor amigo brigando", não constrói sobre os 
enunciadores o ethos violento, visto que há nos trechos apenas um exemplo em que há certa exaltação ou exagero desse tipo de ato, "meu outro amigo deu uma voadora no menino, que acerto o pescosso e o menino fico em coma por 3 meses". No entanto, a violência não parte do enunciador, a não ser que ele esteja ocultando-se sob a forma de "meu outro amigo". O trecho "brigo muito com meus amigos" é o único em que, declaradamente, o enunciador é o agente, porém, não há definição quanto ao significado de "brigo", estando a ação bastante imprecisa - se física ou verbal - o que indica a pouca importância dada ao ato em si.

A afirmação de que os enunciados não constroem o ethos violento se mantém mesmo considerando que os discursos se deram em situação avaliativa, na qual o enunciador geralmente evita os posicionamentos que o prejudicam, como mostrar-se violento, característica rechaçada no ambiente escolar. A afirmação, portanto, baseia-se na concepção de Maingueneau (2008) sobre o ethos, de que a sua identificação se dá mais pela maneira como se enuncia e menos pelo enunciado propriamente. Desse modo, quando o enunciador deixa ver que a violência está no cotidiano das amizades, que é considerada "brincadeira" ou que "é um amigo querendo ajudar o outro", o ato violento ganha peso simbólico, passando a significar descontração lúdica ou prova de amizade. A naturalização da violência é resultado deste processo. E o enunciador, então, constrói sobre si o ethos relacionado a essa naturalização, o que, como visto, o distancia do ethos violento, mas o aproxima da indiferença à penetração da violência no âmbito das relações. Nascimento e Cordeiro (2011), em artigo sobre a violência no namoro entre jovens, citam Bourdieu (1999) ${ }^{14}$ para mostrar o processo em que o ato violento se torna naturalizado:

Tomando como base os estudos de Bourdieu (1999, p. 47), entendemos a violência simbólica como a naturalização da relação de dominação, que é incorporada pelo dominado, não sendo assim possível nem mesmo de ser pensada. Trata-se de uma violência exercida sobre os corpos e que resulta da "incorporação de classificações, assim naturalizadas, de que seu ser social é produto". (NASCIMENTO; CORDEIRO, 2011, s/p.)

Assim, é possível concluir que os enunciadores, ao considerarem o ato agressivo como "normau no cotidiano", apresentam-se como produto de um meio violento. Nascimento e Cordeiro definem violência como "um dado cultural e societário, com uma grande variação em suas formas de manifestação, em função do contexto

\footnotetext{
${ }^{14}$ Bourdieu, P. A dominação masculina. Rio de Janeiro: Bertrand, 1999.
} 
sociocultural em que ocorre, e da diversidade e complexidade dos valores que assume, em cada um destes contextos particulares". A partir disso, identificam três tipos de manifestação da violência recorrentes na sociedade brasileira que colaboram para a sua naturalização e que podem estar presentes no cotidiano dos enunciadores brasileiros: a violência contra a mulher, a violência na mídia e a violência decorrente da pobreza. Tais manifestações concorrem no dia-a-dia de toda a população brasileira, a qual pode ocupar posição de espectador, agente ou vítima. Os enunciadores brasileiros, alunos da escola, pertencem às camadas populares e médias da população, e estão, por isso, mais expostos aos seus efeitos. É o que se procura mostrar na sequência.

Sobre o que atinge as mulheres, as autoras lembram que, no Brasil, somente na década de 1970 o argumento da violência como "legítima defesa da honra" foi questionado legalmente e que apenas "a partir da lutas feministas no início dos anos 1980, a violência contra a mulher é entendida como um problema social, que demanda serviços e políticas públicas". Existem mecanismos de defesa e de denúncia como a Delegacia da Mulher e a Lei Maria da Penha, no entanto a população feminina mais pobre ainda não se beneficia largamente deles por, muitas vezes, estarem dependentes economicamente do companheiro agressor ou compartilharem filhos e bens. As autoras citam Saffioti (2004) ${ }^{15}$ para relacionar este aspecto a uma questão estrutural de desigualdade de gênero na sociedade brasileira:

As sociedades regidas por uma ordem patriarcal de gênero alimentam estruturalmente desigualdades de gênero e poder, toleram e, até certo ponto, incentivam a violência contra a mulher. (SAFFIOTI, 2004 apud NASCIMENTO; CORDEIRO, 2011, s/p.)

No cotidiano de jovens pertencentes às camadas populares e médias da população, a violência contra a mulher - seja doméstica ou conjugal, física, verbal ou psicológica é bastante presente na mídia, com destaque para a televisiva. Este veículo, a televisão, para as camadas mais pobres, apresenta-se como uma das principais opções de lazer disponível, alternando-se com a mídia digital, internet, para as camadas médias. Tais mídias, sobre o conteúdo em questão, veiculam uma a reverberação da outra. As autoras apontam dois casos de assassinato de meninas pelos seus ex-namorados, os quais foram amplamente televisionados em todo o Brasil:

\footnotetext{
${ }^{15}$ Saffioti, H. I. B. Gênero, patriarcado, violência (Coleção Brasil Urgente). São Paulo: Fundação Perseu Abramo, 2004.
} 
(...) como forma de ilustrar essa ampla exploração da mídia à violência entre namorados, destacamos, em 2008, o (caso) de Eloá, que foi morta a tiros pelo ex-namorado, após 100 horas de cativeiro (...), e, mais recentemente, em 2009, o caso de Mariana Sanches, assassinada a tiros pelo ex-namorado em uma academia (...). A esses casos somam-se outros com desfechos tão trágicos quanto os de Mariana e Eloá (...) (NASCIMENTO; CORDEIRO, 2011, s/p.)

Assim como os casos de violência contra a mulher, outros crimes são igualmente espetacularizados, sendo veiculados como narrativas, com personagens, enredo e sequência em capítulos, assemelhando-se, muitas vezes, às telenovelas. E, tal qual no gênero dramático, os seres parecem não pertencer à realidade, estando seus sucessos ou inssucessos no âmbito da ficção. Tratando-se de violência, esta passa a ser entretenimento, o que a banaliza e naturaliza.

No entanto, compartilhando com as autoras a decisão de não adotar "uma visão maquiavélica ou determinista da mídia" - mas de considerá-la como "inserida num jogo de relação de forças, competições e disputa por posição hegemônica" - a presente pesquisa toma a espetacularização midiática como uma das manifestações da violência na sociedade brasileira, recorrente e reiterante no cotidiano dos enunciadores brasileiros. Nas palavras das autoras "a mídia é um importante fator de socialização que influencia na construção da violência e nas subjetividades dos jovens no mundo contemporâneo".

A terceira forma de manifestação da violência, a decorrente da pobreza, não é possível relacionar diretamente aos enunciadores, assim como não o foi ao tratarmos da violência relativa à mulher e da relativa à mídia. Os motivos são a limitação do corpus, o qual não permite conclusões objetivas relacionadas ao contexto social dos enunciadores. Abordam-se aqui a pobreza e a violência pela sua quase indissociabilidade na sociedade brasileira, o que, para parte do ambiente social da escola estudada, se confirmou em conversas informais com o diretor, a coordenadora e os professores. Nessas conversas, havia dois dados recorrentes: primeiramente, os alunos sobre os quais se falava e que representavam os maiores desafios relativos a comportamento, para os mestres e a direção, somavam uma porcentagem pequena no contingente, cerca de 4 ou 5 por cento (número a que se chega pelas expressões "um grupinho" ou "uns dois ou três por sala", utilizadas pelos professores, sendo 40 a quantidade média de alunos em sala de aula). O outro dado recorrente era a relação estabelecida entre comportamento e família, esta caracterizada como desestruturada ou ausente nos casos em que os alunos apresentavam comportamento violento, baixa 
frequência injustificada, desinteresse independente da disciplina ministrada, problema de relacionamento com os professores, baixa autoestima, isolamento, ou seja, os maiores desafios ali plantados. A desestruturação familiar, de acordo com os profissionais da escola, era relacionada à ausência dos pais, ou de um deles, por abandono ou divórcio; bem como envolvimento com algum tipo de crime, este variando desde uso de drogas ou tráfico, até assaltos, o que resultava em longos períodos de detenção ou desaparecimento como forma de fuga à lei. Nesses casos, os filhos também tinham a rotina escolar alterada, já que acabavam precisando mudar-se para a casa de algum parente ou abrigo - quando havia interferência do conselho tutelar - ou ainda ausentar-se da escola para cuidar dos irmãos. Desse modo, a desestruturação familiar coloca os jovens em situação de vulnerabilidade social. Abramovay (2002), em estudo sobre violência e juventude, descreve vulnerabilidade social como:

(...) o resultado negativo da relação entre a disponibilidade dos recursos materiais ou simbólicos dos atores, sejam eles indivíduos ou grupos, e o acesso à estrutura de oportunidades sociais, econômicas, culturais que provêm do Estado, do mercado e da sociedade. Esse resultado se traduz em debilidades ou desvantagens para o desempenho e mobilidade social dos atores. (...) A situação de vulnerabilidade aliada às turbulentas condições socioeconômicas de muitos países latino-americanos ocasiona uma grande tensão entre os jovens que agrava diretamente os processos de integração social e, em algumas situações, fomenta o aumento da violência e da criminalidade. (ABRAMOVAY, 2002, p. 13, grifos nossos)

Esclarece-se que o quadro descrito, de acordo com os profissionais da escola, relaciona-se concretamente às famílias de uma pequena parcela dos estudantes, cerca de 4 a 5 por cento, como já foi mencionado. Faz parte, portanto, do cotidiano doméstico dessa porcentagem de alunos, mas não se ignora que também esteja presente indiretamente no dia-a-dia dos demais colegas, conformando o contato próximo com a violência, fazendo das suas manifestações um elemento tolerado ou naturalizado.

Por fim, de todos os enunciados, houve um em que o enunciador, embora demonstrasse aceitar a violência nas relações, apresentou reflexão, problematizou o caso. Trata-se do trecho "quando se é melhor amigo o descontrole é mais difícil de conter, pois você não quer ver uma pessoa querida por você se machucando". A violência não figura como naturalizada, mas como opção extrema justificável pelo igual nível de amizade, pois vale para "quando se é melhor amigo". 
Contudo, houve nas enunciações o rechaço à violência, com expressões que revelavam decisão própria do enunciador em posicionar-se contra o ato violento, e também expressões que ecoavam a fala dos adultos e seus ensinamentos sobre a convivência pacífica. É o que se vê a seguir.

Quadro 30 - O rechaço à violência nas relações

(...) è bem muita locura (texto 29)

Amigo de verdade quer ver o melhor do parceiro, não atiçar mais a briga (texto 9)

Dois amigos meus brigaram e não foi legal (texto 18)

(...) eu não usaria uma camiseta dessa (texto 23)

Sou totalmente contra essa imagem (texto 9)

$\mathrm{Eu}$ acho ridiculo isso não acho que isso e um ato de amizade sim de vandalismo (texto 24)

Éstas atitudes não são certas (texto 11)

Melhor amigo separa e orienta (texto 11)

(...) só está gerando mais violência (texto 8)

(...) violência não leva a nada (texto 17 )

(...) violência só gera violência (texto 23)

O discurso dos brasileiros constrói também o ethos pacífico e intolerante à violência no âmbito das relações. Interessante foi constatar dois tipos de enunciação a esse respeito: o primeiro, por meio de expressões próprias que demonstravam autoria, construiu um ethos pacífico autêntico, fruto, talvez de reflexão ou experiência vivida. São exemplos disso os trechos "è bem muita locura", "Amigo de verdade quer ver o melhor do parceiro, não atiçar mais a briga", "Dois amigos meus brigaram e não foi legal", "eu não usaria uma camiseta dessa" e "Eu acho ridiculo isso não acho que isso e um ato de amizade sim de vandalismo". O segundo tipo de enunciação reverbera a fala dos adultos, os ensinamentos do bom conviver, a ideia do certo e do errado "Éstas atitudes não são certas", e o bom proceder "Melhor amigo separa e orienta". Esse segundo tipo também ecoa as campanhas antiviolência: "só está gerando mais violência", "violência não leva a nada" e "violência só gera violência".

Os dois tipos de enunciação apontam para o rechaço à violência, evidenciando, de um lado, enunciadores independentes no posicionamento, os quais se utilizam da experiência vivida para argumentar; e, de outro lado, enunciadores atrelados ao discurso 
que lhes é reafirmado no cotidiano, seja o dos adultos ou o institucional, o que aponta para a presença da família, da escola, bem como da mídia, na orientação dos jovens.

\subsubsection{O ethos coletivo brasileiro}

Conclui-se esta seção verificando-se que as enunciações dos alunos brasileiros constroem um ethos coletivo em que predominam o posicionamento conciliador e descompromissado; a visão de que o amigo deve ser um salvador ou cuidador; a naturalização da violência nas relações, resultante da exposição dos jovens a ambientes ou fontes de repertórios violentos; e o rechaço à violência nas relações, alcançado por meio de argumentação em que se destacam a autoria e independência dos jovens, bem como a presença do discurso dos adultos, revelando a participação da família, escola e demais instituições atuantes no cotidiano dos alunos brasileiros, e que participam da sua formação.

A seguir, realiza-se similar análise do discurso dos alunos bolivianos.

\subsection{Os ethe identificados no discurso escrito dos alunos bolivianos}

O exame dos 8 textos produzidos pelos alunos bolivianos destacou as seguintes características que auxiliam a construir o ethos coletivo:

1. o posicionamento único na argumentação, sem preocupação em conciliar as vozes do tema;

2. a visão de que o amigo é um salvador ou cuidador;

3. a aceitação da violência nas relações como forma de reparar injustiças;

4. e o rechaço à violência nas relações, consequência de experiência vivida, reflexão ou absorção do discurso dos adultos.

É o que se vê na sequência: 
Quadro 31 - Posicionamento único, sem preocupação em conciliar as vozes do tema

Bom acho péssimo (...) não gosto de me meter em confusão (...) Seria bom se todos agissem no primeiro quadro (...) se não tivesse essa de briga (texto 2 )

(...) quando um é o melhor amigo ele ja o defende o melhor amigo. Eu ja defendi meu melhor amigo (...) acho uma injustiça que dois adolecentes batam em um pré adolecente. (texto 1)

Eu acho que quando agen brigar u amigo tem que separar a briga é não chegar e da um voadora pra u outro deve separar e pedir disculpa para cada um. (texto 7)

É uma situação violenta de forma mal adequada (...) não gosto de comentar sobre isso. (texto 4)

Os trechos acima foram selecionados porque contêm o posicionamento declarado dos alunos frente ao tema proposto. As passagens "acho péssimo", "seria bom se todos agissem no primeiro quadro", "é uma situação violenta" e "não gosto de comentar" revelam enunciadores que se colocam contra a violência no âmbito das relações. Tal posicionamento se mantém, e a argumentação segue coerente, variando somente o projeto de cada um, se mais subjetivo - com verbos na primeira pessoa, privilegiando as experiências pessoais; ou mais objetivo, com verbos na terceira pessoa, pronomes indefinidos como "todos" e "agen (alguém)", afastando-se do relato pessoal, e apresentando a argumentação geral para as situações em que há violência. O mesmo ocorre no texto 1 , em que há a aceitação da violência como defesa ou reparação de "uma injustiça", estando a argumentação voltada a atender somente a essa voz.

Percebe-se, assim, que há envolvimento com o posicionamento declarado, estando ausente a preocupação em conciliar as vozes do tema. Tais vozes seriam, por exemplo, a que cativa a argumentação pelo humor que a estampa contém, a que convida a vestir a camiseta desconsiderando o seu rechaço declarado à violência, ou a voz que minimiza e naturaliza as ações violentas. Esse envolvimento com o tema proposto pode estar relacionado à posição ocupada pelos alunos bolivianos nas situações de violência que ocorrem no ambiente escolar. De acordo com declarações dos alunos bolivianos e de seus pais, bem como do diretor da escola, há diversas situações envolvendo atos violentos em que os alunos bolivianos são o alvo. Esses alunos apanham, são roubados ou forçados a roubar, além disso, são chantageados e ameaçados para que não denunciem as ocorrências, as quais têm como cenário o interior da escola, a saída ou as áreas próximas (esse silêncio imposto aparece em um dos trechos dos textos: "não gosto 
de comentar sobre isso"). O diretor conta o caso de dois irmãos bolivianos que, no final de 2013, tiveram os aparelhos celulares roubados por alunos da escola durante a saída, mas que, ameaçados, não denunciaram o ocorrido. A direção soube do caso somente porque a mãe dos alunos notou que os filhos não brincavam com os celulares depois do jantar, como era costume. Questionando seus filhos, a mãe descobriu que haviam sido roubados na saída da escola. Depois que ela levou o caso à direção, outros semelhantes foram descobertos, com a ajuda dos familiares ou dos próprios alunos vítimas, os quais se encorajaram a fazer os relatos por sentirem-se mais seguros dentro de um grupo de denunciantes. A direção tomou providências, realizando reuniões semanais com todos os alunos imigrantes da escola, as quais tinham como pauta as necessidades desses alunos, o que, no início, estava relacionado aos casos de violência. $\mathrm{O}$ grupo de alunos imigrantes contava com maioria boliviana, mas havia também dois peruanos, uma argentina, uma síria, um paraguaio e uma angolana. Inicialmente, houve conversas para sensibilizar os alunos sobre a necessidade de levar os casos de violência ao conhecimento dos pais e da direção. Não havia, nesse momento, alunos brasileiros nas reuniões, já que o grupo era exclusivo de imigrantes. Não houve pressão da direção para que se incluíssem brasileiros, mesmo havendo a consciência de que isso poderia gerar um gueto de estrangeiros a partir daquele grupo. No entanto, a inclusão dos brasileiros se deu de forma natural. Os alunos imigrantes decidiram formar um grupo que recepcionaria e protegeria todos os estrangeiros que chegassem à escola, grupo este constituído por integrantes igualmente estrangeiros. Com o passar das reuniões, sem pressão da direção ou coordenação, alguns alunos brasileiros foram chamados para integrar o grupo de recepção, já que se chegou à conclusão de que eles também representavam a escola. Além disso, alguns alunos brasileiros, amigos dos integrantes, começaram a se interessar pelas reuniões semanais dos alunos imigrantes, passando a fazer parte delas. Atualmente, depois de 8 meses de início das reuniões - iniciadas em março de 2014 - as pautas não mais necessitam estar relacionadas aos casos de violência. Embora eles ainda existam, não são mais silenciados. Hoje, nessas reuniões, há apresentações e discussões sobre elementos culturais do país dos imigrantes ali presentes, o que tem a finalidade de sensibilizar o grupo quanto à diversidade da escola. Como desdobramento dos encontros e das questões ali apresentadas, houve a criação e execução do projeto "Expedição à Bolívia", o qual levou, em outubro de 2014, oito 
alunos, entre bolivianos e brasileiros, para conhecer a cidade de La Paz, objetivando aprofundar a troca e a sensibilização intercultural iniciadas nas reuniões ${ }^{16}$.

Pelo relato feito, é possível observar de qual ponto de vista o aluno boliviano olha ao tratar de tema relacionado à violência. Um ponto de vista menos espectador e mais envolvido. Daí pode vir o comprometimento com o posicionamento e com a argumentação, o que transparece no uso de expressões próprias e autorais, fruto da experiência vivida, como "Eu ja defendi meu melhor amigo", "seria bom se não tivesse essa de briga" ou "acho uma injustiça que dois adolecentes batam em um pré adolecente". Assim, o ethos que o enunciador boliviano constrói é o de comprometido com a argumentação, devido à experiência de ter estado, ou de estar, em posição desfavorável nos conflitos que envolvem violência. Este comprometimento pode ser percebido também no direcionamento que é dado à argumentação, na qual se incluem elementos que extrapolam a subjetividade e apontam para a preocupação com o outro: "acho uma injustiça que dois adolecentes batam em um pré adolecente", "Seria bom se todos agissem no primeiro quadro (...) se não tivesse essa de briga" e "Eu acho que quando agen brigar $\mathrm{u}$ amigo tem que separar a briga é não chegar e da um voadora pra $\mathrm{u}$ outro deve separar e pedir disculpa para cada um". A consideração do outro é própria de sociedades organizadas sobre preceitos de coletividade, como é a boliviana andina - de onde se originam os alunos - a qual é menos inserida no contexto pós-moderno individualista descrito anteriormente, quando se tratou do ethos conciliador identificado no discurso dos alunos brasileiros. O sentido comunitário pode ser percebido na organização familiar boliviana, a qual avança para além do núcleo próximo e aceita a participação de membros da família estendida para a tomada de decisões. Quiroga et al (2007) definem a família boliviana urbana andina, e explicam seu caráter coletivo:

La família boliviana (...) conforma lo que se conoce como "familia extendida", es decir, papá y/o mamá, hijos e hijas que viven bajo el mismo techo, y que en algunos casos reciben el apoyo económico, vivienda, apoyo en el cuidado de los hijos, etc., de otros familiares, como abuelos, tíos, parientes políticos, etc. Además del apoyo material y simbólico, es muy común la participación del conglomerado familiar - por ejemplo, en la toma de decisiones para la solución de problemas de forma activa y cotidiana, e inclusive para la toma de decisiones importantes - . Existen, además, otros agentes que influyen en las decisiones familiares, como los padrinos, que en ciertos estratos sociales incluso se convierten en referentes morales. (2007, p.10)

\footnotetext{
${ }^{16} \mathrm{O}$ relatório sobre a "Expedição à Bolívia" encontra-se no APÊNDICE 3.
} 
A participação da "familia extendida" no cotidiano das famílias nucleares não se dá apenas como forma de remediar a fragilidade econômica existente para grande parte da sociedade boliviana andina. Trata-se de uma metodologia própria traduzida pela palavra aimará qamaña, que significa conviver, dialogar e dividir. Essa metodologia é bastante presente nas áreas rurais, em que há a participação dos membros da comunidade em todas as questões administrativas. Essa participação inicia-se quando uma mulher e um homem adultos formam um casal, prerrogativa para que constituam uma complementaridade, estando aptos a harmonizarem-se nas questões administrativas. Esse casal começa atuando nas decisões relativas à educação, participando do dia-a-dia da escola, verificando atuação dos professores, merendas, material escolar. Após um período determinado nesta atuação, passam a responsabilidade para outro casal recém formado, e iniciam atividades em outra área, e assim sucessivamente, até o casal passar pelos diversos setores da comunidade, como os relacionados à moradia, agricultura, comércio dos produtos, saúde, entre outros. Passando por todos os setores de forma rotativa, os membros envolvem-se concretamente com a administração pública, aprendendo, atuando e dividindo o conhecimento pela metodologia da qamaña, em que se convive com para compreender. O último estágio da administração é participar do conselho de anciãos da comunidade, no qual estarão pessoas que acumularam os saberes relativos aos diversos setores administrativos públicos, constituindo-se como as maiores autoridades locais.

Esse caráter tradicional do universo rural indígena é o que está na base do que se nota de comunitário nas famílias urbanas andinas. A "familia extendida" é uma forma de multiplicar auxílios, experiências e cuidados com os membros. Essa característica é responsável pela consideração do outro, identificada no discurso dos alunos bolivianos. Nota-se que, nas enunciações, a consideração do outro se dá a partir da experiência vivida "acho uma injustiça que dois adolecentes batam em um pré adolecente", o que demonstra envolvimento com o tema; e se dá também pela reprodução de ensinamentos, como em "deve separar e pedir disculpa para cada um", trecho que traz a fala dos adultos, flagrante pelo uso do verbo dever e da construção "pedir disculpa para cada um", esta muito recorrente no discurso dos familiares ou dos adultos da escola nas ocasiões em que há brigas entre as crianças.

Assim, o posicionamento fixo na argumentação e a consideração do outro constroem, a respeito do enunciador boliviano, o ethos de comprometimento com o 
tema e com a comunidade, o que é tributário de uma sociedade de caráter coletivo e menos inserida no contexto pós-moderno. Esse afastamento em relação às sociedades pós-modernas reduz a rapidez com que as crenças e valores compartilhados se modificam, contribuindo para o comprometimento com esses valores e crenças, assim como com a argumentação que os sustenta. Além disso, as sociedades de caráter coletivo têm os valores relativos ao individualismo - como busca pela liderança, ascensão individual, isolamento e consumo - reduzidos, algo que se nota nas enunciações dos estudantes bolivianos por meio de um movimento que contraria essa tendência, movimento este marcado pela consideração do outro. Tal aspecto não se deve somente às características da sociedade boliviana de coletividade e menor individualismo. Vale lembrar que a consideração do outro é valor chave das colônias de apoio que imigrantes formam nas sociedades-destino. Assim, quando o estudante boliviano distancia-se da sua subjetividade e considera o próximo - o seu colega - ele está se inserindo no sistema de apoio, posicionando-se como parte da rede constituída no ambiente escolar, área dentro de sua abrangência. E, por fim, a atuação como colônia de apoio, além de preservar o outro, como em "ja defendi meu melhor amigo" ou "acho uma injustiça que dois adolecentes batam em um pré adolecente", também busca a autopreservação, presente em "não gosto de me meter em confusão" e "não gosto de comentar sobre isso", enunciações que manifestam um tipo de comportamento precavido bastante comum em imigrantes, o de não se envolver em situações vistas como comprometedoras ou ameaçadoras de si ou do grupo.

As características observadas diferenciam as enunciações dos alunos bolivianos das dos alunos brasileiros. Seguimos com as análises para, ao final, estabelecer os elementos que constituem o ethos coletivo depreensível das enunciações dos alunos bolivianos.

Quadro 32 - Amigo visto como um defensor

(...) o meu melhor amigo veio corendo e deu uma voadora no menino que queria me dar um soco (...) (texto 3$)$

Eu já defendi meu melhor amigo ele estava apanhando de dois adolecentes e quando eu chegei eu o defendi por que eu acho uma injustiça que dois adolecentes batam em um pré adolecente. (texto 1)

Eu ya fez isso cuando a minha hirman tava brigando com sua amiga Eu fui la e bati en ela (texto 8) 
Amigo que e com longa data, de Amizade sim chega chegando ajúda sempre que puder. Eu já vivi esa emoção mais não e boa por que são dois contra um ou seja eu fiz errado i deveria ter separado por que eu não vou ficar para sempre com ele é ele tem de a comprende a ser consiente. (texto 5)

(...) algumas pessoas dissem que são minhas amigas mas quando há briga não me defende (texto 6)

Nas enunciações dos estudantes bolivianos a respeito da figura do amigo, assim como no discurso dos alunos brasileiros, este aparece como um defensor, um salvador. Dos oito textos produzidos, os cinco selecionados comprovam essa afirmação. No entanto, há duas diferenças entre o discurso dos alunos: a primeira refere-se ao tipo de relação estabelecida entre o enunciador e a sua enunciação; a segunda refere-se a quem ocupa a posição de salvador.

No discurso dos alunos brasileiros, há predomínio da relação abstrata entre o enunciador e a enunciação, a qual se trata de situação que envolve um amigo hipotético: "acredito nisso porque melhores amigos te defendem", "Um melhor amigo sempre te defenderá com unhas e dentes", "pra quem é amigo de verdade faz isso pelo outro" e "melhor amigo fais tudo com você se mete emcrenca vai com voce pra onde for". Já no discurso dos alunos bolivianos, há relação concreta entre enunciador e enunciação, pois os autores tratam de fatos em que há experiência vivida, e não hipotética: "o meu melhor amigo veio corendo e deu uma voadora no menino que queria me dar um soco", "Eu já defendi meu melhor amigo ele estava apanhando de dois adolecentes", "Eu ya fez isso cuando a minha hirman tava brigando com sua amiga", "eu não vou ficar para sempre com ele é ele tem de a comprende a ser consiente" e "algumas pessoas dissem que são minhas amigas mas quando há briga não me defende". Essa primeira diferença pode ser creditada à posição que, geralmente, o aluno boliviano ocupa nas situações em que há violência na escola, como já foi mencionado na análise feita anteriormente. $\mathrm{O}$ fato de ser alvo de violência na escola o coloca como detentor dessa experiência, estabelecendo, portanto, relação concreta com ela.

A segunda diferença está relacionada a quem ocupa a posição de defensor. No discurso dos alunos brasileiros há o predomínio de enunciações em que o amigo de quem se fala é o defensor. Por sua vez, no discurso dos bolivianos, há variação: em dois dos trechos selecionados o amigo de quem se fala é o defensor; e, nos outros três trechos, o defensor é o amigo que conta o fato, ou seja, o enunciador. Essa característica, além de retomar a ideia de experiência vivida, e não hipotética, dos 
alunos bolivianos como alvo nos casos de violência ocorridos na escola - e por isso, nessa experiência, o amigo aparece ora como quem salva, ora como quem é salvo, indicando a variação típica dos papéis ocupados nesses acontecimentos - tal variação a respeito de quem ocupa a posição de defensor ainda aponta para a atuação dos alunos bolivianos como membros de colônia de apoio de imigrantes, também já mencionada na análise anterior, colônia esta em que os integrantes alternam sua posição na rede de apoio.

Dessa forma, é possível observar e compreender as diferenças entre a visão que se tem do amigo no discurso dos alunos brasileiros e no dos bolivianos. Contudo, a semelhança em considerá-lo, em ambos os casos, um defensor salvador, pode ser encontrada no processo histórico pelo qual passou a sociedade boliviana na sua formação, processo este parecido com o brasileiro no que diz respeito ao patriarcalismo do período colonial, representado pelo colonizador detentor dos recursos e do controle, constituindo-se como elemento central do sistema, e gerando dependência daqueles em sua órbita.

A figura patriarcal, tanto no Brasil como na Bolívia, representou a construção da imagem de concentração de poder sobre muito território e muitas pessoas nas mãos de poucos homens, sendo estes os possuidores dos recursos e da mão de obra, e também os que definiam as leis de controle. Fuentes (2010) nos explica como foi o processo de apropriação do território que hoje comporta a Bolívia, bem como dos indígenas nativos, e aí podemos verificar a construção do patriarcado, como também observar os elementos que particularizam o processo boliviano:

La política de dominación europea, implantada en América desde el principio mismo de la conquista, se expandió sistemáticamente hacia la expoliación de tierras comunarias de los indígenas. (...) El Estado colonial utilizó la segregación y diferenciación étnica para extraer el excedente a la población nativa. Las funciones económicas de cada estamento impusieron diferentes deberes y mandatos entre los habitantes de las colonias. Los españoles gozaban de los derechos y los indígenas sufrían las obligaciones. (FUENTES, 2010, p. 65)

A respeito da forma de exploração das terras dos nativos, os processos brasileiro e boliviano se diferenciam. Ambas as sociedades conviveram com três séculos de colonização em que o protagonismo nas decisões envolvendo permissão e proibição era privilégio de um grupo pequeno, mas dominante. São os três primeiros séculos que conformaram a nova ordem americana, bem como as suas sociedades, cujo modelo 
patriarcal tornou-se recorrente nas porções latinas - o que inclui Brasil e Bolívia. No caso brasileiro, houve apropriação das terras, escravização e/ou assassinato de indígenas. No entanto, o processo boliviano apresenta uma particularidade: o colonizador espanhol não se apropriou das terras indígenas sistematicamente, senão da sua produção, sistema tributário que manteve economicamente o Estado durante todo o período colonial, estendendo-se até a independência.

Toledo (o Estado colonial) segregó oficialmente alrededor de 161.000 indígenas en comunidades y poblados que se sujetaron al control estatal. La mayor parte de los pueblos reales de indios estaba localizada en el Altiplano (área andina). A cada pueblo indígena se le otorgó derechos de usufructo de un territorio específico. A cambio, la comunidad nativa en conjunto debía cumplir con una cuota tributaria. (FUENTES, 2010, p. 67)

Assim, a organização social das comunidades nativas foi mantida durante o processo colonial, estando a dominação relacionada ao processo produtivo para assegurar o pagamento de tributos - o que se dava em produtos da comunidade, em dinheiro ou em trabalhadores para as minas, sobretudo as de prata. Essa preservação da organização social comunitária foi obtida por resistência indígena e pela noção, por parte do colonizador, de que as comunidades poderiam, a seu modo, gerar produção e pagamento de impostos, sem precisar haver a interferência do Estado colonial em determinar uma nova organização - algo que lhe seria custoso.

Findo o período colonial, a partir da república, em 1825, e de inúmeras e violentas rebeliões indígenas, o tributo foi suspenso oficialmente. Em seu lugar, e como forma de extrair ainda dos indígenas a sustentação econômica, iniciou-se a expropriação das terras. O Estado republicano passou a exigir dos indígenas que comprovassem, por meio de documentação, a posse das suas terras. Em sua maioria analfabetos - devido à proibição de acesso à educação formal em espanhol, a língua do universo oficial poucos indígenas conseguiram comprovar legalmente a posse das terras:

Requisitos escandalosos, el corto plazo para reivindicar títulos y el canon a pagar, tenían por mira deliberada evitar que los aborígenes, mantenidos al margen de la información y cortos en dinero, ejercieran la opción. En estas condiciones, pocos indígenas pudieron hacer valer su derecho o estuvieron dispuestos a pagar por aquello que siempre habían poseído. Así fue como se vendieron numerosas estancias a los favoritos del régimen. (FUENTES, 2010, p. 74-75) 
Os citados favoritos do regime eram os descendentes dos colonizadores - os criollos - ou os estrangeiros ligados à exploração de minérios, sobretudo a prata. Nesse novo sistema, os indígenas tinham a quantidade de terras reduzida ou deveriam abandoná-las. Sem terras, a opção restante era trabalhar para os novos donos, estes ainda poucos e dominantes nas mesmas grandes áreas, agora chamadas latifúndios, os quais se estenderam por todo o Altiplano boliviano. Somente no departamento de La Paz - área de onde vem a maior parte dos imigrantes bolivianos residentes no Brasil, e por consequência os alunos participantes desta pesquisa - foram 109 as comunidades que perderam suas terras ancestrais, entre 1866 e 1869.

Atualmente, o Estado Plurinacional - assim denominado por incluir em sua representatividade as diversas etnias que formam a sociedade boliviana - procura, por meio de leis, restabelecer as terras ancestrais aos povos indígenas. No entanto, trata-se de ação bastante recente, a qual ainda não conforma um novo hábito de dominação territorial que substitua os mais de quatro séculos de exercício patriarcal de poder. Trata-se de período longo, durante o qual a existência de uma figura central em um território extenso regulava a vida da população, estabelecendo com ela uma relação de dependência. Esta dependência poderia envolver a proibição, gerando o medo, a revolta, a obediência, o inconformismo; ou poderia envolver a permissão, criando o controle e a manipulação dos comportamentos, a passividade, a dissimulação. Esses elementos marcam as sociedades de modelo patriarcal, nas quais os cidadãos temem o pai, mas também esperam o que vem dele. Essas características aproximam as sociedades brasileira e boliviana. No entanto, o fato de a organização social das comunidades indígenas ser mantida, durante os períodos colonial e republicano, preservou o caráter comunitário da sociedade boliviana andina, conectando-a como continuadora dos hábitos ancestrais de participação e vida coletiva. Assim, o que se observa nas enunciações dos alunos bolivianos sobre o amigo como defensor ou salvador - e que se diferencia das enunciações dos alunos brasileiros - está muito relacionado à participação efetiva nos acontecimentos narrados, à consideração do outro e à disposição em ocupar a posição de defensor. São ações ou atitudes próprias das colônias de apoio de imigrantes, mas também tributárias de uma sociedade original baseada na coletividade, característica mantida, como visto, mesmo durante a ocupação colonial.

Assim, a partir das enunciações sobre o amigo, o ethos construído é o de protegido ou cuidado, próprio das sociedades constituídas sob modelo patriarcal. Porém, 
devido aos enunciadores pertencerem também à sociedade de caráter comunitário e a serem parte de colônia de apoio de imigrantes, constrói-se o ethos de defensor.

Os mesmos elementos relacionados à sociedade comunitária e à colônia de apoio de imigrantes constituem ponto de partida para analisar as enunciações a seguir. Tratase da aceitação da violência nas relações como forma de reparar injustiça.

Quadro 33 - Aceitação da violência como forma de reparar injustiça

(...) ele disse que ia brigar com migo (...) mas ele era covarde e cuando ele tava perdendo mandou um de seus amigos me segurar (...) o meu melhor amigo veio corendo e deu uma voadora no menino que queria me dar um soco (...) (texto 3 )

Eu já defendi meu melhor amigo ele estava apanhando de dois adolecentes e quando eu chegei eu o defendi por que eu acho uma injustiça que dois adolecentes batam em um pré adolecente. (texto 1)

Eu ya fez isso cuando a minha hirman tava brigando com sua amiga Eu fui la e bate em ela (texto 8)

Dos oito textos produzidos, três contêm enunciações que endossam a violência nas relações como forma de intervenção em situação de injustiça. Comprovam claramente a afirmação os trechos "ele era covarde e cuando ele tava perdendo mandou um de seus amigos me segurar (...) o meu melhor amigo veio corendo e deu uma voadora no menino que queria me dar um soco" e "Eu já defendi meu melhor amigo ele estava apanhando de dois adolecentes". Não tão claro, mas presumível, é o trecho "Eu ya fez isso cuando a minha hirman tava brigando com sua amiga Eu fui la e bati em ela", em que o laço sanguíneo entre a agredida e o defensor é o fator que justifica a violência contra quem agride. Nas enunciações, a violência é vista como defesa "eu chegei eu o defendi" que aplica e se explica como forma de reparar uma injustiça "por que eu acho uma injustiça que dois adolecentes batam em um pré adolecente". Novamente, a situação de imigrante constituinte de grupo minoritário insere os alunos bolivianos em redes de proteção, constituídas consciente ou inconscientemente, mas com o fim de preservar os membros. O caráter comunitário da sociedade de origem, como se viu na análise anterior, também atua como força nas redes de proteção. Contudo, sobre a violência sendo enunciada como forma de corrigir ou reparar um ato visto como desvalorizado, como é o caso das injustiças, pode haver relação com o papel corretivo que certos tipos de violência possuem na sociedade boliviana andina, o que os 
faz tolerados. Para esta pesquisa, serão apresentados dois exemplos: os casos de justiça obtida por meio de violência em locais onde o Estado não atua; e os castigos corporais em ambiente escolar, tolerados e até incentivados pelos pais como forma de corrigir comportamentos inadequados.

Os casos de justiça obtida por meio de violência, quando ocorrem, se dão em áreas distantes ou não alcançadas pelo poder público, como zonas rurais ou periferias das grandes cidades. Os delitos e os comportamentos irregulares são julgados pela população de acordo ao ato cometido: estupradores e assassinos geralmente têm como sentença linchamento e morte; ladrões têm partes do corpo amputadas, normalmente as relacionadas ao crime, ou ainda são assassinados. Um exemplo é a cidade de El Alto, antigo bairro da periferia da cidade de La Paz alçado a município, composto por residências e pequenos comércios, além de ser o espaço para uma das maiores feiras populares ao ar livre do mundo. Ao andar por essa cidade, é comum ver nos postes da área central um boneco em tamanho natural humano, pendurado pelo pescoço como se estivesse enforcado, carregando uma placa no peito que adverte para o destino que podem ter os assaltantes e ladrões. Em uma cidade que concentra a economia no comércio popular, os roubos não podem constituir epidemia, o que prejudicaria ainda mais os rendimentos, além de afastar os clientes da área. O poder público, embora esteja localizado espacialmente a $15 \mathrm{~km}$ dali, na cidade de La Paz, não atua a contento na cidade, permitido ou tolerando esta forma de justiça, que se justifica e é vista como corretiva.

A outra forma de violência existente é a que envolve os castigos corporais em ambiente escolar, objetivando corrigir algum comportamento irregular. Trata-se de uma prática atualmente combatida nas instituições educacionais bolivianas, mas que ainda resiste como hábito ritual da justiça nas áreas rurais andinas. Gutierrez e Fernández (2011) explicam o que é conhecido como "chicotazo" e como atua na educação:

Recordemos que en la justicia comunitaria el chicotazo forma parte del ejercicio sancionatorio, pero se trata de un tipo de violencia ritual, socialmente controlada y culturalmente constituida, que no admite excesos ni se impone de modo indiscriminado. (GUTIERREZ e FERNÁNDEZ, 2011, p. 11)

Tal ritual relaciona-se à autoridade que o professor representa na escola e também a como é visto pela família dos estudantes dentro da concepção comunitária, na qual os elementos da sociedade participam do público e do privado. Na escola em que se deu o 
trabalho de campo para a presente pesquisa, as professoras contam de algumas mães bolivianas que procuram por elas para dizer-lhes que têm autorização para castigar os seus filhos caso não se comportem, valendo, para isso, os castigos corporais. Trata-se não só de reverberação da educação recebida na Bolívia - esta atualmente combatida mas também de uma maneira de incluir o professor brasileiro como parte da comunidade que admite o público como continuação do privado (la familia extendida), na medida em que este público atua para educar e corrigir.

São exemplos de formas toleradas de violência pela sociedade boliviana, justificáveis pelo seu valor de condução e correção dos membros. Essas práticas existentes na Bolívia acompanham os imigrantes e permanecem como reguladoras das ações das gerações posteriores. Assim, na enunciação dos alunos bolivianos sobre a violência nas relações, há a justificação do ato como sendo ele pertencente ao processo que resulta em obtenção de justiça para o agredido e correção do agressor. O ethos construído será, na falta de uma expressão menos descritiva, o de tolerante com a violência pelo seu caráter condutor.

\subsubsection{O ethos coletivo boliviano}

Conclui-se esta seção verificando-se que as enunciações dos alunos bolivianos constroem um ethos coletivo em que predominam o posicionamento inflexível e compromissado com a argumentação, fruto, certamente, da relação concreta construída com o tema violência - de que muitos alunos são ou foram alvo - e do caráter comunitário da cultura andina do qual os alunos são herdeiros e que favorece o engajamento nos temas que os cercam; a visão de que o amigo deve ser um salvador ou defensor, mas, diferentemente do discurso dos alunos brasileiros, esse defensor era o próprio enunciador, e não uma outra pessoa numa situação hipotética - o que salienta a posição de membro de colônia de apoio de imigrantes em que os estudantes se colocam; e a tolerância com a violência apenas quando ela se justifica por produzir justiça ou condução do comportamento, ao contrário, é rechaçada do ambiente íntimo das relações. 


\section{CONSIDERAÇÕES FINAIS}

Nestas considerações finais, retoma-se a pergunta da pesquisa:

Quais são as características linguísticas e culturais que diferenciam ou aproximam alunos bolivianos e brasileiros em uma sala de aula mista?

A partir das análises realizadas foi possível constatar que os alunos brasileiros e os bolivianos atuam, linguística e culturalmente, ora de maneira distinta, ora medida, de maneira similar.

Linguisticamente, a elaboração de uma gramática mínima da produção escrita mostrouse forma eficaz de seleção e análise das necessidades dos alunos, estando, ao final, assim configurada:

Quadro 34 - Gramática mínima da produção escrita dos alunos

\begin{tabular}{|c|c|}
\hline Alunos brasileiros & Alunos bolivianos \\
\hline $\begin{array}{l}\text { Realizam, por transferência de elementos da } \\
\text { oralidade: } \\
\text { - Apagamento de -r de infinitivo } \\
\text { (brigar) e de }-\mathbf{n}-\text { de desinência de } \\
\text { gerúndio (tomando) } \\
\text { - Ditongação (acréscimo de semivogal } \\
\text {-i (veiz e mais - conjunção) } \\
\text { Monotongação (eliminação } \\
\text { semivogal -u da desinência verbal de } \\
\text { pretérito perfeito (ele brigou, ele } \\
\text { brincou) } \\
\text { Alçamento vocálico de -e para -i } \\
\text { (disculpa) e de -o para -u (muleques) } \\
\text { Troca de -l por -u e de -u por -l } \\
\text { (normau, envouver) }\end{array}$ & $\begin{array}{l}\text { Realizam, por transferência de elementos da } \\
\text { oralidade do português (como os nativos) } \\
\text { - Apagamento de -r de infinitivo (dar) } \\
\text { - Ditongação (acréscimo de semivogal } \\
\text {-i (nois, mais - conjunção) } \\
\text { - Monotongação (apagamento de } \\
\text { semivogal -i em bestera) } \\
\text { Alçamento vocálico de -e para -i } \\
\text { (disculpa, i - conjunção) e de -o para } \\
\text { - u (confiu, u - artigo) }\end{array}$ \\
\hline $\begin{array}{l}\text { Realizam, por dificuldades com o sistema } \\
\text { linguístico: } \\
\text { - Neutralização do registro do fonema } \\
\text { /s/ (asim, ceparou, discusão) } \\
\text { - Não acentuação (musicas, violencia, } \\
\text { tambem) }\end{array}$ & $\begin{array}{l}\text { Realizam, por dificuldades com o sistema } \\
\text { linguístico: } \\
\text { - Neutralização do registro do fonema } \\
\text { /s/ (injustisa, adolecentes, esperiencia, } \\
\text { esa, consiente) } \\
\text { - Não acentuação (pessimo, ja, la) }\end{array}$ \\
\hline
\end{tabular}




\begin{tabular}{|c|c|}
\hline & $\begin{array}{l}\text { Realizam, por transferência de elementos da } \\
\text { língua materna espanhola }\end{array}$ \\
\hline & $\begin{array}{l}\text { - Indiferenciação de timbre da vogal -e } \\
\text { (vé, e -verbo-, é -conjunção) } \\
\text { - Indiferenciação entre /z/ e/s/ (disser - } \\
\text { infinitivo) } \\
\text { - Troca de -q por -c (cuando) } \\
\text { - Nasalização registrada em LM (ten, } \\
\text { - estan, en, un) } \\
\text { Registro em interlíngua (hirman, } \\
\text { agen) }\end{array}$ \\
\hline
\end{tabular}

A identificação das diferenças e semelhanças orienta as escolhas docentes sobre o tipo de ensino de língua de que irá lançar mão - se português como Língua Materna ou como Segunda Língua - para intervenções precisas sobre inadequações sistemáticas, fossilizações ou áreas fossilizáveis da produção de seus alunos. Tal atuação por parte dos professores atesta que a formação docente sob o discurso monolíngue não é suficiente para ensinar língua portuguesa em salas de aula configuradas como as turmas analisadas. Nos casos observados, de alunos saindo do ensino fundamental e avançando para o médio, a elaboração da gramática mínima e o consequente trabalho orientado para as necessidades específicas podem evitar que os alunos passem para a próxima etapa da escolarização com deficiências de aquisição de elementos das séries elementares.

Estudos posteriores podem conter a elaboração de gramáticas mínimas considerando aspectos morfossintáticos ou semânticos do corpus analisado.

Culturalmente, a identificação da visão de mundo e dos valores presentes nas salas de aula mistas respalda e orienta a atuação do professor, no sentido de dar-lhe informações sobre o que seu aluno expressa e sobre aquilo que não expressa, o que resulta em ações precisas e também cuidadosas por parte dos professores para promover a integração dos alunos, aproximar-se deles, interpretar ruídos e silêncios. No caso da escola Infante Dom Henrique, foi bastante comum, na conversa com as professoras, a associação de "silêncio, timidez e disciplina" aos alunos bolivianos, e da contrapartida aos alunos brasileiros. Desviando-nos de uma interpretação bipolar para apontar 
educados ou mal educados, comportados ou endiabrados, podemos recordar as análises culturais realizadas sobre o corpus, as quais relacionaram o comportamento dos alunos bolivianos também a sua condição de imigrante - situação na qual esses alunos demonstraram cautela, evitando conflitos, sendo o silêncio a forma de obter certa invisibilidade desejada. Os alunos brasileiros encontram-se em posição diferente, pois os nativos têm, geralmente, vivências culturais e formação de redes mais abrangentes, o que lhes proporciona atuação menos tensa em ambiente social. Além de considerar o aspecto da migração, as análises culturais relativas ao ethos coletivo relacionaram os alunos bolivianos a um tipo de sociedade constituída sob valores comunitários herança indígena andina - diferente dos alunos brasileiros, cuja sociedade está mais orientada para os valores individuais. Essa diferença pode explicar o que as professoras falavam sobre os alunos bolivianos serem silenciosos.

Sabendo que a quase totalidade dos bolivianos que imigram para o Brasil por trabalho são da área andina, esse silêncio não pode ser interpretado apenas como timidez. O silêncio inquieta e intriga aqueles que, não sendo de comunidades silenciosas, precisam conviver com pessoas que falam pouco. Essa inquietação que beira o desconforto foi objeto de reflexão do educador austríaco Ivan Illich no artigo $L a$ elocuencia del silencio, para quem o não-falar pode ensinar mais sobre as pessoas do que as suas palavras. Encontrou o nó da inquietação após conviver entre povos indígenas do México por alguns anos. "Se requiere más esfuerzo, tiempo y delicadeza para aprender el silencio de un pueblo que para aprender sus sonido" (ILLICH, 1974, s/p). Desse modo, o silêncio pode inquietar pelo fato de requerer decifração não obtida por meio de palavras. Considerando as contribuições de Dell Hymes (1972) sobre os componentes dos eventos comunicativos, tomemos o canal de comunicação. O ser silencioso faz poucos movimentos comunicativos de teste de canal, uso de funções fáticas, enfim, atos de fala que sirvam para marcar intenções de subjetividades não declaradas. Costumamos fazer uso desse tipo de comunicação para conhecer, analisar nosso interlocutor, encontrando meios de saber se somos queridos, aceitos ou se podemos aceitar o outro. No entanto, a detecção e o reconhecimento do outro podem se dar fora do canal comunicativo verbal, por meio de ações recíprocas, prestação de auxílios, realização de deveres para além dos individuais - características de sociedades comunitárias, em que muito das comunicações se dá menos pelo falar que pelo fazer. Pode estar aí a origem dessa característica apontada pelas professoras sobre os alunos bolivianos, estando a contrapartida atribuída aos alunos brasileiros - justificada, talvez, 
pelas tantas vezes que nós tomamos a palavra para marcar intenções e subjetividades que o nosso proceder ainda não expressou.

A identificação dos elementos culturais em congresso numa sala de aula mista não atua somente como contribuição ao trabalho do professor. Os alunos, quando descobrem a cultura do outro, apropriam-se de instrumentos para agir interculturalmente, o que favorece interação e dissolução de preconceitos construídos por desconhecimento. Sobre isso vale a pena citar a fala de uma aluna brasileira, membro da Expedição à Bolívia - realizada em outubro de 2014 pela Escola Infante Dom Henrique - ao contar a experiência de conhecer a cidade de La Paz: "Foi bom ter vindo (e tido) essa experiência. Vou levar em minhas memórias, gostei de todos os lugares que nós visitamos e a Bolivia que me falavam que era subdesenvolvida que tudo era antigo, não é a Bolivia que eu visitei" ${ }^{17}$.

Não sendo possível viajar ao país de cada estrangeiro membro de uma sala de aula mista, será o dia a dia o que fornecerá os elementos para a sensibilização intercultural dos presentes. Nesse sentido, por fim, narro um pequeno acontecimento cotidiano, o qual traduz a delicadeza dos atos que nos chegam para decifrar:

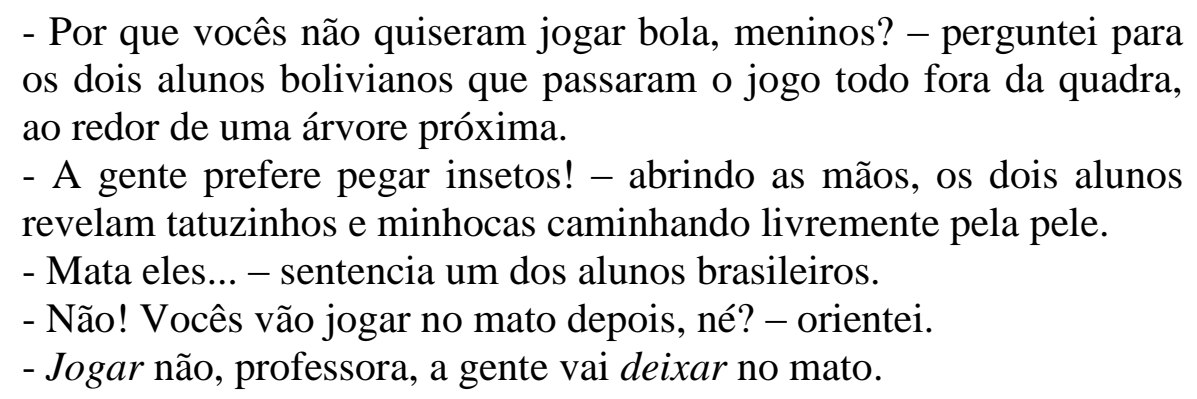
os dois alunos bolivianos que passaram o jogo todo fora da quadra, ao redor de uma árvore próxima.

- A gente prefere pegar insetos! - abrindo as mãos, os dois alunos revelam tatuzinhos e minhocas caminhando livremente pela pele.

- Mata eles... - sentencia um dos alunos brasileiros.

- Não! Vocês vão jogar no mato depois, né? - orientei.

- Jogar não, professora, a gente vai deixar no mato.

\footnotetext{
${ }^{17}$ Sobre a Expedição à Bolívia, ver APÊNDICE 3
} 


\section{REFERÊNCIAS}

AMOSSY, Ruth. Da noção retórica de ethos à análise do discurso. In: AMOSSY, Ruth (org.) Imagens de si no discurso. Paris: Editora Contexto, 2005.

ABRAMOVAY, Miriam. Juventude, violência e vulnerabilidade social na América Latina: desafios para políticas públicas. Brasília: UNESCO, BID, 2002. Disponível em: <http://unesdoc.unesco.org/images/0012/001271/127138por.pdf>. Acesso em 24/11/2014.

ARAGÃO, Maria do Socorro Silva. Ditongação X monotongação no falar de Fortaleza. Portal de Periódicos Científicos da UFPB Graphos. João Pessoa, p. 109120, 2000. Disponível em: <http://periodicos.ufpb.br/ojs/index.php/graphos/ article/viewFile/9349/5029>. Acesso em: 24/11/2014

BRUNELLI, Anna Flora. Confiança e otimismo: intersecções entre o ethos do discurso de autoajuda e o discurso da Amway. In: MOTTA, Ana Raquel. Ethos Discursivo. São Paulo: Editora Contexto, 2008.

CAMARGO, Valéria Sena. Traços fonético-fonológicos do Português para falantes do espanhol e do inglês: segmentos dificultadores para a aquisição do Português Brasileiro. Dissertação. (Mestrado em Filologia e Língua Portuguesa) - FFLCH, USP. São Paulo, 2009.

CORDER, S. P. The significance of leaners' errors. International Review of Applied Linguistics, v. 5, n. 4, p. 161-170, 1967.

COSTA, Cristine Ferreira. Análise variacionista da vocalização de /1/ em Porto Alegre. Revista Virtual de Estudos da Linguagem - ReVEL, v. 5, n. 9, ago. 2007. ISSN 1678-8931. Disponível em: 〈www.revel.inf.br〉.

DURÃO,Adja B. A. B. La interlengua. Madrid. Arco Libros. 2007.

EGGS, Ekkehard. Ethos aristotélico, convicção e pragmática moderna. In: AMOSSY, Ruth (org.) Imagens de si no discurso. Paris: Editora Contexto, 2005, p. 29-56

FERREIRA NETTO, Waldemasr. Introdução à fonologia da língua portuguesa. São Paulo: Paulistana, 2001.

FREYRE, Gilberto. Casa-grande e senzala. São Paulo: Editora Círculo do Livro, 1986.

FUENTES, Karen Cecília Claure. Escuelas Indigenales - Otra forma de resistencia comunaria. Cochabamba: Serrano Editores, 2010.

GARCÍA, Imaculada Solís. Observaciones críticas sobre los Estudios actuales acerca del error y la interlengua de los estudiantes de ELE. In: CONGRESO INTERNACIONAL DE ÁSELE, XVI, Atas... p. 616-627, 2005. Disponível em: <http://cvc.cervantes.es/ensenanza/biblioteca_ele/asele/pdf/16/16_0614.pdf.> Acesso em 09/07/2014. 
GORDONAVA, Alfonso Hinojosa. Migración Transnacional y sus Efectos en Bolivia. La Paz: PIEB, 2009.

GRASSO, Dick Ibarra. Las Lenguas Indígenas en Bolívia. La Paz: GUM, s/d.

GRONDIN, Marcelo N. Metodo de Aymara. La Paz: Ed. Los Amigos del Libro, 1999.

GUTIERREZ, Yamila; FERNÁNDEZ, Marcelo. Niñas (des)educadas: Entre la escuela rural y los saberes del ayllu. La Paz: PIEB, 2011.

HOLANDA, Sérgio Buarque de. Raízes do Brasil. 8 ed. São Paulo: Livraria José Olympio Editora, 1975.

HYMES, D. Models of the Interaction of Language and Social Life. In Directions in Sociolinguistics, p. 35-71, 1972.

ILLICH, Ivan. La Elocuencia del Silencio. IN Alternativas. Ed Joaquim Mortiz, Mexico, 1974.

JUNG, Neiva Maria. Eventos de letramento em uma escola multisseriada de uma comunidade rural bilíngue (alemão/português). Dissertação (Mestrado em Linguística Aplicada) - IEL/UNICAMP, Campinas, 1997.

LEMOS, Fernando Antônio Pereira. O alçamento das vogais médias pretônicas e postônicas médias. Revista Philologus, ano 19, no. 55, s/p, 2011. Disponível em: http://www.filologia.org.br/revista/artigo/9(26)12.htm>. Acesso em 26/07/2013.

LOPES, Célia Regina dos Santos; CALlOU, D. M. I. Contribuições da Sociolinguística para o ensino e a pesquisa: a questão da variação e mudança linguística. Revista do GELNE (UFC), v.5, p.63-74, 2004.

MAINGUENEAU, Dominique. A propósito do ethos. In: MOTTA, Ana Raquel. Ethos Discursivo. São Paulo: Editora Contexto, 2008. p. 11-29.

Ethos, cenografia, incorporação. In: AMOSSY, Ruth (org.) Imagens de si no discurso. Paris: Editora Contexto, 2005, p. 69-92.

MAGALHÃES, Giovanna Modé. Fronteiras do direito humano à educação: um estudo sobre os imigrantes bolivianos nas escolas públicas de São Paulo. Dissertação (Mestrado em Educação) FEUSP, São Paulo, 2010.

MASIP, Vicente. Gramática española para brasileños. Barcelona: Difusion, 1999.

MINISTÉRIO DA EDUCAÇÃO. Parâmetros Curriculares Nacionais - Língua Portuguesa / Ensino Fundamental. 2000.Disponível em <http://portal.mec.gov.br/seb/ arquivos/pdf/livro02.pdf > Acesso em 07/11/2014.

MINISTÉRIO DA EDUCAÇÃO. Parâmetros Curriculares Nacionais - Língua Portuguesal Ensino Médio. 2000. Disponível em < http://portal.mec.gov.br/seb/arquivos/pdf/14_24.pdf>, último acesso em 07/11/2014.

NASCIMENTO, Fernanda Sardelich; CORDEIRO, Rosineide de Lourdes Meira. Violência no namoro para jovens moradores de Recife. Psicol. Soc. v. 23, n. 3, 
set./dez. 2011. Disponível em <http://www.scielo.br/scielo.php? script=sci_arttext\&pid=S0102-71822011000300009 >. Acesso em: 24/11/2014.

QUEDNAU, Laura Rosane. $O$ acento do latim ao português arcaico. Tese. (Doutorado em Linguística) - PUCRS, Porto Alegre, 2000.

QUIROGA, Celia Ferrufino; QUIROGA, Magda Ferrufino; BUSTOS, Carlos Pereira. Los costos humanos de la emigración. La Paz: PIEB, 2007.

REIS, Mariléia; DIAS, Almerinda Bianca Batti. A vibrante final de infinitivo na fala de crianças em fase final de aquisição da linguagem: o efeito cumulativo de natureza fonomorfossintática sobre o fonema /r/. Revista Virtual de Estudos da Linguagem ReVEL. v. 4, n. 7, ago. 2006. ISSN 1678-8931 [www.revel.inf.br].

SCLIAR-CABRAL, Leonor. Princípios do sistema alfabético do português do Brasil. São Paulo: Editora Contexto, 2003.

SELINKER, L. Interlanguage. International Review Applied Linguistics, v. 10, n. 3, p. 209-231, 1972.

SOUZA, Socorro Cláudia Tavares de. Interferência da língua falada na escrita de crianças: processos de apagamento da oclusiva dental /d/ e da vibrante final $/ \mathrm{r} /$. DELTA, São Paulo, v. 25, n. 2, s/p, 2009.

TÉLLEZ, Teresa Marzana. Así enseñamos castellano a los quechuas. La Paz: Plural Editores, 2005.

TROUCHE, Lygia Maria Gonçalves. Leitura e interpretação: inferências socioculturais. Ensino da língua e da cultura no Brasil para estrangeiros. Niterói:Intertexto, 2005.

VARGAS, Manuel. Historia de Bolivia. La Paz: Correveidile Editorial, 2012.

VÁZQUEZ, Graciela. Hacia una valoración positiva del concepto de error. Antología de los Encuentros Internacionales del Español como Lengua Extranjera. Las Navas del Marqués (2010) 11. - ¿Errores? Sin falta! Madri: Edelsa, 1999.

VIARO, Mario Eduardo. Por trás das palavras: manual de etimologia do português. São Paulo: Globo, 2004.

VIEIRA, Maria Eta. Ensino e aprendizagem de PLE: os imigrantes bolivianos em São Paulo - uma aproximação sociocultural. Tese. (Doutorado em Linguagem me Educação) - FEUSP, São Paulo, 2009. 
ANEXO 1

Mapa com a distribuição das línguas e etnias pelo território boliviano

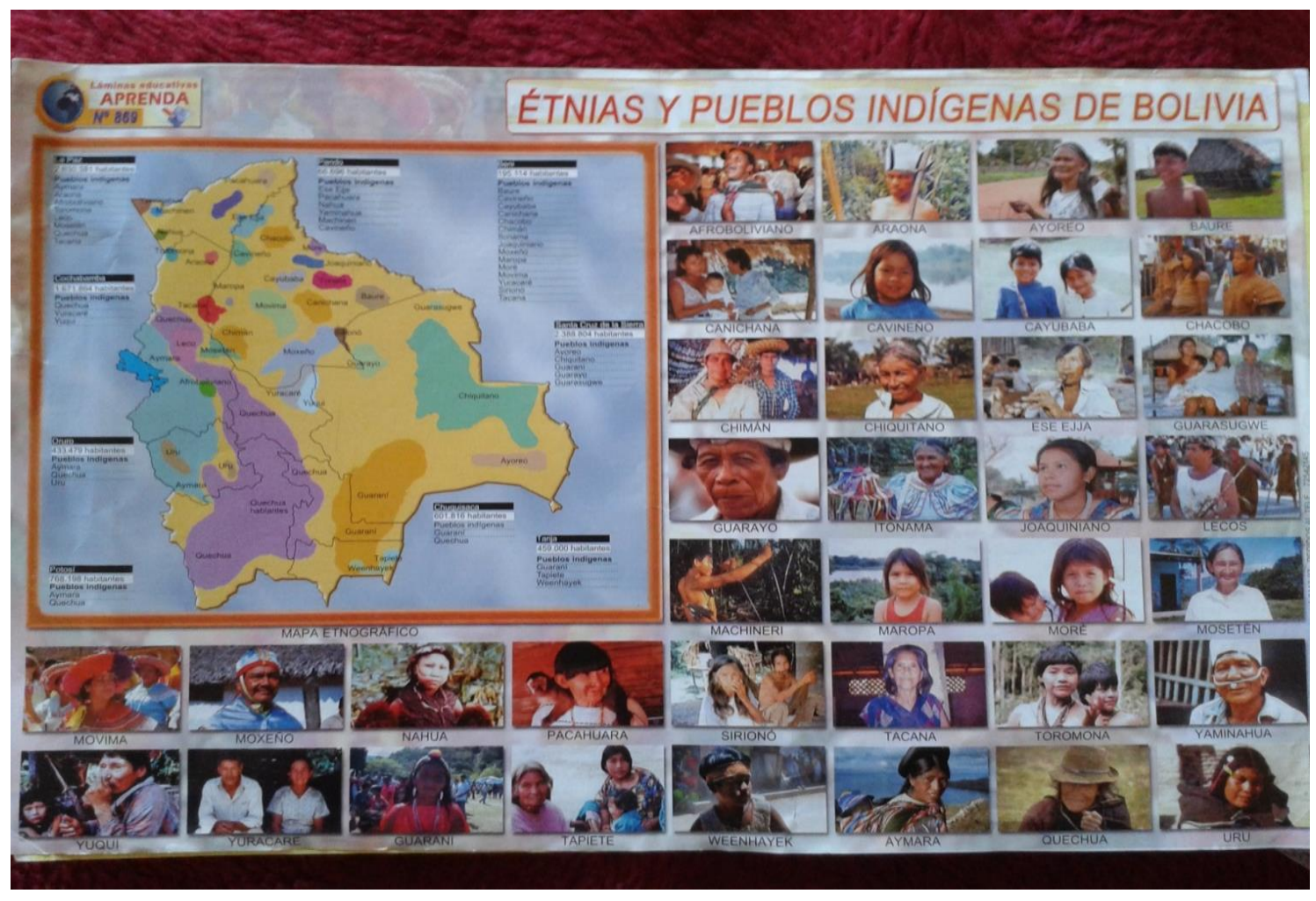




\section{ANEXO 2 \\ TRANSCRIÇÃO INTEGRAL DOS TEXTOS DO CORPUS}

\section{Textos dos alunos brasileiros}

\section{TEXTO 1}

Não usaria. Porque violencia gera violencia, a melhor maneira que tem é conversando. Já passei por essa situação, não defendi ninguem.

Eu não concordo com essa camiseta.

\section{TEXTO 2}

Bom o que eu to achando desta imagem nesta camiseta

Por um lado eu acho Bom Por uma pessoa está separando uma Briga e por outro não Porque não é justo um amigo chegar dando voadora.

\section{TEXTO 3}

Nunca aconteceu isso comigo, e eu tambem nunca vi isso acontecer com meus amigos, mas acredito nisso por que melhores amigos te defendem.

\section{TEXTO 4}

Sim, ja vir o meu amigo tava jogando bola e derrepente começo a brigar com o cara ai venho o meu outro amigo e eles começaram a bater no cara.

\section{TEXTO 5}

Sim ja vi; Tenho uma amiga que não posso disser o nome, quase se meteu em uma briga com outra garota por causa de um garoto e ela nem ao menos namora com ele uma outra colega a ex do garoto fez uma ameaça a minha amiga disse que "ela vai vê se ela se mete com ele", e minha colega chamada Aline chegou na sala da ex do garoto e já avisou que se mexeu com uma aluna da oitava mexeu com as três oitavas bem a garota já foi avisada agora o assunto parece que já morreu sei lá, mas a ex do garoto já se aquetou bom pelo que eu percebi.

\section{TEXTO 6}

teve uma vez que o meu colega patrique tava brigano e eu fui se para e a cabei tomano um soco, então nunca mais ceparo nenhuma briga

\section{TEXTO 7}

Eu tive um melhor amigo que ele ficou a $5^{\text {a }}$ serie e a $6^{a}$ serie tambem. Bom, ele era um bom amigo Forte ele gostava das mesmas musicas que eu uma veiz ele me ajudou numa briga feia sinco muleques vieram me bater então como eu sou esperto eu fiquei enrolando falando um monte de idiotise e aproveitei o momento e dei um soco na cara dele e corri mas um deles me deu uma rasteira e eu cai no chão então ele chegou um monte de soco neles é nós saimos correndo e depois eu agradesi.

\section{TEXTO 8}

Esta camisa quer dizer que, o melhor amigo do outro quer tentar resolver a briga de outra forma mas só está gerando mais violência. E o outro amigo quer levar na Base da Amizade mesmo. 


\section{TEXTO 9}

Esta camisa tem um lado cômico, mas também é algo muito sério que acontece em muitos lugares. Acredito que um amigo de verdade quer ver o melhor do parceiro, não atiçar mais a briga que o outro se meteu. Ou seja, sou totalmente contra essa imagem.

Nunca arrumei briga, então jamais aconteceu tal situação. E também nunca presenciei tal fato, mas sei que isso acontece demais.

TEXTO 10

Sim, Quando estou com amigos sempre tem um palhaço que chega com brincadeiras de mal gosto, mais isto é uma modo da pessoa de disse oi, mais tem gemte que não gosta de brinca.

Isso é muito normau no cotideano.

\section{TEXTO 11}

Na minha opnião éstas atitudes não são certas. Nunca passei por uma situacão dessas então fica complicado comentar.

Mas é assim por mais que a pessoa seja sua amiga você nunca deveria tomar uma atitude dessas, primeiro que só ira piorar as coisa, segundo que nunca se sabe se ele faria o mesmo por você, e depois os dois podem fazer as passes e acabarem ficando com raiva de você. Então o melhor amigo separa e orienta, e não chega dando voadora.

\section{TEXTO 12}

E acho na mesma hora certo e na mesma hora errado.

E errado brigar, mas tambem eu acho que e certo ajudar um amigo quando ele mais precisa de você.

Uma vez eu fui roubado, fui para minha casa falei para minha mãe, ela ficou preocupada, mas continuei vindo para a escola normalmente, um dia ele veio aqui na escola, ele estava na frente da escola, ele falou que queria converssa com migo, mas não acreditei nele é fui inginorante, ele queria me bater mas eu tinha um melhor amigo que não deixou ele me bater, depois agente foi ficando melhor amigo.

Nome dele e Anderson. Uns dos meus melhores amigos.

\section{TEXTO 13}

É uma coisa interesante e engraçada, mais muito violento.

Sim, eu já separei muitas briga, brigas de irmão contra inimigo, amigo vs amigo, inimigo contra inimigo, separei até briga de cachorro mas nunca separei uma briga com uma voadora so se for muitos contra um amigo ou irmão

\section{TEXTO 14}

Está camiseta significa; Que se uma pessoa for melhor amiga da outra já chega dando voadora sem saber o que aconteceu. e eu nunca vi isso em nenhum lugar.

\section{TEXTO 15}

Bem, já vi está imagem no fecebook, achei legal e ao mesmo tempo engraçada. Não me indentifiquei muito, pelo fato de eu nem minhas amigas se envouverem em brigas, discussões e etc.

Mas esse mês mesmo houve uma pequena confusão, uma garota estava com ciumes porque minha amiga estva com o ex-namorado desta garota, Chegou até a surgir boatos sobre ameaças desta garota e minhas amigas queriam até bater nela, mas já esta resolvido. 
Um amigo defende, mas não em todos os momentos, mas, um melhor amigo sempre defendera com unhas e dentes.

\section{TEXTO 16}

eu já tive essa experiência uma vez quando eu era mais novo, eu acabei discutindo com um colega de aula, ai eu e o colega de aula estamos la discutindo e chegou um outro colega e ceparou a discusão, ja de um colega tambem so que quem ceparou foi eu eles estava discutindo e ai um acabou se irritando e indo para sima do outro colega ai foi que eu entrei e ceparei

\section{TEXTO 17}

Bom eu acho que isso não e amigo e nem melhor amigo porque o amigo não pate separa.

Teve uma ves que um amigo meu estava apanhando ai chegou eu separei a briga mas eles continuaram derepente meu outro amigo deu uma voadora no menino, que acerto o pescosso e o menino fico em coma por 3 messes entao acho que a violencia não leva a nada.

\section{TEXTO 18}

Sim eu já vi uma dessas imagem dois amigos meu brigaram, e não foi legal mas eu, e algumas pessoas separamos, então eu acho que essas imagem quis demonstra que amigos fica em todos momentos que precisamos e amigos verdadeiro não importa o que seja ele esta junto em momento ruim e bons

\section{TEXTO 19}

Bom, não sou muito a favor de qualquer tipo de violência, independente do motivo. $O$ que eu entendi dessa imagem é; que seu melhor amigo te defende com "unhas e dentes" até o final, sempre estara do seu lado independente de qualquer coisa.

Já seu amigo ta ali com você, mais não tem todo aquele "prazer" em te defender. Eu não sou nem contra e nem fazer do que essa imagem nos mostra, é só uma maneira de nos mostrar que a gente tem que saber diferenciar uma coisa da outra

Enfim, foi isso que eu entendi, é isso que eu consegui enxerga. Mas é bem legal essa imagem, não por conta da violência e sim pelo valor que nós temos para um amigo e um melhor amigo.

\section{TEXTO 20}

Eu tenho amigos que ja separaram as minhas brigas e outros que me ajudaram não sou de brigar mas quando tem um amigo meu brigando com alguem, tento separar e acalmar mas se for melhor amigo eu o defendo e protejo porque melhor amigo pra mim significa muito é confiança e companheirismo pra vida toda.

\section{TEXTO 21}

Eu acho bem engraçado o que está escrito nessa foto e concordo com isso, apesar de não gosta muito dos meus amigos se envolverem nas minhas brigas. Melhor amigo chega mesmo dando uma voadora quando ver seu melhor amigo brigando, isso faz parte das melhores amizades. Isso já aconteceu comigo, mas depois fiquei um pouco chatiada com a minha melho amigo. Eu comecei a discuti com uma colega de sala, por besteira. Mais a menina veio com tudo pra cima de mim. A minha melhor amigo não estudava na mesma sala de aula que eu mais na hora da briga ela tava passando pela minha sala, viu 
a menina em cima de mim e partiu pra cima da garota, depois da confusão fiquei chatiado com ela, porque eu não queria que se envolvesse na confusão.

\section{TEXTO 22}

Eu acredito nisso e eu usaria uma blusa asim é eu não gosto disso mas só que já acontecel isso comigo e que eu estava brincando com o menino com o colar dele ai chegou outro menino e falo deixa eu ve ai eu falei não ai ele começou a me da voadora ai eu peguei ele é bati nele e eu não gostei e eu nunca vi ninguem dando voadora e purinquando eu nunca separei uma briga mas sempre que eu brigo separam mas eu brigo porque eles começão eu nunca fui pra cima de ninguém eles que vei para cima.

\section{TEXTO 23}

Na minha opinião essa camiseta fala a realidade de algumas pessoas, eu já vi, meu primo brigo por causa do melhor amigo dele. Mais eu não axo isso legal, porque violência só gera violência, e eu não usaria uma camiseta dessa.

\section{TEXTO 24}

Nunca tive essa experiência mais já vi um amigo meu eu acho ridiculo isso não acho que isso e um ato de amizade sim de vandalismo

\section{TEXTO 25}

Bom, na minha opinião, esta ilustração esta tentando demonstrar, que quando se é apenas amigo, a pessoa meio que tem um certo controle quando um amigo está brigando, mas quando se é melhor amigo o descontrole já é mais dificil de conter, pois você não quer ver uma pessoa querida por você se machucando.

\section{TEXTO 26}

Bom essa camisa, a imagem é engraçada mais pra mim foi engraçado o segundo quadrinho.

I eu nunca passei por isso, porque eu nunca briguei e nunca levei uma nem mais voadora, mas eu já vi umas pessoas dando voadora do seu melhor amigo, mas foi assim de brincadeira.

\section{TEXTO 27}

Eu acho verdade o que está escrito porque em muitas escolas existe principalmente aqui, um amigo do meu amigo estava brigando com um garoto e meu amigo me chamou pra ir ajudar eu não fui ai ele chegou e deu um soco no garoto, o garoto que levou o soco não viu e saiu com o rosto todo roxo.

\section{TEXTO 28}

Amigo so separa e melhor amigo chega dando voadora amigo so anda junto mais melhor amigo fais tudo com você se mete emcrenca vai com voce pra onde for tava eu i um menino brigando ai vem meu primo que e tambem meu melhor amigo ele chego na vuadora nele.

\section{TEXTO 29}

Hum... eu acho que isso è humor como fosse ter graça Algo assim ou para refletir alguma coisa. Como isso na camiseta acontece sempre em escolas.

Eu já passei por isso com meus amigos è bem muita locura. 
TEXTO 30

O que eu acho é que isso é uma atitude de amizade, só que é mais do jovens. E nunca aconteceu isso comigo.

TEXTO 31

Eu acho uma coisa normal até engrassada. Ja aconteceu comigo uma vez mas não tinha amigo para ajudar e brigo muito com meus amigos.

TEXTO 32

Sim, no jogo da Portuguesa X Osasco o goleiro iago chegou dando uma voadora.

Eu ja vi sim, já aconteceu comigo acho puta sacanagem

TEXTO 33

Achei bem legal essa camiseta, eu usaria uma dessa e achei esse gesto meio violento mais amigo é amigo né? E eu faria isso por um amigo.

TEXTO 34

É bem assim, muitas vezes os "melhores amigos" agem de forma super espontânea, como por exemplo na foto.

Pois o "melhor amigo" é como se fosse da família (é mais íntimo) então não precisa agir como uma "personagem".

Eu mesma sou assim, super comportada nas casas das amigas, mas já na casa da minha melhor amiga, já chego deitando no sofá, dizendo que estou com fome, ajudo na faxina... Enfim, como se estivesse em família.

TEXTO 35

Eu ja fis iso porque o menino mim bateu e eu chegei uma vuadora e na briga do meu amigo e ele chega na vuadora

TEXTO 36

$\mathrm{Eu}$ acho que isso acontece muitas vezes, não acho que isso é errado

É um amigo querendo ajudar o outro

Eu usaria uma dessas.

Eu ja vi acontecer isso meu amigo estava brigando com um menino maior que ele e então eu fui ajudar ele.

TEXTO 37

Eu acho isso certo, pra quem é amigo de verdade faz isso pelo outro, tenho um amigo que já fez isso, foi em um campo de futebol, que no término do jogo aconteceu uma briga, e o zagueiro tomou um soco no olho, quando o agressor do outro time deu as costas, o goleiro chegou dando uma voadora nas costas do garoto.

\section{TEXTO 38}

Sim, eu e meu amigo estava indo para o treino de futsal e veio um viado na nossa direção, e ele mexeu com meu amigo, nós correu atraz do viado pra bater nele mais ele era muito rapido, e depois nós foi para o treino. Eu usaria essa camisa sim é de humor muito legal 


\section{Textos dos alunos bolivianos (10 anos na escola brasileira)}

TEXTO 39

$$
\text { Opinião }
$$

Eu acho que quando um amigo aparece e vé que seus amigos brigam ele o separa e quando um e um melhor amigo ele ja o defende o melhor amigo.

\section{Experiencia contado}

Eu ja defendi meu melhor amigo ele estava apanhando de dois adolecentes e quando eu chegei eu o defendi porque eu acho uma injustisa que dois adolecentes batam em um pré adolecente.

TEXTO 40

Bom, acho pessimo, não nunca tive essa experiência na minha vida, pois não gosto de me meter em confusão.

Sim, já vi amigos meus agindo assim, quando via esse tipo de briga me assustava com os atos do melhor amigo.

Seria bom se todos agissem no primeiro quadro, seria mais bom.

Na primeira figura demonstra algo bom já na segunda algo ruim

No meu caso seria bom se não tivesse essa de briga.

\section{TEXTO 41}

Sim eu ja tive uma esperiencia assim um dia na escola um menino tava mechendo com migo ai ele disse que ia brigar comigo na ora do recreio porque ja tinha tocado o sinal. Depois na hora da saida ele veio brigar e nois brigamos mas ele era covarde e cuando ele tava perdendo mandou um de seus amigos me segurar por tras e quando ele queria me dar o primeiro soco o meu melhor amigo veio corendo e deu uma voadora no menino que queria me dar um soco o outro menino me soltou e saio correndo deixando o outro pra tras mas o outro tambem correu e caio machucando a mão. Eu fiquei la com meu amigo comversando por que aquele menino queria me bater.

TEXTO 42

É uma situação violenta de forma mal adequada eu já vi mas não gosto de comentar sobre isso. Faleu!

\section{Textos dos alunos bolivianos (6 anos na escola brasileira)}

TEXTO 43

$$
\text { O-Pinião }
$$

Eu achó e sim Amigo que e com um longa data, de amizade sim chega chegando ajúda sempre que puder. Agora amigo só amigo separa por que so quer um bem pra outro

\section{Experiência é comtando}

Eu já vivi esa emoção mais não e boa por que são dois contra um ou seja eu fiz errado i deveria ter separado por que eu não vou ficar para sempre com ele é ele tem de a comprende a ser consiente. 


\section{TEXTO 44}

Eu acho que é exagerado demais o que está escrito, não é sempre isso que é a relação entre amizades. As vezes a pessoa finge ser seu amigo e tenta te defender e outras vezes sim, separa a briga realmente mas das suas costas pode ser que esteja contra você mas não passei assim nunca, sim magoações. Por causa de bestera eu tive duas amigas, uma era amiga e outra era minha melhor amiga mas para mim era pior inimiga.

Por isso hoje não confiu mas em ninguém Algumas pessoas dissem que são minhas amigas mas quando há briga não me defende, separar até separa mas não existe nem amigo nem amiga apesar de eu ser boliviana não acho pessoa certa nem aqui nem no mundo além da minha família.

\section{Textos dos alunos bolivianos ( 1 ano e meio na escola brasileira)}

\section{TEXTO 45}

Eu acho que quando agen brigar $u$ amigo tem que separar a briga é não chegar e da um voadora pra u outro deve separar e pedir disculpa para cada um.

TEXTO 46

Acho que o da sima ten un desenho do amigo que separa a briga dos dois que estan brigando e o de baixo ten un desenho que e do melhor amigo Que ta defendendo o amigo e bate ao outro

Eu ya fez isso cuando a minha hirman tava brigando con sua amiga Eu fui la e bati en ela 


\section{APÊNDICE 1}

\section{DESCRIÇÃO DA LÍNGUA AIMARÁ \\ (GRASSO, s/d; GRONDIN, 1999)}

- Vogais: possui $a, i$ e $u$, mas adquiriu $e$ e $o$ por influência da língua espanhola haki ou hake (homem)

inchu ou incho (orelha)

- Consoantes:possui 16, sendo as mais comuns as aspiradas ch, th, ph e as explosivas $k, t, p$ achachi (velho)

mankatha (comer)

phakhsi (lua)

inti (sol)

hupa (ele ou ela)

- Posposições: na (de) taqui (para) mpi (com)

hakena (do homem)

haketaqui (para o homem)

hakempi (com o homem)

- Anteposições

Gênero:
hake (homem) marmi (mulher)
urku (macho) qachu (fêmea)
achachi (velho) marmi achachi (velha)
uturunca (tigre) qachu uturunca (tigresa)

Adjetivo:

hachcha (grande) hiskka (pequeno)

achachi (velho) hiskka achachi (velho pequeno)

- Sufixação

Plural: -naca

chacha (homem) chachanaca (homens)

hupa (ele ou ela) hupanaca (eles ou elas)

Desinências Verbais Modo-Temporal e Número-Pessoal

Pretérito perfeito do indicativo: munaña (amar ou querer)

$\begin{array}{ll}\text { mun-away-twa } & \text { (amei ou quis) } \\ \text { mun-away-tawa } & \text { (amaste ou quiseste) } \\ \text { mun-away-iwa } & \text { (amou ou quis) } \\ \text { mun-away-apjj-twa } & \text { (amamos ou quisemos) } \\ \text { mun-away-apjj-tawa } & \text { (amastes ou quisestes) } \\ \text { mun-away-apjj-ewa } & \text { (amaram ou quiseram) }\end{array}$

- Sintaxe da frase: SOV

Cjuchuña munta (Quero faca)

Hachcha haulla munta (Quero peixe grande) 


\section{APÊNDICE 2}

\section{ATIVIDADE MOTIVADORA DA PRODUÇÃO TEXTUAL}

Série:

Nacionalidade:

Se não é brasileiro, há quanto tempo vive no Brasil?

\section{$\underline{\text { Atividade }}$}

A foto abaixo é da estampa de uma camiseta. Escreva o que você acha sobre o que está escrito. Diga também se você já teve uma experiência assim na sua vida ou se já viu algum amigo agindo desse jeito. Se sim, conte como foi.

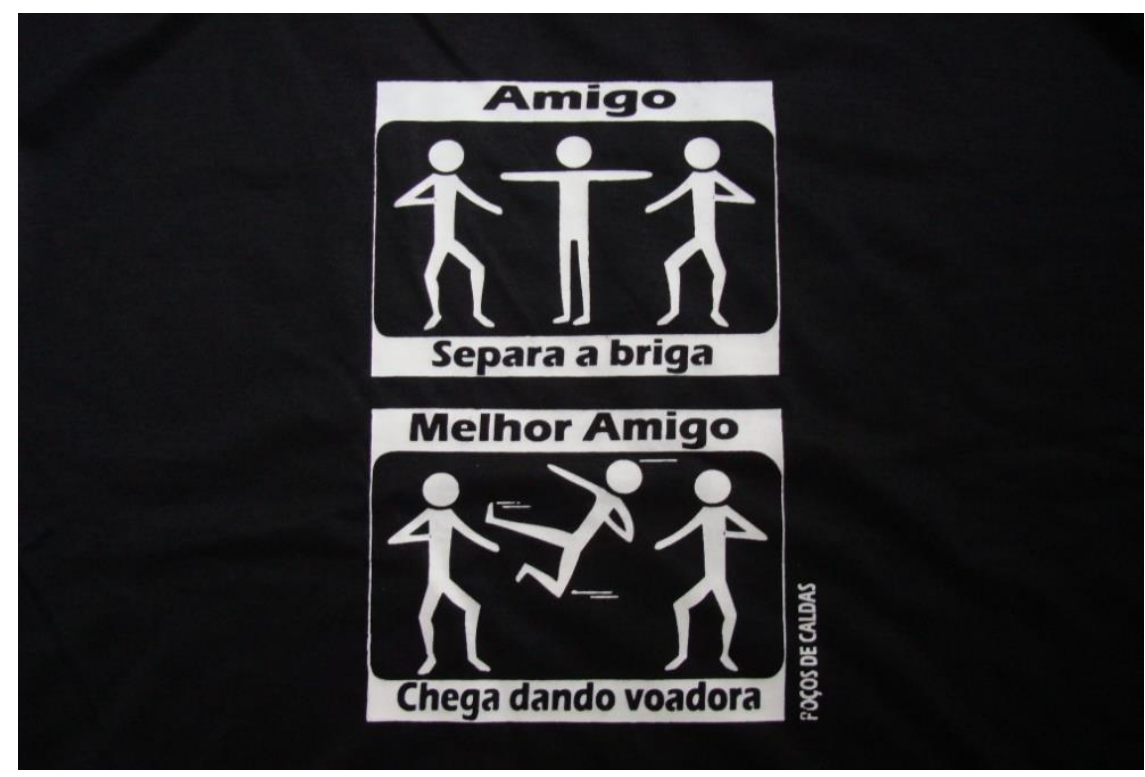




\section{APÊNDICE 3}

\section{PROJETO "EXPEDIÇÃO À BOLÍVIA"}

O projeto "Expedição à Bolívia" foi planejado e desenvolvido como parte de um projeto maior da direção da Escola Municipal Infante Dom Henrique, chamado "Escola Apropriada: Educação, Cidadania e Direitos Humanos”. Iniciado em 2013 e estendido até o presente ano de 2014, o "Escola Apropriada" visou a chamar os alunos imigrantes e/ou descendentes de imigrantes a apropriarem-se da escola, no sentido de se tornarem mais protagonistas nas decisões que os envolviam, buscando refletir e atuar democraticamente a respeito dos conflitos, além de promover integração. Dentro dessa proposta, a direção, envolvida que estava com o tema da presente pesquisa, solicitou que eu colaborasse elaborando o roteiro de uma expedição à Bolívia para levar ao país os alunos da escola que fossem bolivianos ou filhos de bolivianos, bem como os alunos brasileiros e professores, para que pudessem não só reconhecer e compreender diferenças culturais, como também formar ideia própria sobre a Bolívia. Como resultado, imaginou-se que, ao retornarem, os membros da expedição pudessem sensibilizar os colegas sobre a cultura boliviana, multiplicando o que foi visto e aprendido.

A expedição foi custeada pela Secretaria Municipal de Educação, e levou à Bolívia:

- 4 alunos bolivianos

- 4 alunos brasileiros

- 6 professores

- A coordenadora

- O diretor

- Esta pesquisadora

Como localidade, foi escolhida a cidade de La Paz e seu entorno, por ser essa a região de origem da maior parte dos imigrantes bolivianos da cidade de São Paulo, e, consequentemente, dos pais dos alunos da escola também.

Seguem roteiro e objetivos da Expedição: 


\section{ROTEIRO DE EXPEDIČ̃̃O A LA PAZ E ENTORNO}

Objetivos da expedição

- Levar alunos brasileiros e filhos de bolivianos da EMEF Infante D. Henrique, bem como professores e coordenador para conhecer a cidade de La Paz e seu entorno, região de origem da maior parte dos imigrantes bolivianos presentes em São Paulo;

- Explorar com os estudantes bolivianos a região de origem dos seus pais, levando-os a conhecer e reconhecer na população aspectos da sua família e cultura;

- Explorar com os estudantes brasileiros, professores e coordenador a região de origem dos bolivianos presentes na escola e no entorno dela, levando-os a reconhecer e compreender diferenças culturais, bem como a formar ideia própria sobre a Bolívia; e

- Promover a multiplicação e a troca de informações culturais sobre a Bolívia quando do retorno dos viajantes ao ambiente escolar, os quais terão construído sua própria ideia sobre Bolívia, La Paz e seu entorno, habitantes, História, língua, costumes, lugares, comidas, clima.

Datas:

- Saída em 14/10/2014

- Retorno em 19/10/2014

Programação:

- 14/10: Chegada à cidade de La Paz

Adaptação à altitude de 3.600 metros

- 15/10: Visita Plaza Murillo

Praça central de grande movimentação e comércio da cidade, onde se concentram os três poderes

$\underline{\text { Visita ao Museu Nacional de Arte de Bolívia }}$

Abriga obras de arte do período colonial até as últimas décadas do século $\mathrm{XX}$, representadas por artistas europeus e latinoamericanos.

- 16/10: Visita às escolas Ayacucho, Mexico 
Escolas tradicionais de La Paz, onde os alunos puderam conhecer um pouco da rotina escolar boliviana, bem como os alunos e os professores. Visita ao Museu Etnográfico e Folclórico de La Paz

Museu cujo acervo retrata a tecelagem, a cerâmica e as máscaras de carnaval das regiões da Bolívia.

- 17/10: Ida ao Teleférico

Novo sistema de transporte da cidade, cuja finalidade é levar os habitantes e os turistas, mais rapidamente, às áreas mais altas de La Paz, cidade de encostas de vale, com morros íngremes que acrescentam mais altitude à caminhada. O teleférico possui 3 linhas, e uma delas vai até El Alto, cidade próxima que concentra o comércio da região e a maior feira ao ar livre da América do Sul.

\section{$\underline{\text { Visita à Las Brujas }}$}

Área turística e central de La Paz com intensa atividade artesanal típica, como tecelagem, cerâmica e prataria.

- 18/10: Visita às ruínas de Tiwanaku (70 km de La Paz)

Cidade sagrada, localizada a $70 \mathrm{~km}$ de La Paz, que guarda as ruínas de civilização que cultuava o sol, possuía a cruz andina, tinha conhecimentos avançados de astronomia, agricultura e arquitetura. Adoravam animais que eram associados a níveis da existência humana, como o puma, a serpente, a lhama e o peixe, sendo alguns deles também reverenciados mais tarde pelos incas, o que faz com que arqueólogos afirmem que a civilização de Tiwanaku está nas origens da inca.

Visita ao lago Titicaca

Lago de montanha resultante da formação da cordilheira. É importante fonte de água doce, peixe e lazer para os habitantes da região, além de ser atrativo para turistas de todo o mundo. O lago esteve na origem da civilização de Tiwanaku justamente por ser reserva de água doce.

- 19/10: Retorno ao Brasil

O roteiro foi elaborado de modo proporcionar informações sobre as origens (Tiwanaku), os hábitos (Museu Etnográfico e Folclórico), as artes (Museu Nacional de Arte), o turismo (Las Brujas, lago Titicaca), o cotidiano (Plaza Murillo, o teleférico) e a 
educação (escolas Ayacucho e Mexico). Optou-se sempre que possível por fazer os deslocamentos a pé dentro da cidade, o que favoreceu a observação da arquitetura, do trânsito, das pessoas, dos seus idiomas.

Os alunos fizeram anotações durante toda a viagem, para, ao final, elaborar um relatório. Abaixo o relatório de uma das alunas bolivianas membro da expedição. $\mathrm{O}$ texto foi transcrito conservando-se a grafia original. A aluna não participou escrevendo os textos do corpus da pesquisa.

\section{$\underline{\text { Relatório da Expedição }}$}

\section{Chegada a Bolívia}

Quando chegamos em La paz não deu pra acreditar que estávamos lá!, tipo não caiu a ficha. Bem me lembro que eu fiquei meio mal mais foi por causa da altitude. Bem chegamos a noite no hotel e não deu pra aproveitar nada nesse dia, então fomos descarregar nossas malas e ir jantar.

\section{$\underline{1^{\circ} \mathrm{Dia}}$}

No nosso primeiro dia de expedição fomos visitar Plaza Murillo. Seu nome é uma homenagem a Pedro Domingo Murillo patriota boliviano e precursor na independência do País, é também a Plaza e o Marco Zero a partir do qual se medem as distâncias no país, situase a mais de 3600 metros de altitude.

Na Plaza Murillo, localiza-se o Parlamento da Bolívia e o Palacio do Governo.

"Foi muito bom conhecer a Plaza murillo, pois eu não conhecia, gostei bastante um lugar sensacional" diz Sandy.

Segunda parada Museu Nacional de Artes uma das mais importantes isntituições culturais de La Paz.

O museu possui coleções de pinturas, esculturas e artegrafica.

"No museu o que mais me chamou a atenção foi as pinturas da guerra, também fiquei impressionada com as pinturas que retratam as varias paisagens da Bolivia". Diz Sonia.

"Eu gostei bastante porque eu nunca tinha visto pinturas de artistas paceños e isso que me chamou mais a atenção" diz Alvaro.

"Gostei da parte que a Moça fala sobre as guerras" diz Jessica.

Depois de ir ao museu almoçamos e fomos a um debate com o secretario de educação de La Paz. 
La o diretor e o secretario debateram alguns problemas e questões escolares tanto brasileiras, quanto bolivianas.

1-Alimento escolar

2-Uniforme

3-Infraestrutura

Muitas coisas mais se debateram, além disso o Diretor fala sobre o projeto e das escolas públicas.

"Foi bom a reunião e saber como são as escolas e a educação boliviana vi muitos pontos positivos, discutidos na reunião" diz Paulo

$\underline{2^{\circ} \mathrm{Dia}}$

Visitamos 2 escolas a primiera escola foi a escola "Nueva Mexico", la a diretora falou sobre a educação e sobre o projeto que a escola esta reaizando que é "Valores que não se podem perder”. Visitamos as salas de aula.

$\mathrm{Na} 2^{\mathrm{a}}$ escola "E. U. Santa Rosa la Florida" onde nos também conversamos com a diretora e alunos.

"Foi muito bom ir as duas escolas, mais o que me chamou mais a atenção foi que todos vão de uniforme e a educação, tipo todos se levantam e dizem bom dia professor" diz Mikaela.

Proxima Parada Museu Folclorico e Etnografico da Bolivia. Esse museu tem um pedacinho de toda a Bolivia.

1- Tecelagem, estração de lã, as ervas da medicina, frutas que tem cores, vestimentos típicos.

2- Quadros.

Vimos vários quadros de paisagens que mostram as diferentes culturas e costumes na Bolivia.

\section{3- Mascaras}

As mascaras atualmente são bem usadas na Bolivia. As mascaras representam os profundos rituais relacionados a seus antepassados (Auqui Auqui, Achachila), como deuses e seres místicos (diabo, Jukumanis e danzatis). As mascaras tem caracteristicas tanto urbanas como rurais.

4- Idiomas

Bom nesse setor eu gostei bastante porque fala sobre os idiomas de nossos antepassados. Ex. Aymara e Quechua.

"El lenguaje es la utilizacion de las palavras para exponer las ideas" 


\section{5- Ceramica}

$\mathrm{Na}$ cerámica vi bastante coisas antigas como vasos, taças, estatuas e ate escrituras.Vi também como se faz coisas com aceramica.

"Gostei demais de tudo mesmo do que mais gostei foi das mascaras, muito lindas e bem feitas" diz Sandy

"Foi legal gostei se vou viajar denovo a La Paz, vou voltar para revisitar o museu porque gostei muito mesmo", diz Jessica.

$\underline{3^{\circ} \mathrm{Dia}}$

Pra mim um dos dias mais esperado. Eu simplesmente amei o teleférico quando você sobe da pra ver toda La Paz inteira a vista e maravilhosa. E também fomos ao Mirador onde se vê a montanha do Illimani. Depois disso almoçamos e fomos as compras.

"Foi um lindo dia o teleférico resumindo em uma palavra "MARAVILHOSO" espero ver mais vezes", diz Sonia.

"O mirador é muito lindo gostei de ter ido" diz Jessica.

"Fotos, Fotos tirei varias fotos gostei do teleférico" diz Mikaela $\underline{4^{\circ} \mathrm{Dia}}$

Ouvi desde de pikena que TIWANAKU e muito lindo lindo, pois eu vi com meus proprios olhos. Tiwanaku e um sitio arqueológico que mais antes os incas moravam. Gostei bastante, mas o que eu me facionei foi com a porta do Sol e os monólitos. Tudo tão maravilhoso que me deixou encantada.

Depois de Almoçar fomos ao Lago Titicaca. Um dos lagos mais profundos do Mundo. Gostei bastante pois eu nunca havia ido ao logo.

"Esse lago e muito lindo mesmo, ele e paradiciaco" diz Paulo

Fernanda Mikaela

"Foi bom ter vindo essa experiência vou levar em minhas memórias, gostei de todos os lugares que nos visitamos e a Bolivia que me falavam que era subdesenvolvida que tudo era antigo, não é a Bolivia que eu visitei”

Paulo Sergio

"Foi muito Bom ter conhecido a Bolivia La Paz, os lugares que nos fomos foi legal gostei mais do Museu folclorico Etnografico.

Jessica 
"Bom eu nasci na Bolívia (La Paz) mais nunca tive oportunidade de visitar tantos lugares assim, foi muito lindo ter ido com a escola e os professores, gostei mais do Museu Nacional de Arte"

Sandy

"Embora eu tenha passado mal me diverti bastante com meus colegas, foi muito legal ter ido, conhecer um pouco de cada pedacinho de La Paz, gostei mais das escolas porque eu me senti em casa"

Alvaro

"Gostei de ter ido em Tiwanaku, pois minha familia mora por la, Gostei demais da Expedição de tudo o que eu aprendi, não so nos livros como em poder ir la e sentir toda aquela emoção"

Sônia

Gostei muito porque mesmo eu sendo descendente nunca havia conhecido o Tihuanaco ou lago titi-caca so tinha houvido falar e conhecer isso ao vivo em cores é uma emoção inesplicavel, posso até dizer que foi a melhor viagem na minha vida!! Só tenho a agradecer pela oportunidade!..

Feito por Aline 